\title{
Game mammals of the Caatinga biome
}

Rômulo Romeu Nóbrega Alves ${ }^{1,2 *}$, Anderson Feijó $24,5,5$, Raynner Rilke Duarte Barbozal,2, Wedson Medeiros Silva Souto ${ }^{2,3}$, Hugo Fernandes-Ferreira2 ${ }^{2}$ Pedro Cordeiro-Estrela ${ }^{2,4}$, Alfredo Langguth ${ }^{2,4}$

\begin{abstract}
Mammals stand out among the main game animals of the world, being exploited by human beings for different ends, and being important for the subsistence of several communities. In semiarid environments, as in the Brazilian Caatinga biome, wild mammals have been exploited by the local human population, including endangered species. In this scenario, beyond biological research of the exploited animals, ethnozoological studies are important for supporting plans for the sustainable management and conservation strategies for the mammalian fauna of the semiarid landscape. This study aims to contribute to new research into the ethnomammalogy of this specific region. It provides a catalogue of the mammals and their ethnozoological importance, including a brief characterization of game mammals of the morphoclimatic domain of the Caatinga. The results show that at least 41 species of wild mammals interact with the population that lives in the semiarid region, as sources of products that can be used for the following purposes: food (31 species), medicinal (38 species), ornamental or decorative purposes (23 species), in magical/religious practices (31 species), and as pets (24 species). Twenty-five species are hunted because of concerns over personal safety or predation on livestock and pests. Among the recorded mammals, $13(31.7 \%)$ are listed in some threatened category (Critically endangered, Endangered or Vulnerable). Hunting is one of the main factors contributing to this situation, which provides evidence that conservation strategies should consider the associated human needs, integrating cultural aspects of the local populations, and ecological aspects associated with the biodiversity of the region.
\end{abstract}

Keywords: Animal uses, Bushmeat, Ethnozoology, Hunting, Medicinal animals.

\section{INTRODUCTION}

Humans and wild mammals interact in many different ways (Happold 1995), culminating in relations that vary according to specific human cultures and that are reflected in negative or positive effects on the wild mammals that are involved (Alves 2012; Alves et al. 2009a, 2013c;
Bodmer et al. 1997; Happold 1995; Leopold 1959; Monks 2005; Uribe and Arita 1998). As well as being used for food, mammals are utilized in creating artefacts such as adornments, fuel, medicines and are used as sources of beauty and inspiration, and divinity symbols (Alves 2012; Alves et al. 2013a,c; Ho 2005; Perrin et al. 2008; Ripple and

1 Departamento de Biologia, Universidade Estadual da Paraíba, Av. das Baraúnas, 351, Campus Universitário, Bodocongó, 58109-753, Campina Grande-PB, Brazil.

2 Programa de Pós-Graduação em Ciências Biológicas (Zoologia), Universidade Federal da Paraíba, Campus Universitário, 58051-900, João Pessoa, PB, Brazil

3 Universidade Federal do Piauí (UFPI), ZUCON (Laboratório de Zoologia, Uso e Conservação da Fauna), Departamento de Biologia, Campus Ministro Petrônio Portella, 64049-550, Teresina, PI, Brazil.

4 Laboratório de Mamíferos, Departamento de Sistemática e Ecologia da Universidade Federal da Paraíba, Campus Universitário, 58051-900, João Pessoa, PB, Brazil

5 Integrative Research Center, Field Museum of Natural History, 60605, Chicago, IL, United States of America

* E-mail adresses: RRNA (romulo_nobrega@yahoo.com.br),AF (andekson@gmail.com), RRDB (raynner@live.com),WMSS (wedson@ live.com), HFF (hugofernandesbio@gmail.com),PCE (pedrocometa@gmail.com), AL (boninomvd@hotmail.com) 
Perrine 1999). On the other hand, some mammals regarded as vermin or plagues have also been persecuted or "controlled", based on concerns with personal safety, disease transmission, or predation on livestock and pets (Garcia-Alaniz et al. 2010; Hausser et al. 2009; Johnson et al. 2001; Kideghesho 2008; Mendonça et al. 2011; Treves et al. 2006). This ambiguity in the interaction between people and animals is common across different human cultures and depends on the species that are involved (Alves 2012; Alves and Souto 2015; Antonites and Odendaal 2004).

Considering the important role which mammals play in the subsistence of the human population (Alves et al. 2013a; IUCN 2015; Redford et al. 2011), these animals have been the focus of human attention for a long time (Redford et al. 2011). In various regions of the world, researchers confirm the importance of the mammal hunt, especially in humid tropical regions (Bodmer et al. 1997; Happold 1995; Ojasti 1984, 1997, 2000; Peres and Nascimento 2006; Robinson and Redford 1991; Silvius et al. 2004; Souza and Alves 2014). Although they are less diverse than in humid tropical forests, the mammal fauna of the semiarid environments have always been exploited by local human populations, being in some cases one of the main reasons why many species become endangered (Alves et al. 2009a).

On the Brazilian Caatinga, one of the major areas of semi-arid environment in the Neotropical region, mammals constitute the main game resource (together with the birds) (Barboza et al. 2016; Mendonça et al. 2016), even though Caatinga's mammal fauna composition was, for a long time, considered poor compared to that of the Atlantic Forest or the Amazonian Forest. Its composition was also seen as a sum of subsets from these biomes as well as from the Cerrado (Mares et al. 1985; Streilein 1982). In 1989, the number of registered Caatinga's mammalian species was 80 (Mares et al. 1981) and the biome was characterized by its low diversity and low endemism. Later, Fonseca et al. (1996) elevated this number to 101; Oliveira et al. (2003) listed 148 mammals, and recently Carmignotto et al. (2012) raised this number to 153 . Many of these species have interacted with locals, because of their utility value and/or due to conflicting relations with man (Alves et al. 2009a; Melo et al. 2014b; Mendonça et al. 2011).

In this context, ethnozoological studies are important to subsidize sustainable wildlife management plans and conservation strategies for the mammalian fauna on the semi-arid region of Brazil. This study aims to elaborate a catalogue of the game mammals of ethnozoological importance in the Caatinga together with a brief characterization of the species. Finally, we discuss the mammals' interactions with the local populations and its socio-economic, cultural and conservationist implications.

\section{METHODS}

\section{Study area}

In Brazil, the word Caatinga is used to designate a large geographic area comprising a variety of diferent types of vegetation. It is also used to name the semiarid region that occupies the largest portion of the northeastern region of Brazil. Its temperature, rainfall regimes and edaphic properties have determined the development of a vegetation dominated by seasonally dry tropical forests (Albuquerque et al. 2012). The Caatinga is a biome composed predominantly of xerophytic, woody, thorny, and deciduous phytophysiognomies (Costa et al. 2007; Sampaio 1995), with a hot and dry climate (Veloso et al. 1991), occupying more than $750,000 \mathrm{~km}^{2}$. It is a semiarid region with drought periods that can last up to 11 months per year (Ab'Saber 1974). The Caatinga's unique climatic conditions, have provided adaptive singularities in its biodiversity, driving species to evolve specific physiologies and reproductive behaviours (Rodrigues 1996; Vieira et al. 2009).

The seasonally dry tropical forest which are the dominant type of vegetation in the semiarid region of Brazil can vary considerably (Andrade-Lima 1982; Pereira Filho and Montingelli 2011; Tabarelli and Santos 2004) from forests composed mostly of spiny trees, 6 to $10 \mathrm{~m}$ tall, often with a ground-layer of small deciduous shrubs and an- 
nual herbs, predominantly Leguminosae, to deciduous woodlands of lower stature, with a high proportion of shrubs and sub-shrubs and the presence of numerous cacti, bromeliads and Euphorbiaceae (Andrade-Lima 1982; Bigarella et al. 1975; Pereira Filho and Montingelli 2011; Tabarelli and Santos 2004).

Within the semiarid Caatinga, there are several humid forest remnants associated to higher altitude plateaus and mountain ranges $(600-1200 \mathrm{~m})$, locally known as Brejos de Altitude (Upland forests). These humid forests have distinct phytophysiognomies depending on predominance of Atlantic forest, Amazonia or Caatinga species (Andrade-Lima 1982; Bigarella et al. 1975; Lins 1989; Tabarelli and Santos 2004).

The Caatinga has been described as harbouring relatively few animal species and having low numbers of endemic species (Andrade-Lima 1982; Prance 1987; Vanzolini et al. 1980). Some recent studies, however, have demonstrated the importance of the region for the conservation of a significant component of Brazilian biodiversity (Leal et al. 2005). The number of known mammalian species in the Caatinga $(n=153)$ is greater than that of the Pantanal - Swampland ( $n=113$; Meserve 2007) or the Grande Chaco ( $n=102$; Meserve 2007) but it is less than that of the Amazon Forest $(n=350$; Meserve 2007), the Atlantic Forest ( $n=261$; Myers et al. 2000), and the Cerrado ( $n=199$; Klink and Machado 2005). Despite recent advances in our knowledge of the mammals of the Caatinga, many geographical areas of the biome have not yet been studied.

Additionally, the Brejos de Altitude have served as refuges in the midst of an arid region, and presents, relatively, a greater abundance and diversity of animal species, including some endemic and threatened species (Andrade and Lins 1964; Borges-Nojosa and Caramaschi 2003; Theulen 2004).

In the Caatinga region, hunting plays an important socioeconomic role and the meat of wild mammals (and others vertebrate groups) constitutes an important protein source for several rural and urban communities, especially during the seasonal drought periods, when crops become scarce and domestic animals are decimated by starvation and thirst (Alves et al. 2009a; Barboza et al. 2016; Fernandes-Ferreira et al. 2012; Melo et al. 2014b; Mendonça et al. 2016).

\section{Data Collection}

Ethnozoological information on mammals interacting with local people within the Caatinga was obtained from published literature, unpublished thesis and dissertations, as well as from reports available at international online databases such as Science Direct (www.sciencedirect.com), Google Scholar, Scopus (www.scopus.com) and Web of Science (www.isiknowledge.com) using the following search terms: mammals+uses+Caatinga - mammals+uses+Brazilian semiarid region - mammals+ethnozoology+Caatinga - mammals+ethnozoology+Brazilian semiarid region mammals+hunting+Caatinga and mammals+hunting+ Brazilian semiarid region. Only taxa that could be identified to the species level were included in the database, and the scientific nomenclature of the suprageneric taxa follows the world list of mammals (Wilson and Reeder 2005), except for some recent changes. The conservation status of the mammalian species follows IUCN (2015) and the Brazilian Red List (Ministério do Meio Ambiente 2014).

The database created contains information on the species of mammals, their uses and their ways of interacting with people. In this study, we consider as "game mammals" all species that are hunted for different purposes, whether as a product source used by humans (e.g. food, medicine and magical/ religious practices, ornamental or decorative purposes), captured alive to use as pets and even those species that are hunted due of concerns with personal safety or predation on livestock and pets, which we named as conflicting relationships.

\section{Description of the recorded species}

Descriptions of the recorded game mammals were based on specimens housed in scientific collections and on the available data in the literature mentioned throughout the text. We visited the mammal collections of the Universidade Federal da Paraíba (UFPB), Universidade Federal 
de Pernambuco (UFPE), Museu Nacional da Universidade Federal do Rio de Janeiro (MN), and the Museu de Zoologia da Universidade de São Paulo (MZUSP).

\section{RESULTS}

Our results revealed that the human population which inhabit the semiarid region of Brazil has established ethnozoological interactions with at least 41 wild mammal species. If we consider only the large and medium-sized mammals, we see that practically all the species in this region are somehow connected with interactions (harmonious and/or conflicting) with local inhabitants. As happens in other Brazilian biomes, the mammals are used for different purposes by the local population, or they are the target of conflicting relationships, both factors that contribute to their capture or killing (Hanazaki et al. 2009; Lopes and Ferrari 2000; Mesquita and Barreto 2015; Ojasti 1997; Souza and Alves 2014; Torres et al. 2009).
The largest number of species was recorded within the Carnivora (12 species) followed by Rodentia (8), Cingulata (6), Primates (4), Artiodactyla (4), Pilosa (3), Didelphimorphia (2), Perissodactyla (1) and Lagomorpha (1) (Table 1). The species listed provide products that can be used for the following purposes: food (31 species), medicinal (38 species), ornamental or decorative purposes (23 species), in magical/religious practices (31 species), and pets (24 species). Additionally, 25 species regarding as pests have been persecuted or "controlled" because of concerns with personal safety or predation on livestock and pets. The majority of species $(n=40)$ may have multiple uses and they are also conflict target, a situation that motivates their slaughter or capture.

The general features of the recorded mammals and respective ethnozoological notes are provided in the following section. The external measurements were taken from Feijó and Langguth (2013) and (Oliveira and Langguth 2004).

Table 1. Game mammals species, their respective uses, conflicting characteristics in the semiarid region of Brazil, and conservation status.

\begin{tabular}{|c|c|c|c|c|c|c|c|}
\hline \multirow{2}{*}{ Family/ Species / Vernacular name } & \multicolumn{5}{|c|}{$\begin{array}{l}\text { Uses and Conflicting } \\
\text { relationships }\end{array}$} & \multirow{2}{*}{ IUCN } & \multirow{2}{*}{$\begin{array}{l}\text { Brazil } \\
\text { Red List }\end{array}$} \\
\hline & $\mathbf{F}$ & $\mathbf{M}$ & MR & $\mathbf{P}$ & O CR & & \\
\hline \multicolumn{8}{|l|}{ ORDER CINGULATA } \\
\hline \multicolumn{8}{|l|}{ Family Dasypodidae Gray, 1825} \\
\hline $\begin{array}{l}\text { Dasypus novemcinctus Linnaeus, } 1758 \text { - Nine-banded } \\
\text { armadillo, Tatu-galinha, Tatu-verdadeiro }\end{array}$ & $\mathbf{\square}$ & $\mathbf{\square}$ & $\mathbf{\square}$ & - & - & LC & $\mathrm{NI}$ \\
\hline $\begin{array}{l}\text { Dasypus septemcinctus Linnaeus, } 1758 \text { - Brazilian } \\
\text { Lesser Long-nosed Armadillo, tatu-mirim ou tatu-china }\end{array}$ & $\mathbf{\square}$ & $\mathbf{\square}$ & - & - & - & LC & $\mathrm{NI}$ \\
\hline $\begin{array}{l}\text { Euphractus sexcinctus (Linnaeus, 1758) - Yellow } \\
\text { armadillo, Tatu-peba, Peba }\end{array}$ & $\mathbf{\square}$ & $\mathbf{\square}$ & घ & घ & - & LC & $\mathrm{NI}$ \\
\hline $\begin{array}{l}\text { Tolypeutes tricinctus (Linnaeus, 1758) -Three-banded } \\
\text { armadillo, Tatu-bola }\end{array}$ & $\mathbf{\square}$ & घ & 口 & - 1 & - & VU & EN \\
\hline $\begin{array}{l}\text { Cabassous tatouay (Desmarest, 1804) - Greater Naked- } \\
\text { tailed Armadillo, Tatu-de-rabo-mole, Tatu-rabo-de-couro, } \\
\text { Tatu-china }\end{array}$ & $\mathbf{\square}$ & $\mathbf{\square}$ & $\mathbf{\square}$ & & $\mathbf{\square}$ & LC & $\mathrm{NI}$ \\
\hline $\begin{array}{l}\text { Priodontes maximus (Kerr, 1792) - Giant armadillo, } \\
\text { tatu-canastra }\end{array}$ & $\mathbf{\square}$ & $\boldsymbol{\square}$ & $\mathbf{\square}$ & & $\mathbf{\square}$ & VU & VU \\
\hline
\end{tabular}




\begin{tabular}{|c|c|c|c|c|c|c|c|c|}
\hline \multirow{2}{*}{ Family/ Species / Vernacular name } & \multicolumn{6}{|c|}{$\begin{array}{l}\text { Uses and Conflicting } \\
\text { relationships }\end{array}$} & \multirow{2}{*}{ IUCN } & \multirow{2}{*}{$\begin{array}{l}\text { Brazil } \\
\text { Red List }\end{array}$} \\
\hline & $\mathbf{F}$ & $\mathbf{M}$ & MR & $\mathbf{P}$ & 0 & CR & & \\
\hline \multicolumn{9}{|l|}{ ORDER DIDELPHIMORPHIA } \\
\hline \multicolumn{9}{|l|}{ Family Didelphidae Gray, 1821} \\
\hline $\begin{array}{l}\text { Didelphis marsupialis Linnaeus, } 1758 \text { - White-eared } \\
\text { opossum, timbu-de-orelha-branca }\end{array}$ & घ & घ & $\mathbf{\square}$ & & & घ & LC & $\mathrm{NI}$ \\
\hline $\begin{array}{l}\text { Didelphis karkinophaga Zimmermann, } 1780 \text { - Black- } \\
\text { eared opossum, timbu-de-orelha-preta }\end{array}$ & - & घ & घ & & & $\mathbf{\square}$ & LC & $\mathrm{NI}$ \\
\hline \multicolumn{9}{|l|}{ ORDER PILOSA } \\
\hline \multicolumn{9}{|l|}{ Family Myrmecophagidae Gray, 1825} \\
\hline $\begin{array}{l}\text { Tamandua tetradactyla (Linnaeus, 1758) - Southern } \\
\text { Tamandua, Tamanduá-de-colete, Tamanduá-mirim }\end{array}$ & $\mathbf{\square}$ & $\mathbf{\square}$ & घ & घ & $\mathbf{\square}$ & $\mathbf{\square}$ & LC & $\mathrm{NI}$ \\
\hline $\begin{array}{l}\text { Myrmecophaga tridactyla Linnaeus, } 1758 \text { - Giant } \\
\text { Anteater, Tamanduá-bandeira }\end{array}$ & - & - & घ & - & घ & घ & VU & VU \\
\hline \multicolumn{9}{|l|}{ Família Bradypodidae Gray, 1821} \\
\hline $\begin{array}{l}\text { Bradypus variegatus Schinz, } 1825 \text { - Brown-throated } \\
\text { Sloth, Preguiça-de-Garganta-Marrom }\end{array}$ & $\boldsymbol{\square}$ & घ & $\mathbf{\square}$ & - & & & LC & $\mathrm{NI}$ \\
\hline \multicolumn{9}{|l|}{ ORDER PRIMATES } \\
\hline \multicolumn{9}{|l|}{ Family Cebidae Bonaparte, 1831} \\
\hline $\begin{array}{l}\text { Cebus (Sapajus) libidinosus (Spix, 1823)- Bearded } \\
\text { capuchin, Macaco-prego }\end{array}$ & - & - & & घ & & & LC & $\mathrm{NI}$ \\
\hline $\begin{array}{l}\text { Callithrix jacchus Linnaeus, } 1758 \text { - White tuffed ear; } \\
\text { Sagüi-de-tufo-branco }\end{array}$ & - & घ & & घ & & & LC & $\mathrm{NI}$ \\
\hline \multicolumn{9}{|l|}{ Family Atelidae Gray, 1825} \\
\hline $\begin{array}{l}\text { Alouatta belzebul Elliot, } 1912 \text { - Red-handed Howler } \\
\text { Monkey, Guariba-de-mãos-ruivas }\end{array}$ & & घ & घ & & & & VU & VU \\
\hline \multicolumn{9}{|l|}{ Family Pitheciidae Mivart, 1865} \\
\hline $\begin{array}{l}\text { Callicebus barbarabrownae Hershkovitz, } 1990 \text { - Barbara } \\
\text { Brown's Titi, Blond Titi Monkey, Guigó }\end{array}$ & & & & घ & & & CE & CE \\
\hline \multicolumn{9}{|l|}{ ORDER LAGOMORPHA } \\
\hline \multicolumn{9}{|l|}{ Family Leporidae Fischer, 1817} \\
\hline $\begin{array}{l}\text { Sylvilagus brasiliensis (Linnaeus, 1758) - Forest Rabbit, } \\
\text { Tapeti, Coelho }\end{array}$ & & & & & & & LC & $\mathrm{NI}$ \\
\hline \multicolumn{9}{|l|}{ ORDER CARNIVORA } \\
\hline \multicolumn{9}{|l|}{ Felidae Fischer, 1817} \\
\hline $\begin{array}{l}\text { Leopardus pardalis (Linnaeus, 1758) - Ocelot, } \\
\text { Jaguatirica }\end{array}$ & & घ & $\square$ & घ & $\square$ & $\square$ & LC & VU \\
\hline $\begin{array}{l}\text { Leopardus tigrinus (Schreber, 1775) - Little Spotted } \\
\text { Cat, Oncilla, Gato-do-mato-pintado-pequeno }\end{array}$ & & घ & घ & घ & घ & घ & VU & EN \\
\hline $\begin{array}{l}\text { Leopardus wiedii (Schinz, 1821) - Margay, } \\
\text { Gato-maracajá }\end{array}$ & & घ & घ & घ & घ & घ & NT & VU \\
\hline
\end{tabular}




\begin{tabular}{|c|c|c|c|c|c|c|c|c|}
\hline \multirow{2}{*}{ Family/ Species / Vernacular name } & \multicolumn{6}{|c|}{$\begin{array}{l}\text { Uses and Conflicting } \\
\text { relationships }\end{array}$} & \multirow{2}{*}{ IUCN } & \multirow{2}{*}{$\begin{array}{l}\text { Brazil } \\
\text { Red List }\end{array}$} \\
\hline & $\mathbf{F}$ & M & MR & $\mathbf{P}$ & 0 & CR & & \\
\hline $\begin{array}{l}\text { Puma concolor (Linnaeus, 1771) - Cougar, Suçuarana, } \\
\text { Onça-parda }\end{array}$ & & घ & $\mathbf{\square}$ & - & - & $\mathbf{\square}$ & LC & VU \\
\hline $\begin{array}{l}\text { Puma yagouaroundi (É. G. Saint-Hilaire, 1803) - } \\
\text { Jaguarundi, Gato-mourisco, Gato-azul }\end{array}$ & & घ & - & - & घ & - & LC & VU \\
\hline Panthera onca (Linnaeus, 1758) - Jaguar, Onça-pintada & & घ & घ & घ & $\mathbf{\square}$ & $\mathbf{\square}$ & NT & VU \\
\hline \multicolumn{9}{|l|}{ Family Canidae Fischer, 1817} \\
\hline $\begin{array}{l}\text { Cerdocyon thous (Linnaeus, 1766) - Crab-eating fox, } \\
\text { Raposinha, Cachorro-do-mato }\end{array}$ & & घ & $\mathbf{\square}$ & - & & $\mathbf{\square}$ & LC & $\mathrm{NI}$ \\
\hline \multicolumn{9}{|l|}{ Family Mustelidae Fischer, 1817} \\
\hline Eira barbara (Linnaeus, 1758) - Tayra, Papa-mel & ఐ & & & & - & - & LC & $\mathrm{NI}$ \\
\hline Galictis cuja (Molina, 1782) - Lesser grison, Furão & & घ & & $\mathbf{\square}$ & $\mathbf{\square}$ & $\mathbf{\square}$ & LC & $\mathrm{NI}$ \\
\hline \multicolumn{9}{|l|}{ Family Mephitidae Bonaparte, 1845} \\
\hline $\begin{array}{l}\text { Conepatus amazonicus (Lichtenstein, 1838) - Striped } \\
\text { hog-nosed skunk, Gambá,Ticaca, Jeritataca }\end{array}$ & घ & घ & & घ & - & $\mathbf{\square}$ & NA & NA \\
\hline \multicolumn{9}{|l|}{ Family Procyonidae Gray, 1825} \\
\hline $\begin{array}{l}\text { Nasua nasua (Linnaeus, 1766) - Brown-nosed } \\
\text { coati, Quati }\end{array}$ & 匹 & $\mathbf{\square}$ & - & - & - & & LC & $\mathrm{NI}$ \\
\hline $\begin{array}{l}\text { Procyon cancrivorus (G. Cuvier, 1798) - Crab-eating } \\
\text { raccoon, Guaxinim, Mão-pelada }\end{array}$ & & घ & - & घ & घ & $\mathbf{\square}$ & LC & $\mathrm{NI}$ \\
\hline \multicolumn{9}{|l|}{ ORDER PERISSODACTYLA } \\
\hline \multicolumn{9}{|l|}{ Family Tapiridae Gray, 1821} \\
\hline Tapirus terrestris (Linnaeus, 1758) - Brazilian Tapir, Anta & - & $\mathbf{\square}$ & $\mathbf{\square}$ & & $\mathbf{\square}$ & & VU & VU \\
\hline \multicolumn{9}{|l|}{ ORDER ARTIODACTYLA } \\
\hline \multicolumn{9}{|l|}{ Family Tayassuidae Palmer, 1897} \\
\hline $\begin{array}{l}\text { Pecari tajacu (Linnaeus, 1758) - Collared peccaries, } \\
\text { Cateto }\end{array}$ & 匹 & घ & - & & & $\mathbf{\square}$ & LC & $\mathrm{NI}$ \\
\hline $\begin{array}{l}\text { Tayassu pecari (Link, 1795) - White-lipped peccaries, } \\
\text { Queixada }\end{array}$ & घ & घ & - & & & घ & VU & VU \\
\hline \multicolumn{9}{|l|}{ Family Cervidae Goldfuss, 1820} \\
\hline $\begin{array}{l}\text { Mazama gouazoubira (Fischer, 1814) - Gray Brocket, } \\
\text { veado catingueiro }\end{array}$ & घ & घ & घ & घ & घ & घ & LC & $\mathrm{NI}$ \\
\hline $\begin{array}{l}\text { Mazama americana (Erxleben, 1777) - Red Brocket, } \\
\text { Veado Mateiro }\end{array}$ & घ & घ & - & $\mathbf{\square}$ & घ & $\mathbf{\square}$ & DD & $\mathrm{NI}$ \\
\hline \multicolumn{9}{|l|}{ ORDER RODENTIA } \\
\hline \multicolumn{9}{|l|}{ Family Caviidae Fischer, 1817} \\
\hline $\begin{array}{l}\text { Hydrochoerus hydrochaeris (Linnaeus, 1766) - } \\
\text { Capybara, Capivara }\end{array}$ & घ & - & - & & घ & $\mathbf{\square}$ & LC & $\mathrm{NI}$ \\
\hline
\end{tabular}




\begin{tabular}{|c|c|c|c|c|c|c|c|c|}
\hline \multirow{2}{*}{ Family/ Species / Vernacular name } & \multicolumn{6}{|c|}{$\begin{array}{l}\text { Uses and Conflicting } \\
\text { relationships }\end{array}$} & \multirow{2}{*}{ IUCN } & \multirow{2}{*}{$\begin{array}{l}\text { Brazil } \\
\text { Red List }\end{array}$} \\
\hline & $\mathbf{F}$ & M & MR & $\mathbf{P}$ & 0 & CR & & \\
\hline $\begin{array}{l}\text { Galea spixii (Wagler, 1831) - Spix's Yellow-toothed Cavy, } \\
\text { Preá }\end{array}$ & - & घ & & घ & & घ & LC & $\mathrm{NI}$ \\
\hline Kerodon rupestris (Wied, 1820) - Rock Cavy, Mocó & $\mathbf{\square}$ & $\mathbf{\square}$ & $\mathbf{a}$ & & & - & LC & VU \\
\hline \multicolumn{9}{|l|}{ Family Echimyidae Gray, 1825} \\
\hline $\begin{array}{l}\text { Thrichomys laurentiusThomas, } 1904 \text { - Common Punare, } \\
\text { Punaré }\end{array}$ & - & & & & & $\mathbf{\square}$ & LC & $\mathrm{NI}$ \\
\hline \multicolumn{9}{|l|}{ Family Cuniculidae Miller and Gidley, 1918} \\
\hline Cuniculus paca (Linnaeus, 1766) - Spotted Paca, Paca & $\mathbf{\square}$ & $\mathbf{\square}$ & & & & $\mathbf{\square}$ & LC & $\mathrm{NI}$ \\
\hline \multicolumn{9}{|l|}{ Family Dasyproctidae Bonaparte, 1838} \\
\hline $\begin{array}{l}\text { Dasyprocta prymnolopha Wagler, } 1831 \text { - Black-rumped } \\
\text { Agouti, Cutia-da-garupa-preta }\end{array}$ & $\mathbf{\square}$ & घ & - & & & घ & LC & $\mathrm{NI}$ \\
\hline \multicolumn{9}{|l|}{ Family Erethizontidae Bonaparte, 1845} \\
\hline $\begin{array}{l}\text { Coendou baturitensis Feijó and Langguth, } 2013 \text { - } \\
\text { Baturite porcupine, Porco-espinho, Ouriço-cacheiro }\end{array}$ & - & $\mathbf{\square}$ & & & & & NA & NA \\
\hline $\begin{array}{l}\text { Coendou prehensilis (Linnaeus, 1758) - Brazilian } \\
\text { porcupine, porco-espinho, ouriço-cacheiro }\end{array}$ & $\mathbf{\square}$ & - & - & & & & LC & $\mathrm{NI}$ \\
\hline TOTAL: 41 Species & 31 & 38 & 31 & 24 & 23 & 25 & & \\
\hline
\end{tabular}

Legend: F- Food resource, M- Medicinal, MR- Magic/religious, P- Pets, O- Ornamentation and decoration, CRConflicting relationships. Brazil Red List (Brazil's List of Endangered Species); IUCN Red List categories (World Conservation Union; www.iucnredlist.org/): LC - Least Concern, CD - Conservation dependent, CE - Critically Endangered, EN - Endangered, NT - Near threatened, VU - Vulnerable, NA - Not assessed and NI - Not Included.

\section{ORDER CINGULATA}

Family Dasypodidae Gray, 1825

Dasypus novemcinctus Linnaeus, 1758 (Figure 1) - Common names: Nine-banded armadillo, Tatugalinha, Tatu-verdadeiro

Characteristics: Medium-sized armadillo (head-body length: $385 \mathrm{~mm}$ ). Its head is narrow, long and conic. The ears are well developed and close together. As in the other armadillos, a carapace covers the dorsal surface of the head, body and tail. The carapace which covers the body is divided into a scapular shield, a pelvic shield, and eight to ten mobile transversal bands between these two. The small plates which compose the scapular and pelvic shields have a polygonal form. They are smaller than those on the mobile bands that are rectangular. Its manus has four fingers, the second and the third are the most developed and the hindfoot has five toes. The dorsal color is dark brown, while the laterals are yellowish. The abdomen is yellowish and sparsely covered with harsh, white hairs. The skull has a long, narrow, and tubular rostrum. The zygomatic arches, in lateral view, are short and concave, and in dorsal view they are narrow and parallel to each other or slightly converging anteriorly. The palate is long. The dentition is hypsodont, simple, and their dental formula is 7-8/7-8. 


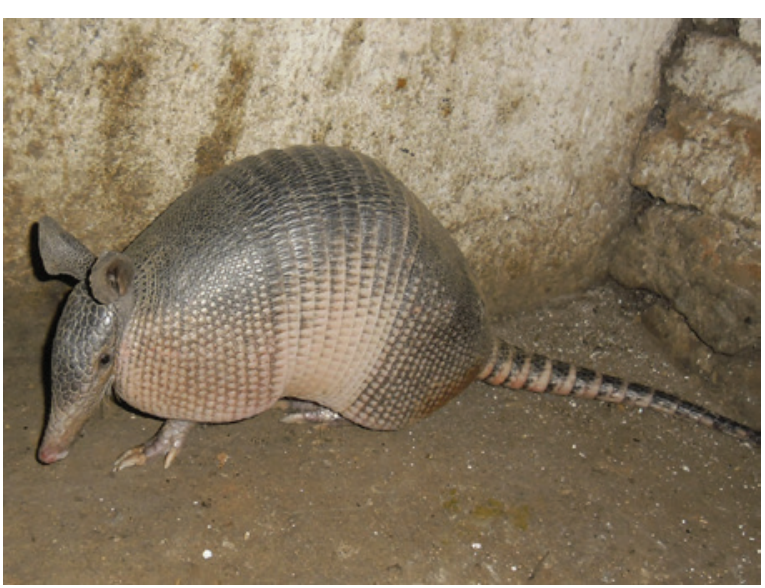

Figure 1. Dasypus novemcinctus Linnaeus, 1758 (Photo: Gleidison Lima).

Distribution: $D$. novemcinctus distributed from the United States to the north of Argentina and Uruguay, occurring in several types of habitats (Wetzel et al. 2008). In the Caatinga, D. novemcinctus is widespread, and present on several phytophysiognomies (Feijó and Langguth 2013).

Ethnozoological notes: Dasypus novemcinctus is one of the main preys of the hunters dwelling in the Caatinga. This species is, commonly, captured with the help of dogs. There are also specific traps for its capture called "tatuzeiras", "jereré" or "jequi" by the locals. This wire trap has a cylindrical shape, with an opening in one of the ends having a triggered door that closes after the animal has entered it. This type of trap is used when the prey hides in its burrow. It is then placed in the mouth of the burrow so that when the animal comes out looking for food or water it is caught inside the trap. Often the hunter simply leaves the cage and comes back the next day to see if the animal has been captured (Alves et al. 2009a).

The $D$. novemcinctus' hunt is motivated, mainly, by its value as a meat source. Consumption of this and other armadillos is registered in several historical reports. Pero de Magalhães Gândavo (Gândavo 1858), in the book "História da província Santa Cruz, a que vulgarmente chamamos Brasil" ("History of the Santa Cruz province, the one we commonly call Brazil", free translation) describes the armadillo's meat as the most delicious in Brazil. The preference of the Brazilian Indians for these animals was also pointed out by other authors (Anchieta 1984; Cardim 1997; Léry 1997; Piso and Marcgrave 1648; Staden 1974; Thevet 1978) in several documents from the sixteenth and seventeenth centuries. Those documents reveal that these animals have been hunted since the early beginnings of the human occupation of the Neotropics.

The meat of the $D$. novemcinctus is greatly appreciated in the semi-arid region, even being compared to chicken's meat. Such a comparison had already been noted by Gândavo (1858). They are considered a "clean animal" since their diet is based on roots, potatoes, and small insects. These characteristics confer a high market value to the nine-banded armadillo, one of the game species more valorised in semiarid region. In 1648, George Marcgrave, a naturalist that portrayed the Natural History of Brazil and concentrated most of his studies on the northeastern region of the country, also points out the people's preference for eating the $D$. novemcinctus compared to other game species.

Although the meat is the main product derived from the species, there are several other secondary products which are used for different purposes. The carapace of the armadillo or even the whole stuffed animal are used as a decorative object (Figure 2). The tail, skin and fat are used in popular medicine for treatment of the following ailments: ear aches, deafness, burns, inflammations, rheumatism, erysipelas, skin problems, respiratory illnesses, sore throat, snake bites, asthma, tumours, swelling, infections and bronchitis. For example, the tail is introduced into the ear to combat deafness in various localities in Northeastern Brazil (Alves 2009; Ferreira et al. 2009a). Fat is rubbed onto burns and inflammations, and the meat is eaten without salt to treat pains in the bones (Ferreira et al. 2009a, b).

It is important to highlight that the species is a natural reservoir of etiological agents of several zoonotic diseases that affect humans such as leprosy, trichinosis, coccidioidomycosis or Valley Fever, Chaga's disease and typhus (Silva et al. 2005). Costa et al. (2001) detailed a fatal case of an armadillo hunter infected with pulmonary coccidioidomycosis in Ceará State, northeastern Brazil. The disease is caused by the inhalation 
of arthrospores from the fungus Coccidioides immitis. The hunter had participated in an armadillo hunt five days prior to showing symptoms and a second participant had also shown similar symptoms, though these later spontaneously disappeared. Eulálio et al. (2001) found that 3 of 26 armadillos of this species captured in Piauí State, Brazil were infected with Coccidioides immitis. Recently, in the state of Piauí, more than 100 occurrences of pulmonary mycosis were recorded in 40 municipalities over the state. This disease is transmitted by a fungus present in the armadillo's organism. Whether for food or medical purpose the consumption of armadillos can be a vector of various human diseases (Alves et al. 2015)

The armadillos can also be a reservoir of zoonotic diseases that affect domestic animals.
The blue tongue is a viral disease that affects ruminants, transmitted by haematophagy by vectors of the genus Culicoides (Alves et al. 2009a). The armadillos, after being captured, are kept near human residences, creating, a possible transmission connection (Osburn 1994).

Occasionally, the species is used as pet, but usually they are only kept to fatten for latter consumption. Nowak (1991) says that although easily tamed they do not adapt well to captivity. Actually, in the semiarid areas of northeastern Brazil this practice is more related to the yellow armadillo, Euphractus sexcinctus (Alves et al. 2009a, 2012a). The species is considered a minor agricultural pest on account of its burrowing activities which affect fruit and agricultural plantations.
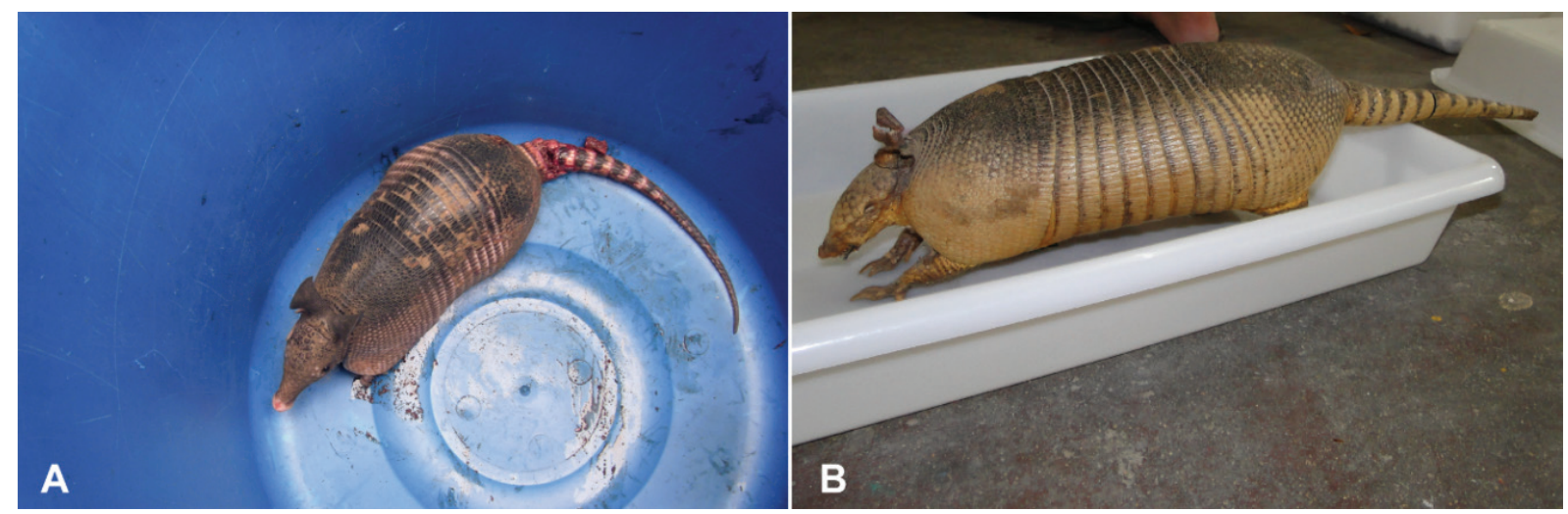

Figure 2. Dasypus novemcinctus kept in a plastic container after hunt $(A)$ and taxidermized for use as a decorative object (B) (Photos: Raynner Rilke Duarte Barbosa (A) and Wedson Medeiros Silva Souto (B)).

Dasypus septemcinctus Linnaeus, 1758 (Figure 3) - Common names: Brazilian Lesser Long-nosed Armadillo, Tatu-mirim ou tatu-china

Characteristics: Small-sized species with narrowed, long and conic head. The mobile bands vary from six to seven. The ears are well developed and close together. The plates that compose the pelvic and scapular shield have a polygonal shape and are smaller than those found on the mobile bands which are rectangular. The scutes on the proximal half of the tail are bound together to form 9 to 13 distinct rings. Each ring possesses two plate rows, the more distal one has a straight edge. The manus has four digits, the second and the third one being the most developed, and the hindfoot has five digits. The carapace colour is uniformly dark brown. The skull is similar to that of $D$. novemcinctus but slightly smaller and with a straight dorsal profile. 


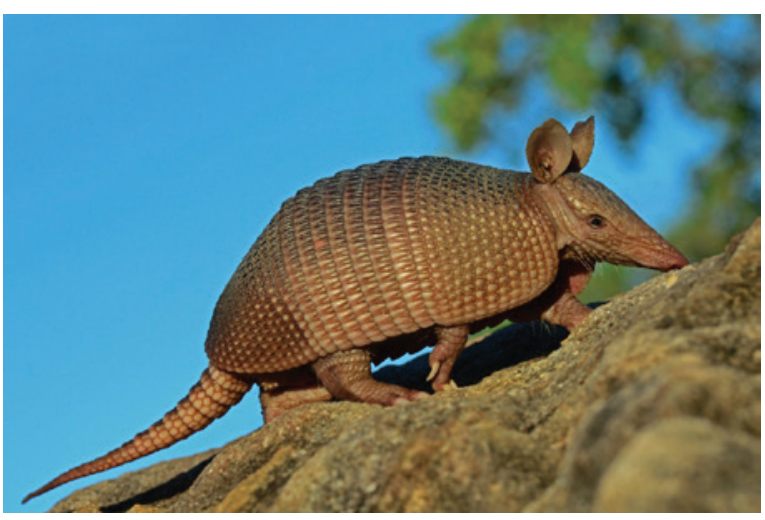

Figure 3. Dasypus septemcinctus Linnaeus, 1758 (Photo: André Pessoa).

Distribution: D. septemcinctus is distributed through the lower part of the Amazon river through eastern Brazil southwards to Rio Grande do Sul state, and westwards to Mato Grosso state, eastern Bolivia, Paraguay, and the northern of Argentina (Wetzel et al. 2008). Currently, this species is considered rare in the Caatinga (Feijó and Langguth 2013).

Ethnozoological notes: In a study on the hunting practices in the state of Pernambuco, Valle (2007) registered that $D$. septemcinctus are captured with the help of hunting-dogs. Possibly, this species is also captured with the same hunting traps used for other armadillo species of the region, and they serve to the same purpose in human consumption (food and medicinal purposes).

Euphractus sexcinctus (Linnaeus, 1758) (Figure 4) - Common names: Yellow armadillo, Tatu-peba, Peba

Characteristics: Medium-sized armadillo (headbody length: $452 \mathrm{~mm}$ ). The head is large triangular shape, and flattened dorsally. The ears are small and placed laterally on the head. The carapace is yellowish. The transversal mobile bands vary from six to seven in the middle part of the body. In the mid region of the pelvic shield, there are two or three openings for odoriferous glands. The manus has five digits with large claws; the third is the longest. The hindfoot has five digits; the first and the fifth are the shortest ones. The skull is robust and the rostrum is wide and triangular. The anterior end of the nasals bones extend beyond the premaxillar. The teeth are homodont. The dental formula is $9 / 10$.

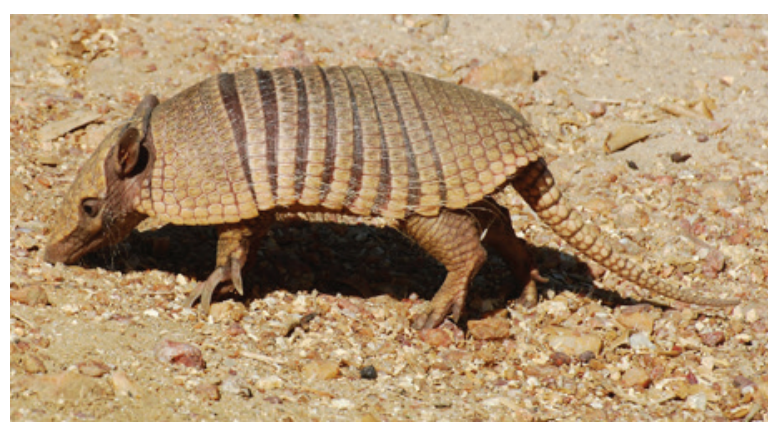

Figure 4. Euphractus sexcinctus (Linnaeus, 1758) (Photo: John Philip Medcraft).

Distribution: Euphractus sexcinctus is present in a wide area of South America, from southern Suriname and adjacent Brazil to Bolivia, Paraguay, Uruguay, and northern Argentina (Redford and Wetzel 1985). This species is widely distributed in the Caatinga, Cerrado, and in the Atlantic Forest (Feijó and Langguth 2013; Silva-Júnior and Nunes 2001).

Ethnozoological notes: Recent ethnozoological researchers suggest that $E$. sexcinctus is probably supposedly as a consequence of the omnivorous diet of the animal, which includes carcasses of dead animals (Alves et al. 2012a, 2009a). Redford (1994) mentioned that the meat is said to have a strong flavour, and is a food taboo in some areas diminishing the hunting pressure. In the Caatinga, the pressure on E. sexcinctus is intense. Many hunters developed strategies to maintain them in captivity aiming to "to clean" its digestive trait through a controlled diet, for human consumption (Alves et al. 2012a; Fernandes-Ferreira et al. 2012).

In addition to the use of meat as a food source, many products derived from the $E$. sexcinctus are used secondarily in popular medicine. Fragments of tail, skin and fat, are prescribed to treat wounds, earache, asthma, sore throat, pneumonia, sinusitis, deafness, coarse throat or to deflect envy (Alves 2009). In addition, as pointed out by Confessor et al. (2009) and Souto et al. (2011), the fat of $E$. sexcinctus is also used in ethnoveterinary practice for the treatment of furuncle in livestock.

Among the Pankararé Indians, in the state of Bahia, the armadillo tail is used by hunters to make whistles that imitate the fowl's singing or the grunt of other animals in order to attract the prey 
(Sampaio et al. 2009). These authors emphasize that the use of the tail of the peba armadillo for the manufacturing of these whistles by the Pankarare, constitutes in itself a trait of this ethnic group. Pankararés also use this armadillo as food and in their handicrafts.

The carapace of the yellow armadillo can be used as a decorative object, and living specimens are raised as pets. The hunting of the yellow armadillo can be assisted by hunting-dogs (that sometimes follow their tracks), and traps called "tatuzeiras" (armadillo traps), following the same strategies aforementioned for the nine-banded armadillo (Figure 5) (Alves et al. 2009a). In some cases, a combination of techniques can also be used, for instance, the hunter may search tracks with dogs to find an armadillo burrow, and then set up a trap.

Euphractus sexcinctus and Dasypus novemcinctus are the most abundant armadillo species in the semiarid region (Feijó and Langguth 2013). Despite their similar abundance, hunters prefer D. novemcinctus, what might be inducing population depletion in some communities (Alves et al. 2012a, 2009a). In some regions, such as the Serra de Baturité, Ceará state, hunters commercialise captured $D$. novemcinctus for higher prices (around US\$10.00) compared to Euphractus sexcinctus that sell for around US\$ 7,00 (Fernandes-Ferreira 2011).

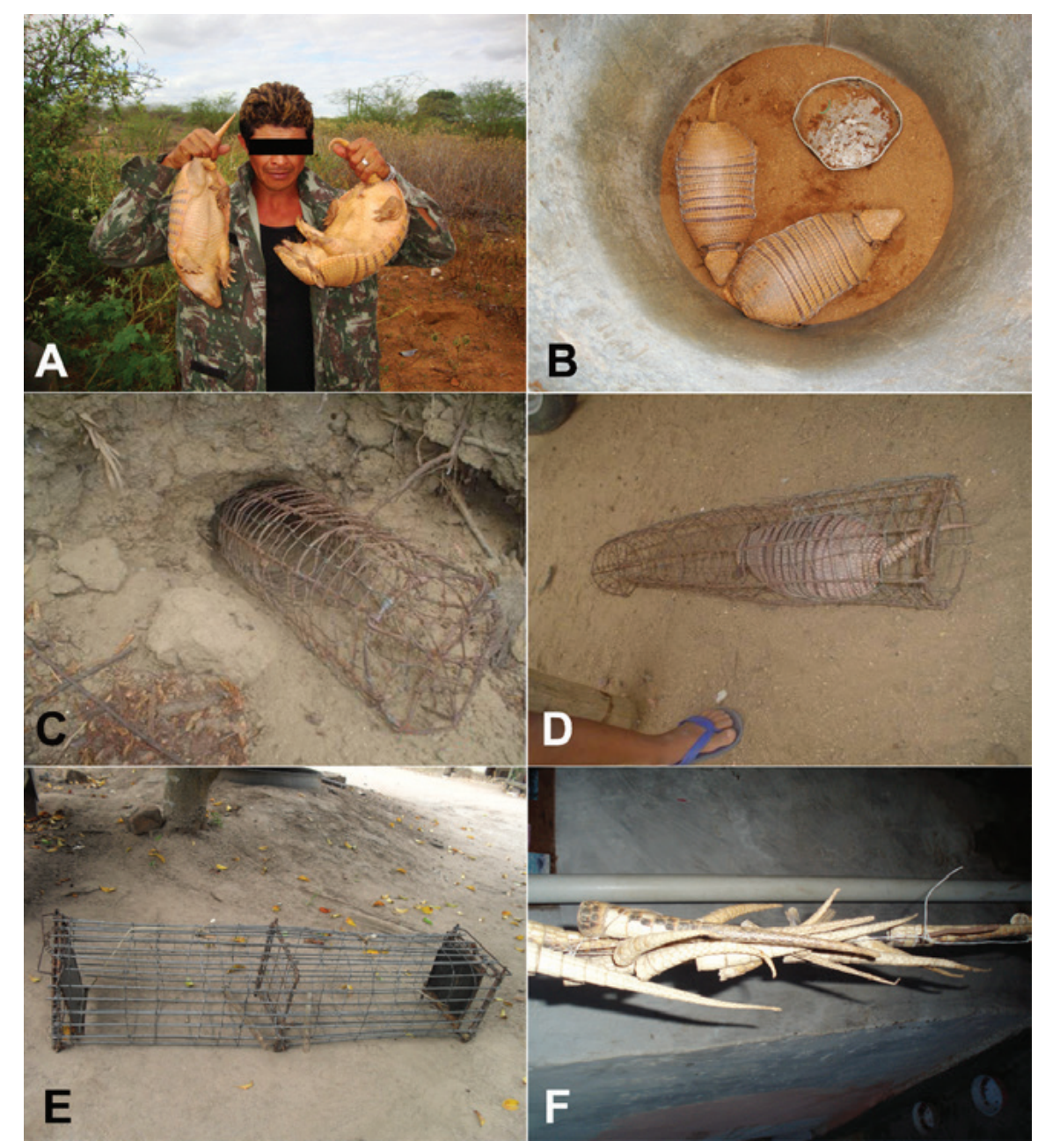

Figure 5. Examples of interactions between people and armadillos in the semiarid region of Brazil. A hunter displaying specimens of $E$. sexcinctus after a catch (A); six-banded armadillos in captivity to fatten (B); Armadillo traps (placed on the opening of the animal's burrow (C), with armadillo caught (D) and square shape (E); armadillo tails, used for medicinal and magic religious purposes in Brazilian semiarid region. Photos: Raynner Rilke Duarte Barboza (A), Wedson Medeiros Silva Souto (B and D), Rômulo Romeu Nóbrega Alves (C, E and F). 
Tolypeutes tricinctus (Linnaeus, 1758) (Figure 6) - Common names: Three-banded armadillo, Tatu-bola

Characteristics: Small-sized armadillo (headbody length: $240 \mathrm{~mm}$ ). Tolypeutes is the only armadillo that has the ability to roll up completely into a ball, hence its vernacular name tatu-bola (ball-armadillo). Tolypeutes tricinctus has a hard and convex carapace, it generally has three transversal mobile bands. The head has a triangular shape and is flattened dorsally. The cephalic shield is composed of approximately 30 large plates which are composed of a posterior central plate, followed by an anterior pair, then by another pair and finally by an anterior central plate. The ears are rounded and can fold in half when the animal is curled. The tail is short and completely covered by small round plates. The carapace colour is dark yellow. The abdomen has long yellow and white hairs. The manus has five digits, the third one is the larger. Digits of pes have hoof-like claws, the second, third, and fourth digits are equal length. The skull possesses a wide rectangular rostrum. The extremity of the nasals extend anteriorly beyond the premaxilla. The teeth are cylindrical, homodont, and have, generally, eight pairs on the jaw and from seven to eight pairs on the maxilla.

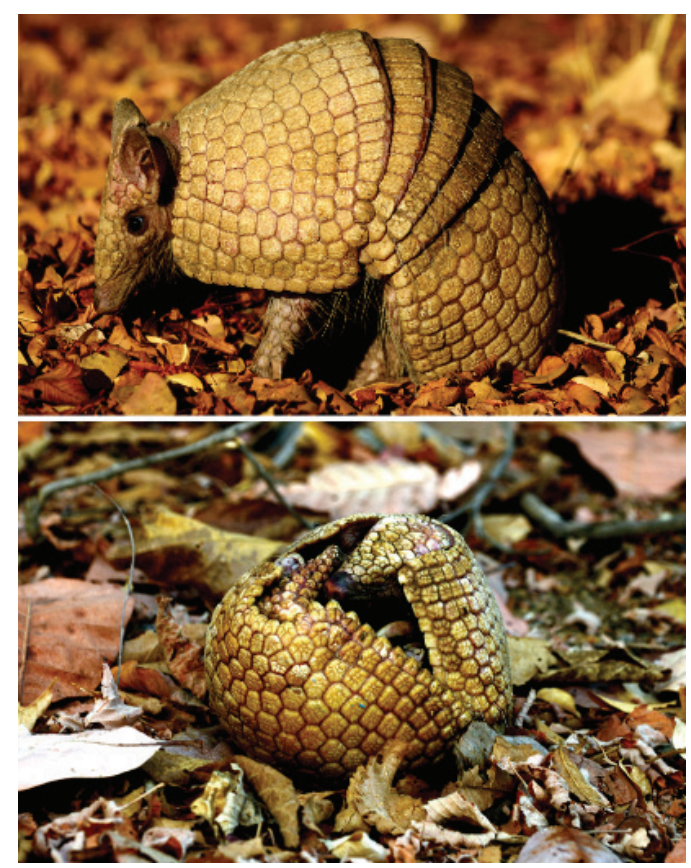

Figure 6. Tolypeutes tricinctus (Linnaeus, 1758). Below, the animal in its characteristic ball-shape position (Photos: André Pessoa).
Distribution: T. tricinctus is endemic to Brazil where it can be found throughout the highlands surrounding the middle course of the São Francisco River and on the oriental slope of the Parnaiba River valley, as well as on the occidental slope of the Borborema plateau (Feijó et al. 2015). Its occurrence has been registered in the Caatinga in the states of Bahia, Ceará, Pernambuco, and adjacent regions of the Cerrado of Maranhão, Tocantins, and Bahia states (Feijó and Langguth 2013).

Ethnozoological notes: As with the aforementioned species, T. tricinctus is used as food, for medicinal purposes and its carapaces are used to manufacture ornamental objects. Recent ethnozoological studies, have not registered either hunting or use of this species probably due to the population decline and local extinctions in many places of the semiarid regions (Melo et al. 2014b). In fact, the three-banded armadillo, which was thought extinct in the Caatinga, was re-discovered in the remaining seasonall dry forests of the western portion of Bahia state (Santos et al. 1994; Silva and Oren 1993). Nowadays, in the Caatinga, the remaining populations are virtually isolated in protected areas and are subject to subsistence hunting (Superina and Abba 2010).

Cabassous tatouay (Desmarest, 1804) (Figure 7) - Common names: Greater Naked-tailed Armadillo, Tatu-de-rabo-mole, Tatu-rabo-de-couro

Characteristics: Medium-sized species (headbody length: $450 \mathrm{~mm}$ ). The carapace colour is brownish yellow. The muzzle is rounded and robust. The cephalic shield has wide and symmetric dermal plates which vary in number from 44 to 52 . On the dorsal portion of the neck there are three transversal bands of small dermal plates. The movable bands vary in number from 10 to 13 on the midline. The ears are large, rounded, cone shaped, and placed laterally on the head. The tail is conical and lacks bony plates, only few small scales are present on the ventro-distal portion of the tail. This characteristic is responsible for the vernacular names "soft tailed armadillo" or "leather tailed armadillo". The manus has five digits with very large claws on the third and the fourth, the former being the most developed. The hindfoot has five digits with claws not as developed as the forelimb. The 
skull is wide, the rostrum is triangular. The nasals extend anteriorly to the premaxilla. It has nine pairs of maxillary teeth and eight mandible pairs.

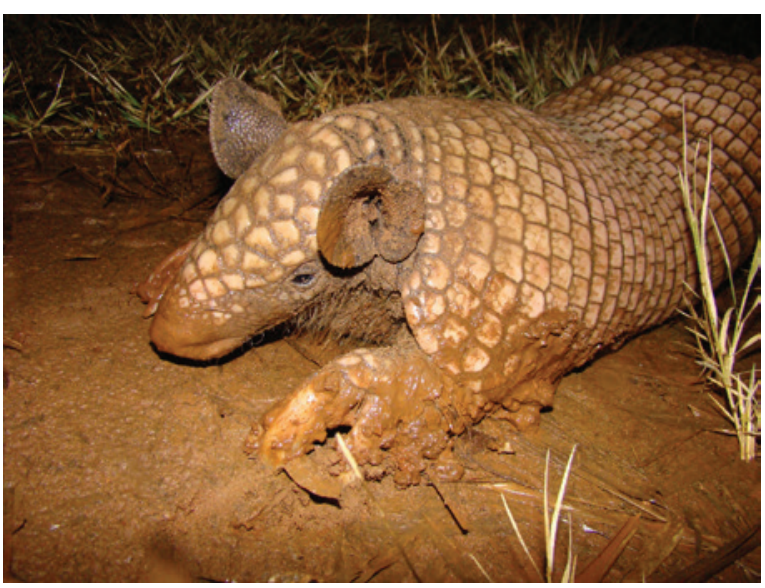

Figure 7. Cabassous tatouay (Desmarest, 1804)(Photo: Flávio Kulaif Ubaid).

Distribution: It is distributed throughout the north of Argentina, the south of Paraguay, and in the central and eastern regions of Brazil in the states of Pará, Mato Grosso, Minas Gerais, Paraíba, Pernambuco, and Ceará (Feijó and Langguth 2013; Wetzel et al. 2008). In the Caatinga, C. tatouay is associated to humid forests, such as Brejos de Altitude (Feijó and Langguth 2013).

Ethnozoological notes: Even though they can be used for the same ends as the previous armadillo species, currently this species is not frequently hunted. This is certainly related to its geographical distribution in the Caatinga which is more restricted than the other armadillo species of the region.

Priodontes maximus (Kerr, 1792) (Figure 8) Common names: Giant armadillo, Tatu-canastra

Characteristics: The P. maximus is the largest living armadillo species, with its total length reaching up to 1.5 meters, weight up to 50 kilograms (Husson 1978). The head is conical and the ears are placed laterally on the head. The carapace colour is dark brown, with a large yellow stripe on the sides. The numbers of mobile bands vary from 11 to 13 . The tail is distinctly smaller than the body and the plates of carapace are pentagonal and not set in rings. The third finger of the manus has a long and strong claw, almost four times longer than that of the second finger. The skull is easily distinguished from other armadillos by its size and by its larger number of teeth, which vary from 65 to 98 (Husson 1978).

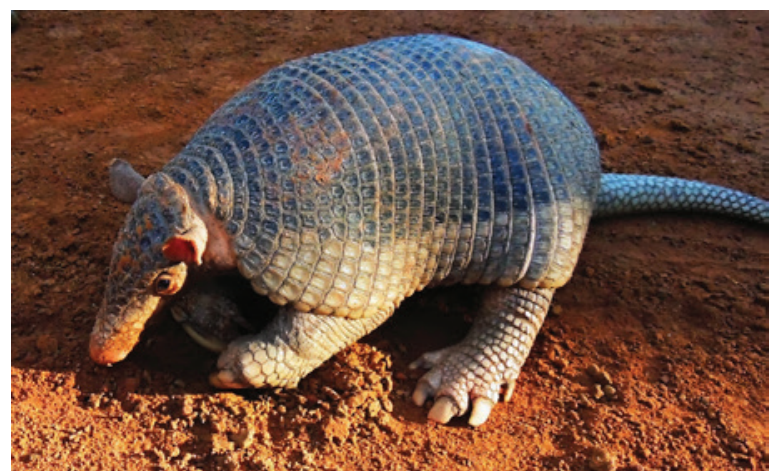

Figure 8. Priodontes maximus (Kerr, 1792) (Photo: Raphaella Coutinho)

Distribution: P. maximus is recorded from the eastern slope of the Andes, including Colombia, Venezuela, Ecuador, Peru, Bolivia, Guianas, Argentina, Brazil and Paraguay (Wetzel et al. 2008). In the Caatinga records are scarce and are present only in the western part of the state of Piauí, near the Cerrado biome.

Ethnozoological notes: $P$. maximus is threatened by hunting for meat (generally for subsistence) and deforestation of its habitat. The illegal capture of giant armadillos for clandestine sale to wealthy animal collectors may also be a threat, but is difficult to quantify (Superina and Abba 2010). There are meat consumption reports for this species, which is cooked in its own carapace. The latter serves as domestic ornaments and objects. Peixoto (2006) mentions that its shell, was used as cradle for infants in the past.

\section{ORDER DIDELPHIMORPHIA}

Family Didelphidae Gray, 1821

Didelphis marsupialis Linnaeus, 1758 (Figure 09) - Common names: White-eared opossum, Timbude-orelha-branca, Cassaco-de-orelha-branca

Characteristics: Large-sized didelphid (headbody length: $265 \mathrm{~mm}$ ). The general color of the body is blackish with long white hairs sparse along the 
body giving the fur a heavily grizzled appearance. The ventral surface of body has a dirty white or cream color. On the dorsum of the head there is a longitudinal dark stripe, which extends from the base of the muzzle to the nape, where it becomes wider. A black ring is present around each eye, which extends forward and backward. The tail is longer than head-body length, with a darker proximal portion and a whitish distal portion of the tail. The ear is well developed and mostly white, with some dark stains at its base (Gurgel-Filho et al. 2015).

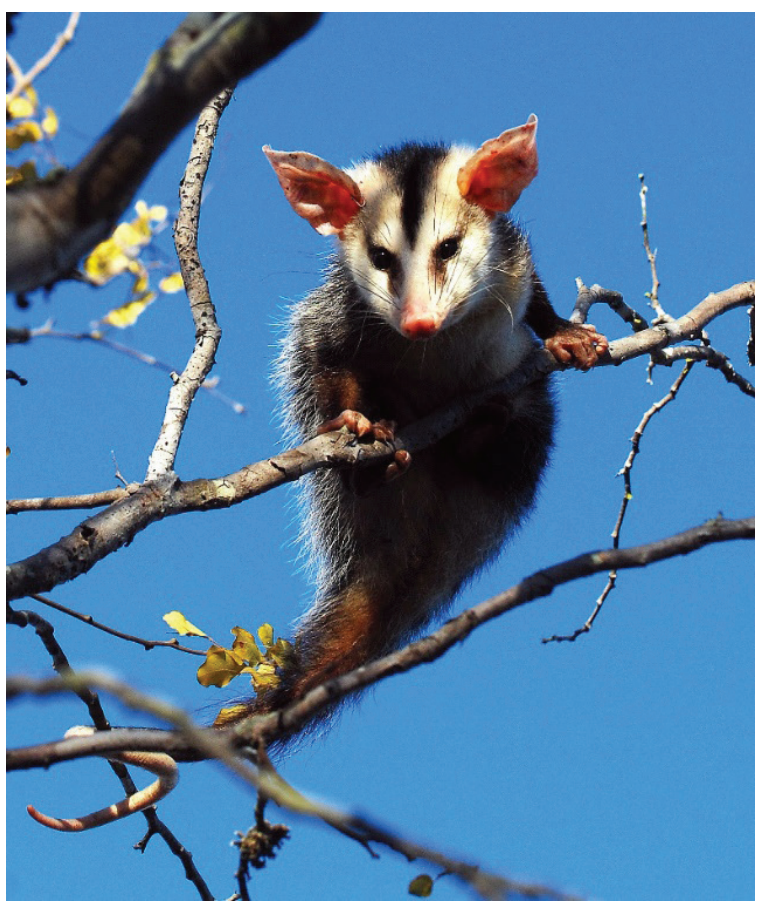

Figure 9. Didelphis marsupialis Linnaeus, 1758 (Photo: André Pessoa).

Distribution: Didelphis marsupialis occurs from northeastern, central and south Brazil extending to Uruguay, Argentina, Paraguay and east of Bolivia (Cerqueira and Tribe 2008).

Ethnozoological notes: Hunting of $D$. marsupialis (previously Didelphis albiventris, see Gurgel-Filho et al. 2015) had already been recorded by Alves et al. (2009a) in the semiarid region from Paraíba State. Despite the strong odor released by these animals and the rejection of its meat in other regions of Brazil, the consumption of them is relatively high in Caatinga biome with some records of commerce in open markets (Barboza 2013; Fernandes-Ferreira 2014; Souto
2014). In order to neutralize this smell, people cite that it is necessary to remove the body hair. Rossi et al. (2006) point out that the odoriferous substance comes from the perianal glands of Didelphis, which are located under the skin. After the release of the substance, the hair may become impregnated. The process of hair removal is usually performed through burning, neutralizing the odor impregnated in the follicles. Furthermore, the removal of the skin eliminates the contact of the consumer with the perianal glands. The species is hunted with firearms, dogs, letal and non-letal traps.

Didelphis karkinophaga Zimmermann, 1780 (Figure 10) - Common names: Black-eared opossum, Timbu-de-orelha-preta, Cassaco-deorelha-preta

Characteristics: Large-sized didelphid (headbody length: $245 \mathrm{~mm}$ ). The general color of the body is black with long white hairs sparse mostly in the posterior region of the dorsum. The ventral surface is cream. The dorsum of the head is black and exhibits a longitudinal black stripe, which extends to the muzzle. A black ring is present around each eye. The ears are large and totally black. The forelimbs and hindlimbs are black and the tail is slightly smaller than head-body length and bicolor, with a darker proximal portion and a whitish distal portion (Gurgel-Filho et al. 2015).

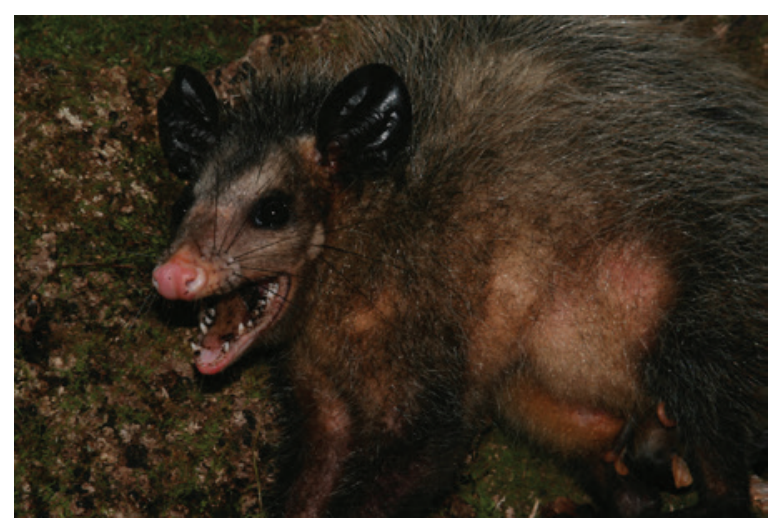

Figure 10. Didelphis karkinophaga Zimmermann, 1780 (Photo:Thiago Borges Fernandes Semedo).

Distribution: This species is widely distributed, extending from Mexico, Central America, French Guiana, Suriname, Guyana, Venezuela, Colombia, 
Ecuador, Peru, Bolivia, north and west of Brazil to the east of Brazil and Paraguay (Cerqueira and Tribe 2008). Fernandes-Ferreira et al. (2015) recorded this species for the Brejos de Altitude of Ceará state.

Ethnozoological notes: The fact of the occurrence of this species in Caatinga is limited to Brejos de Altitudes does not provide consistent data about its use. However, interviews conducted in Baturité and Ibiapabas ranges (Ceará State) show that there are no differences in the hunting methods and consumption patterns between $D$. karkinophaga and D. marsupialis (FernandesFerreira 2014).

\section{ORDER PILOSA}

Family Myrmecophagidae Gray, 1825

Tamandua tetradactyla (Linnaeus, 1758) (Figure 11) - Common names: Southern Tamandua, Tamanduá-de-colete, Tamanduá-mirim, Collared anteater

Characteristics: Medium-sized anteater species (head-body length: $502 \mathrm{~mm}$ ). The fur is short on the head, neck, and limbs, and longer on the body and on the tail. There is a brown area around the eyes which extends to its muzzle. The anterior part of the body is golden yellow, including the head, neck, the inferior portion of the limbs extending to the anterior portion of dorsum and forming a triangle with a posteriorly oriented vertex. On the shoulders two black colored bands connect the black areas of the dorsum with the abdominal areas, forming a black vest. The vest can be totally black, partially black or almost imperceptible, having the same colour as the limbs. The manus has four digits, the third is the most developed with a robust claw, and the first one is small. All digits of the hindfoot are of equal size. The tail is golden yellow, prehensile, and nude on its distal portion. The skull is long with a straight dorsal surface. They lack teeth. The palate is long, terminating at edge of the posterior tympanic bulla.

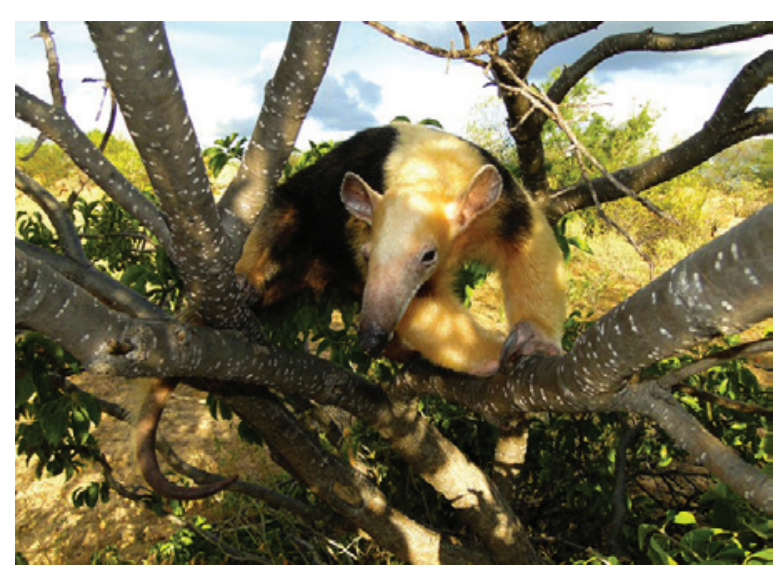

Figure 11. Tamandua tetradactyla (Linnaeus, 1758) (Photo: Wedson Medeiros Silva Souto).

Distribution: This species is restricted to South America, distributed all over Brazil and in the adjacent parts of the neighbouring countries (Gardner 2008). It is widely distributed in the Caatinga (Feijó and Langguth 2013).

Ethnozoological notes: Nowadays, the species is on the list of the most hunted mammals of the Caatinga (Alves et al. 2009a). It is hunted as a food resource and to use in popular medicine. In this last case, products derived from the species are used for the treatment of edemas and thrombosis (Alves 2009). The medicinal or alimentary usage of the anteater does not occur exclusively in the Caatinga, but also in other biomes of Brazil (Lisboa 2002) and South America (Bodmer and Lozano 2001; Hill and Padwe 2000; Vargas 2002).

The behavioural characteristic of the species, which moves slowly, is one of the aspects which facilitates its capture (Cartes 2007; Hanazaki et al. 2009; Neris et al. 2002), although it can represent a fatal danger to the hunting dogs, when anteaters uses their claws as defence (Alves et al. 2012a, 2009a; Fernades-Ferreira 2011). The risk these animals represent for dogs is one of the reasons they are killed.

Meritt (2008) notes that the foul smell of this species may be an impediment to its consumption in the Paraguayan Chaco, but that this factor may become less important if other prey species become uncommon. This situation is frequent in the Brazilian semiarid region, where the hunt is often not directed to the anteater (Alves et 
al. 2012a, 2009a). Although it is not frequent, the species can be used as a pet (Figure 12), being evencommercialised for this purpose (Fernandes-Ferreira 2011).

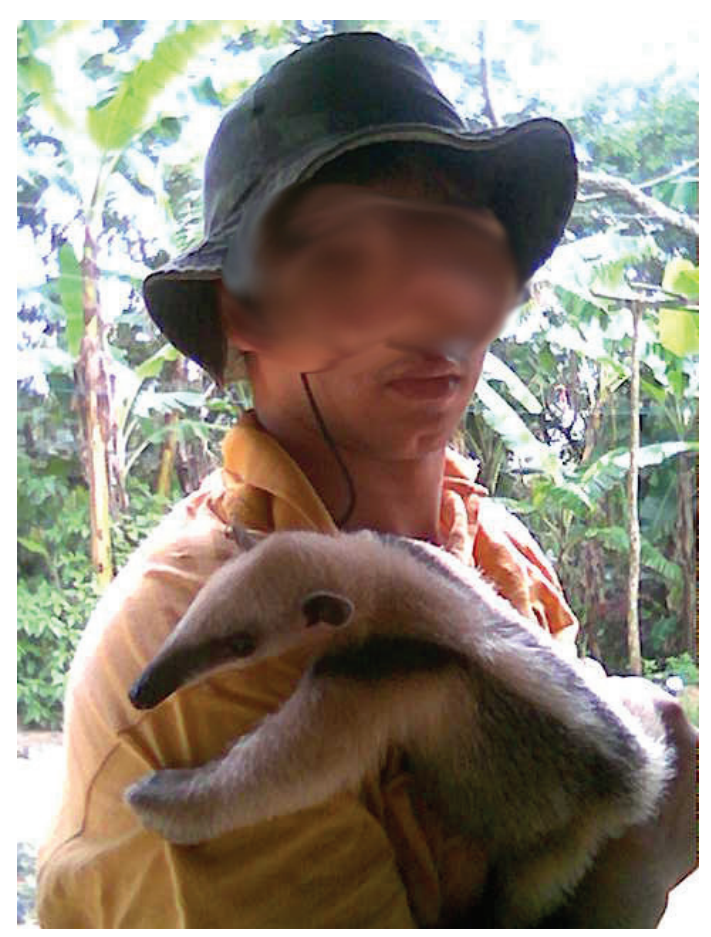

Figure 12. Tamandua tetradactyla (Linnaeus, 1758) kept as a pet in the Brazilian semiarid area (Photo: Sanjay Veiga).

Myrmecophaga tridactyla Linnaeus, 1758 (Figure 13) - Common names: Giant Anteater, Tamanduá-bandeira

Characteristics: The species is recognizable by its large size averaging around 2 meters from head to tail (Eisenberg and Redford 1999). The general colour of the body pelage is grey or dark brown. The fur is long, thick, and rough. The medium region of the dorsum has a fur crest that increases gradually toward the tail. The head is grey, the nose is black, and the ears are small and rounded. The muzzle is extremely long. The abdomen and the rear paws are dark brown, while the front limbs are white or yellow, with a black patch around the wrist. There is an extended black stripe from the waist region to the neck towards the shoulders, narrowing gradually. The most striking feature is the very long tail, and its dense and long fur. The skull has a long rostrum; the nasal bone is as long as the frontal. There is no zygomatic arch. The palate is long, extending posteriorly to near the condyle. The mandible is long and narrow. They lack teeth.

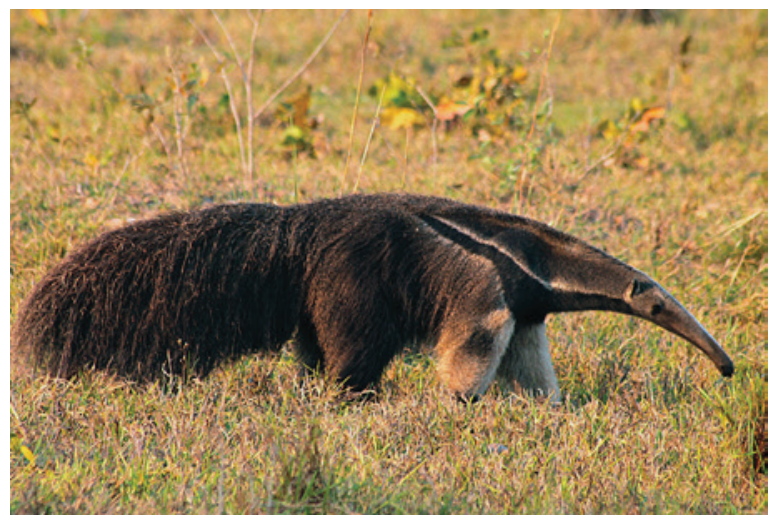

Figure 13. Myrmecophaga tridactyla Linnaeus, 1758 (Photo: Karina Molina).

Distribution: Myrmecophaga tridactyla is a widely distributed species in Central and South America, the northern limit is Guatemala, and Belize, Uruguay, Argentina, Bolivia, and Paraguay are in the southern limit (Gardner 2008). The registered occurrences in the Caatinga are scarce and nowadays are limited to regions close to the Cerrado biome (Feijó and Langguth 2013)

Ethnozoological notes: During the colonization of Spanish America, the giant anteater was one of the most captured animals to be shown in Europe (Cowie 2011). The animal's skin (Figure 14) has an ornamental value and its meat is used as food. Products derived from the animal are also used in popular medicine. Alves et al. (2012c) registered the species' usage in religious witchcraft rituals in the North and Northeastern regions of Brazil. Many communities still believe in legends and myths about the giant anteater, usually, based on its peculiar morphology and mainly its very furred tail, its muzzle and long claws (Bertassoni 2012). Lots of these myths describe the species as being a ferocious animal, capable of striking a human being with its muzzle and even killing a jaguar with its clutches. Some cultures consider it as symbol of "bad luck" (Bertassoni 2012; Shaw and Carter 1980). These authors emphasize that these reports can negatively impact the conservation of giant anteaters in some localities where the animals are considered dangerous to humans. Their attacks on hounds also motivates their slaughter. 


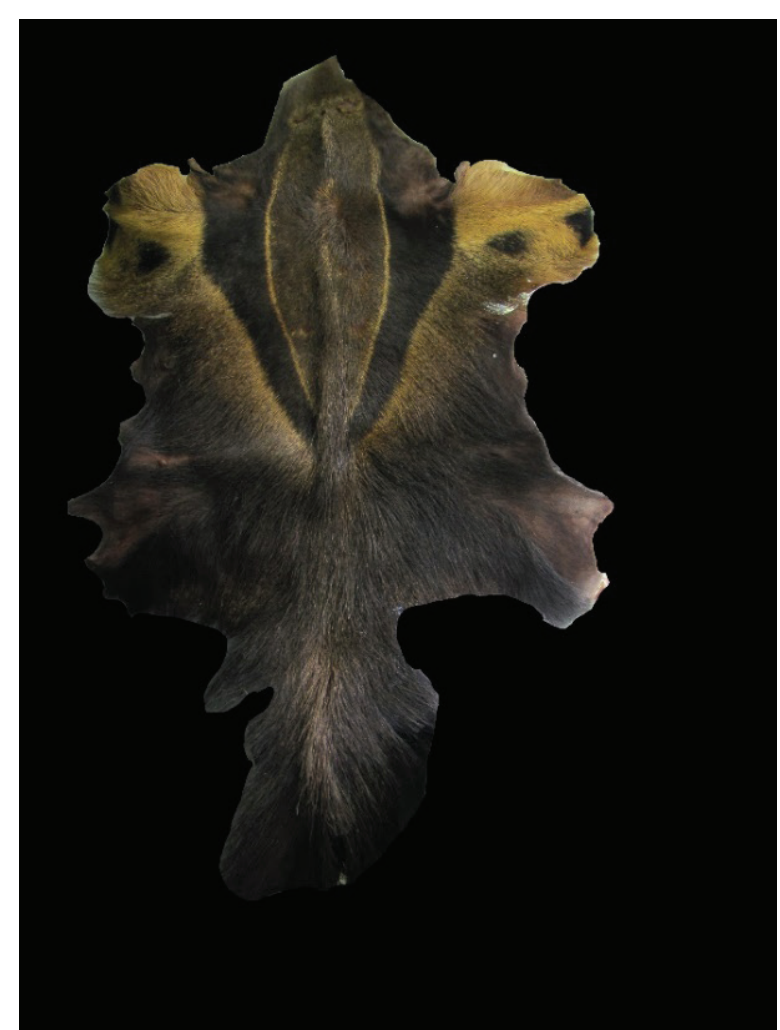

Figure 14. Skin of Myrmecophaga tridactyla Linnaeus, 1758, product with an ornamental value (Photo: Anderson Feijó).

Family Bradypodidae Gray, 1821

Bradypus variegatus Schinz, 1825 (Figure 15) Common names: Brown-throated Sloth, Preguiçade-garganta-marrom

Characteristics: Medium-sized species (headbody length: $504 \mathrm{~mm}$ ) which shows sexual dimorphism in pelage. The male has at mid dorsum a differentiated region of short yellow fur on the edge and black in the middle, which is called the operculum. The females lack this feature. On the face, the fur is short and whitish from the brow to the edge of the muzzle. There is a black mask around the eyes extending to the back of the head as a lateral stripe on the face. The fur of the body and limbs is long, dense and rough. The dorsal colour is grey brown, with white and grey spots throughout the body concentrated mainly on the shoulders region. The abdomen has a uniform grey brown colour similar to the dorsal, but without white spots. The manus and hindfoot have three digits with strong curved claws. The ear pinnae are small and hidden by the fur. The tail is short and of similar colour as the body fur. The skull has a short rostrum and rectangular nasal bone. The frontal bones are long, wide, convex and inflated at the level of the post-orbital process. The pre-maxillary is reduced and bears no incisive teeth. The zygomatic arch is incomplete. The jugal bones have two welldeveloped processes: one is the ascendant, almost perpendicular to the arch and two times bigger than the inferior, which is descendent. The zygomatic process of the squamosal is robust with a rounded edge and with a slight ventral orientation. The teeth are cylindrical and with no enamel. The mandible is robust and has a narrow vertical ramus.

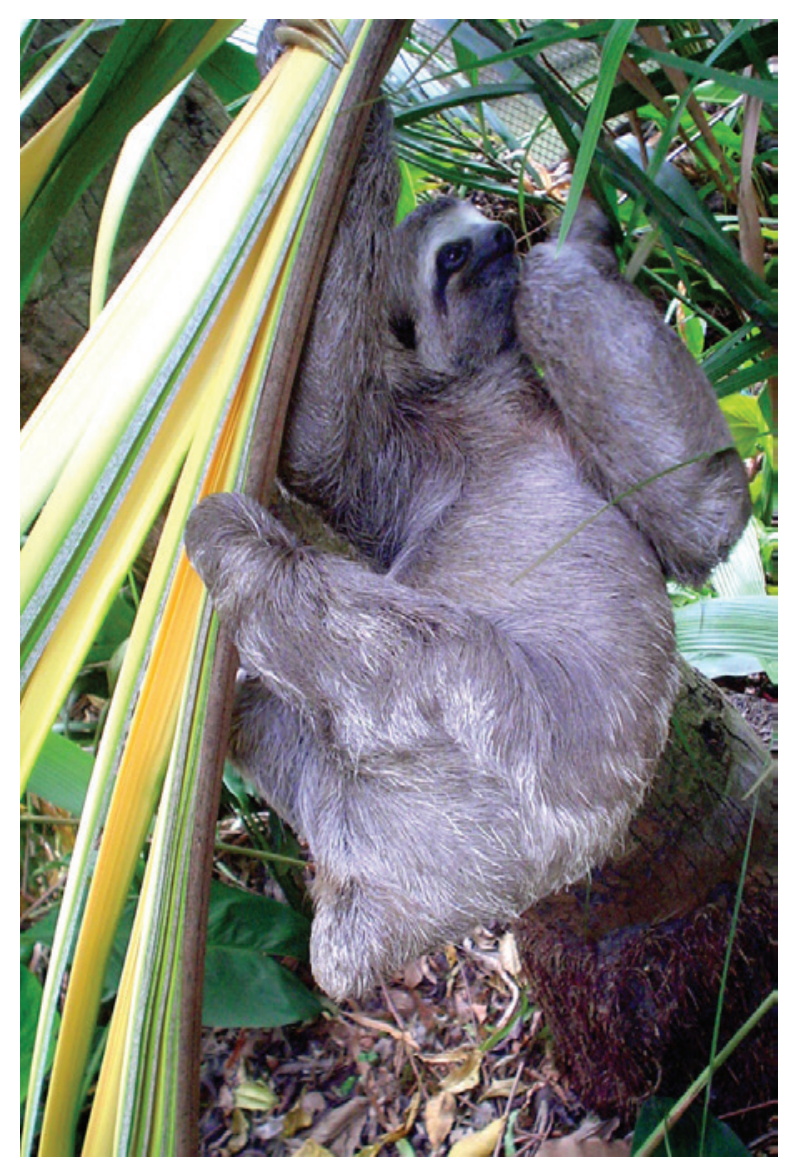

Figure 15. Bradypus variegatus Schinz, 1825 (Photo: Rômulo Romeu Nóbrega Alves).

Distribution: $B$. variegatus is widely distributed in South and Central America. Its occurrence is documented from Honduras through Colombia, Ecuador, part of Venezuela, eastern Peru, northern Bolivia, Paraguay and Argentina (Gardner 2008). If still present in the Caatinga, it probably is restricted 
to the brejos de altitude (Feijó and Langguth 2013). Barboza (2013) registered the species being raised as a pet in a Caatinga region near the Cerrado.

Ethnozoological notes: The species can provide diverse products used by humans, including the meat, used as a protein source, and claws and skin, used for medicinal purposes (Alves et al. 2007, 2013b). The commercialization of medicine products of this species was seen in the Caruaru fair, in the state of Pernambuco (Almeida and Albuquerque 2002). These products may come from other regions since there are commercial trade routes for medicinal products of animal origin connecting other cities in Brazil (Alves and Rosa 2007b, 2010; Ferreira et al. 2012, 2013). The species can also be kept as a pet (Figure 16) (Barboza 2013).

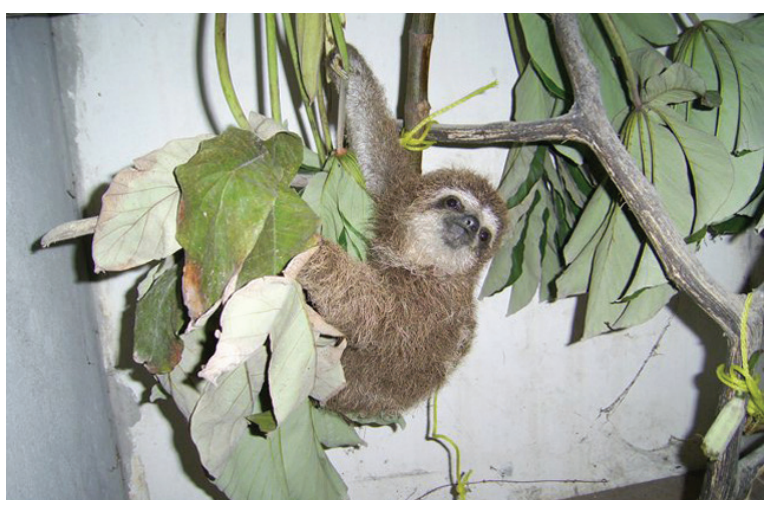

Figure 16. Bradypus variegatus kept as pet (Photo: Raynner Rilke Duarte Barboza).

\section{ORDER PRIMATES}

Family Cebidae Bonaparte, 1831

Cebus (Sapajus) libidinosus (Spix, 1823) (Figure 17) - Common names: Bearded capuchin, Macaco-prego.

Characteristics: A medium-sized primate species (head-body length: $384 \mathrm{~mm}$ ). The fur on the top of the head is long, forming a hood, which is divided into two blackish brown tufts. The nuchal region is rusty red. The pre-auricular strip is dark brown and separated from the hood. The fur of the chin forms a short beard. The colour of the throat and the ventral region is orange-yellow, the thorax is darker than the abdomen. The dorsal region of the body is yellow brown, with some red fur as well. It has a diffuse longitudinal dorsal stripe, interrupted in the anterior third of the dorsum. The arms are yellowish and the forearms brownish with diffuse delimitations. The thighs are yellowish with some red hairs mainly on the medial sides. The lateral of the arms and the dorsal region of feet are brown or dark-brown, sometimes greyish. The tail is dark brown dorsally, with a blackish distal half. Ventrally, the proximal half is yellow and the distal is brown. As with every Neotropical primate, it has forward oriented orbits and a complete postorbital bar. The skull is large, rounded and convex laterally. It has narrow gap between the incisive and canine. The dental formula is: incisive (2/2), pre-molars (3/3), and molars (3/3).

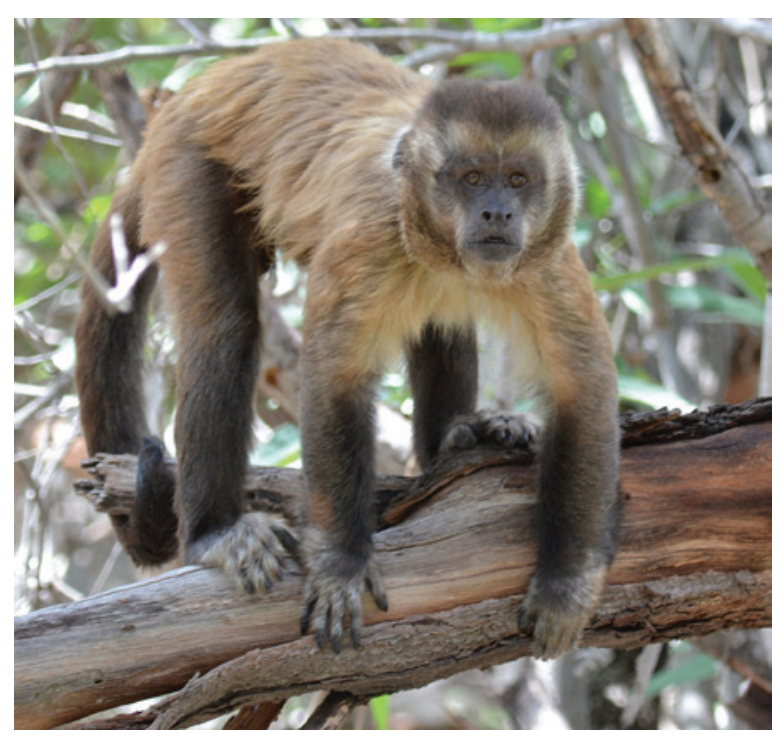

Figure 17. Cebus (Sapajus) libidinosus (Spix, 1823) (Photo: John Philip Medcraft).

Distribution: An endemic species of Brazil, widely distributed in Caatinga and Cerrado, to the north and to the west of the São Francisco River, to the west side of the Paraná River, and to the east side of the Tocantins River, Araguaia, and Paraguay (Hirsch 2010). On the Caatinga, C. libidinosus is restricted to areas with arboreal vegetation (Feijó and Langguth 2013).

Ethnozoological notes: There is little ethnozoological information about this species; nonetheless, it is known to be used as a protein source. The living animals can be kept by inhabitants of the region as pets (Figure 18). Twelve 
inhabitants of the Serra de Maranguape and nineteen of the Serra da Ibiapaba, two reminiscent of the humid forest of the state of Ceará, described the use of the species as food although it's rare, as the majority of the local population rejects the use of monkey meat as food, due to taboos associated with them. This same rejection was documented in 1789 by Christoph Gottlieb von Murr, who published notes made by the Jesuit, Johann Breuer, in the texts of Franz Veigl and Anselm Eckart, about the natural history of a Jesuit mission on the Serra da Ibiapaba (Papavero et al. 2011). In these notes, the Jesuit stated that the monkey's meat was low on fat and mildly pleasant to the indigenous habitants. Papavero et al. (2011) indicates that these descriptions are compatible with species of Cebus and the only existing species of the genus in Ibiapaba is Cebus libidinosus (Feijó and Langguth 2013).

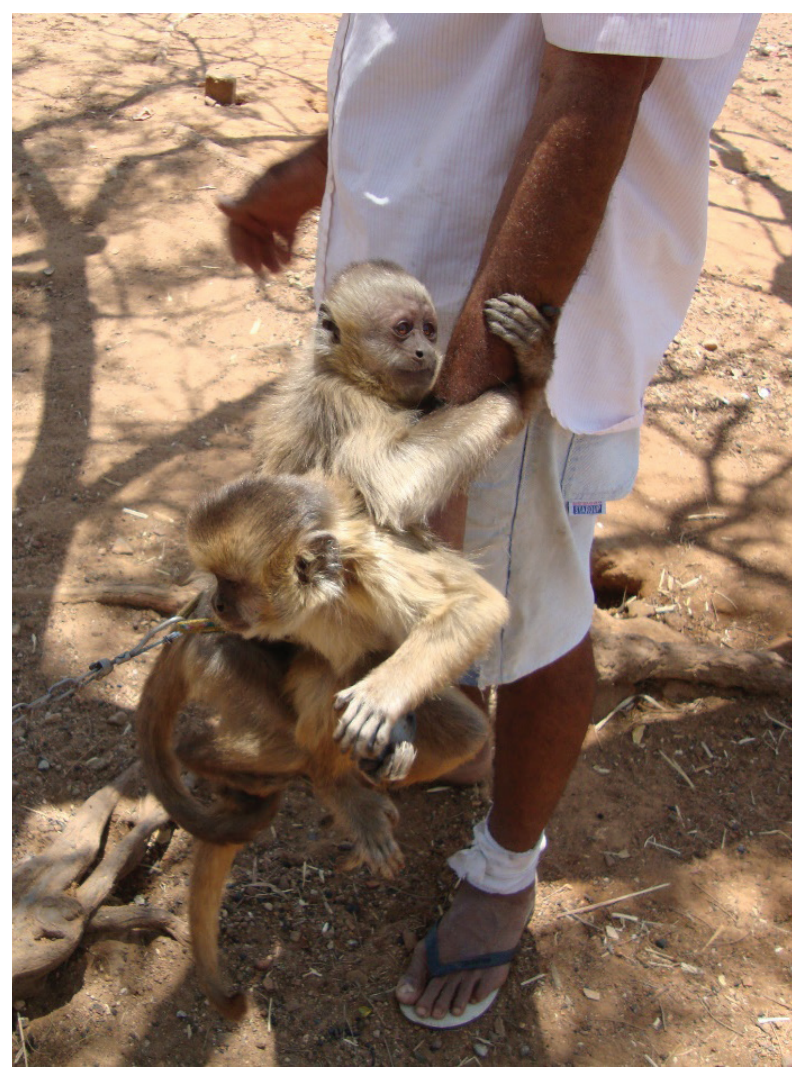

Figure 18. Cebus (Sapajus) libidinosus (Spix, 1823) kept as a pet in the semiarid area of Piauí State (Spix, 1823) (Photo: Raynner Rilke Duarte Barboza).
Callithrix jacchus Linnaeus, 1758 (Figure 19) - Common names: White tufted ear marmoset; Sagüi-de-tufo-branco.

Characteristics: This small-sized primate (head-body length: $205 \mathrm{~mm}$ ) is characterized by its lateral white tufts around the ears. The region around the mouth and chin is covered with short white hairs. The forehead has a white spot that is wider above the eyes. The dorsal fur of the neck is long, similar to a small mane, grey and black coloured. The general dorsal colour is a mixture of black, white, orange and yellowish. The posterior dorsal fur has four transversal bands. The pelage colour on the lateral of the body, limbs, and abdomen is similar the body's dorsum, but its transversal bands pattern are often hardly perceptible or non-existent. The pelage of the tail is ringed, greyish with alternated dark bands and light narrow bands. The skull has a relatively short rostrum, and a large, long braincase. The orbits are separated by a thin interorbital septum. The dental formula is i $2 / 2$ c $1 / 1$ p $3 / 3 \mathrm{~m} \mathrm{2/2}$.

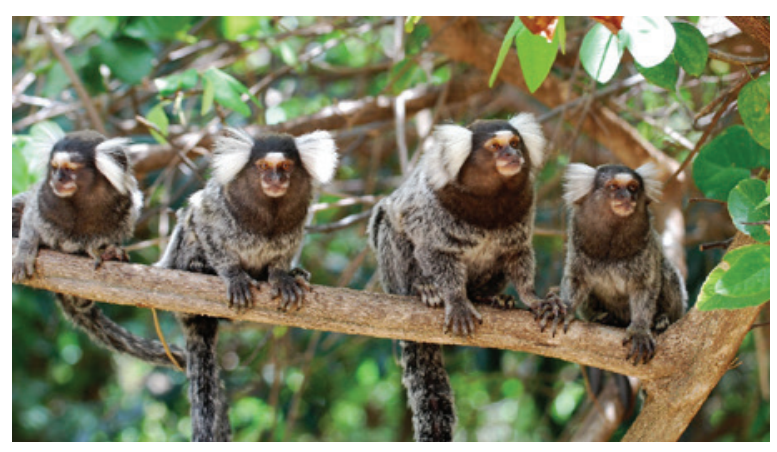

Figure 19. Callithrix jacchus Linnaeus, 1758 (Photo John Philip Medcraft).

Distribution: Originally distributed in the Caatinga and in the Atlantic Forest, north of the São Francisco River limited westwards by a tributary of the Rio Grande. The species was introduced beyond those limits, in the states of Sergipe, Bahia (Alonso et al. 1987), Rio de Janeiro (Ruiz-Miranda et al. 2000), Santa Catarina, and Buenos Aires, in Argentina (Rylands et al. 2009). This species is very abundant and widely distributed throughout the Caatinga (Feijó and Langguth 2013).

Ethnozoological notes: It is one of the most popular pets (Figure 20) amongst mammals. They 
can be kept chained, in cages, or they can be reared freely around the house, depending on the food given by their owners (Fernades-Ferreira 2011). Frequently, they are the target of wild animal smugglers that commercialize them as pets (Moura et al. 2012; Renctas 2001). Products derived from this species are also used in popular medicine in order to treat asthma, and umbilical hernia (Alves et al. 2013b).

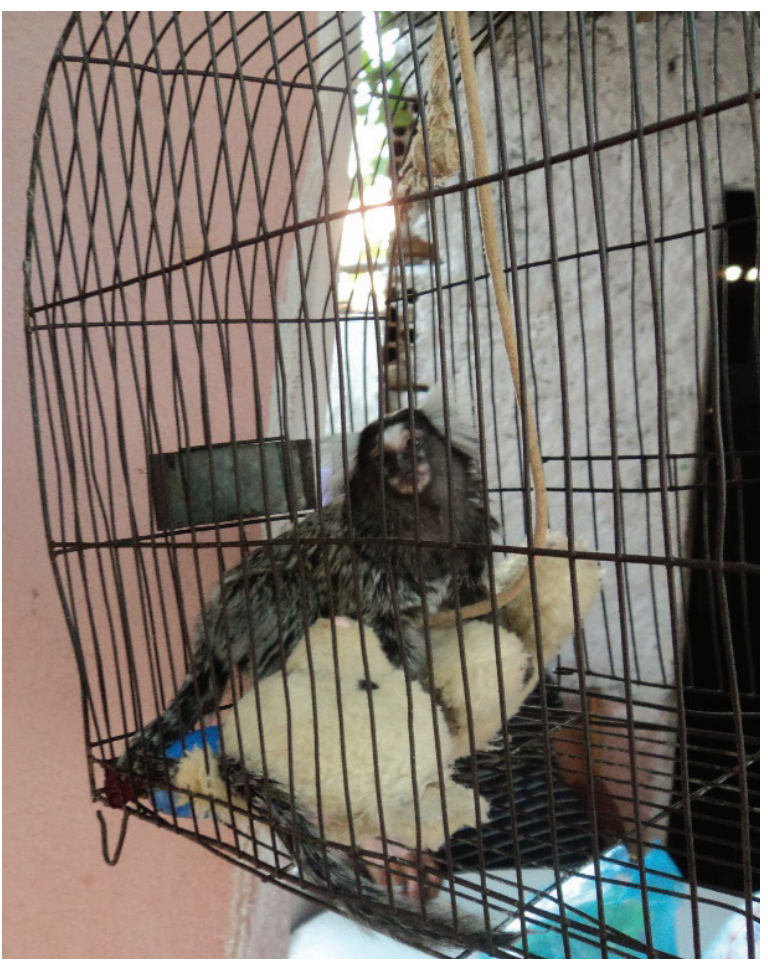

Figure 20. Callithrix jacchus (Linnaeus, 1758) kept as a pet in the semiarid area of Piauí State (Photo: Raynner Rilke Duarte Barboza).

Family Atelidae Gray, 1825

Alouatta belzebul (Linnaeus, 1766) (Figure 21) - Common names: Red-handed Howler Monkey, Guariba-de-mãos-ruivas

Characteristics: Medium-sized primate (headbody length: $458 \mathrm{~mm}$ ). The colour of body, head, limbs, and tail pelage is black. The feet, hands, and the distal part of the tail are reddish, and sometimes there are red tufts on the back. The male has a long black beard. The skull is wide, robust, and flattened dorso-ventrally. Laterally, the skull is unusual, compared to other primates, due to it has flattened dorsal profile. The mandible is robust and has a high coronoid process, which is a characteristic of the genus. It reflects the skull adaptation to lodge the sub-globular hyoid bone related to long-range vocalisation. The dental formula is $2 / 2$ c $1 / 1$ p $3 / 3 \mathrm{~m} 2 / 2$.

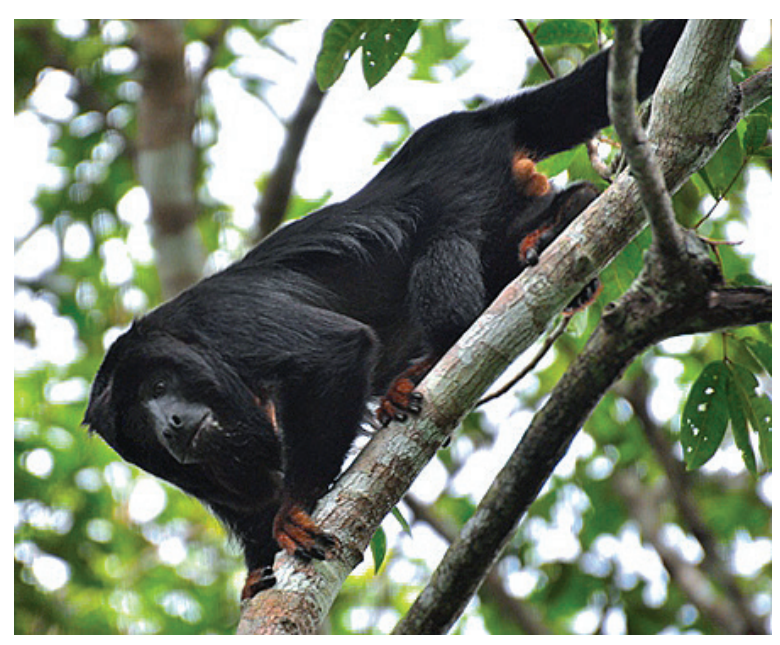

Figure 21. Alouatta belzebul (Linnaeus, 1766) (Photo: Caio Brito).

Distribution: $A$. belzebul is distributed along the northern region of the states of Maranhão, Piauí, and Ceará (Feijó and Langguth 2013; Gregorin 2006; Guedes et al. 2000). The species is restricted to mountain regions and arboreal vegetation, e.g. Serra de Ibiapaba and Serra de Guaraciaba do Norte, in the state of Ceará (Feijó and Langguth 2013).

Ethnozoological notes: In the Serra da Ibiapaba, 11 local residents reported the former use of this species as food. According to them, after the establishment of the Serra da Ibiapaba National Park, in 1979, and with the consequent enforcement of environmental legislation this practice fell in disuse (Hugo F. Ferreira, personal observation). The hunt of other species of the genus Alouatta for consumption has been shown in other studies (Crockett 1998; Peres 1997). It is also used in popular medicine, providing products to treat the following diseases: whooping cough, sore throat and asthma. The hyoid bone ("Adam's apple ") of the guaribamonkey is used in magic rituals to heal whooping cough (Pertussis) (Alves et al. 2013b). To achieve the cure, the sick person has to drink water using the globular shaped hyoid bone as a cup. This magic ritual is also related to other Alouatta species in different regions of Brazil (Alves and Rosa 2007a). 
Family Pitheciidae Mivart, 1865

Callicebus barbarabrownae Hershkovitz, 1990 (Figure 22)-Common names: Barbara Brown's Titi, Blond Titi Monkey, Guigó

Characteristics: Medium-sized primate species. General coloration is buffy to silver. The forehead, crown, throat, side of head, trunk and limbs are dominantly buffy, with the subterminal pheomelanic bands of hairs paler. Hands and feet are blackish, while ankles and legs are buffy. The tail is dominantly orange, upper surface of base paler or yellowish, hair bases eumelanic, remainder of tail entirely pheomelanic.

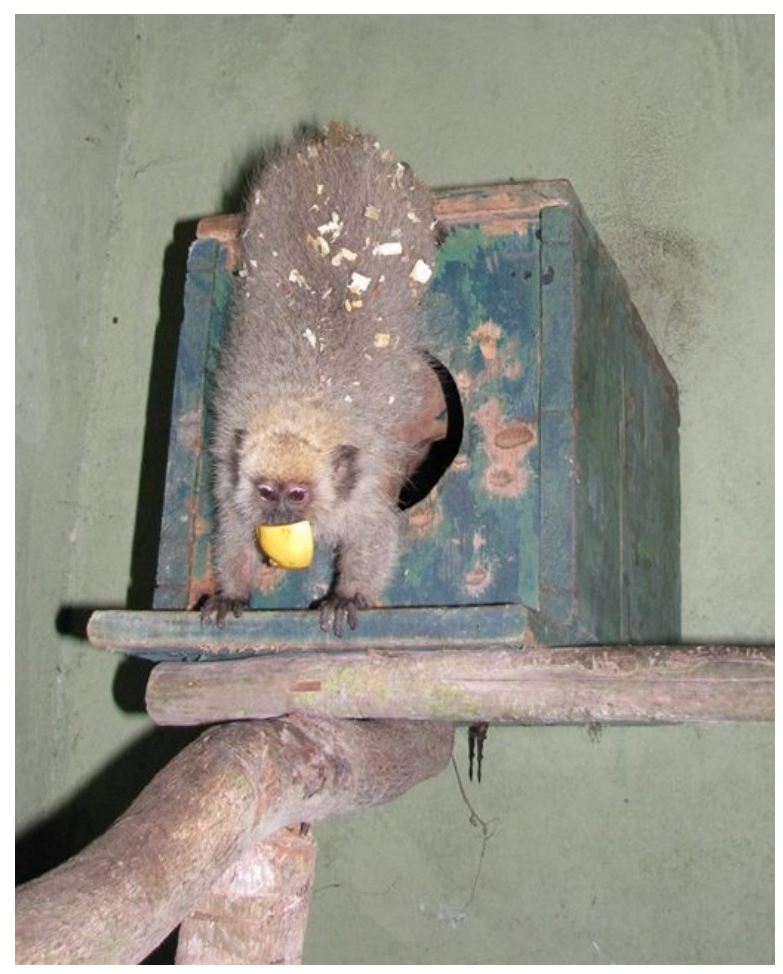

Figure 22. Callicebus barbarabrownae Hershkovitz, 1990 (Photo: Carla Aquino).

Distribution: Callicebus barbarabrownae appears to be endemic to the Caatinga of northern Bahia and western Sergipe, although few data are available for the northernmost portion of its range (Marques et al. 2013).

Ethnozoological notes: Hunting pressure needs to be ascertained, but it is probably moderate due to the small body size (Veiga et al. 2008).

\section{ORDER LAGOMORPHA}

Family Leporidae Fischer de Waldheim, 1817

Sylvilagus brasiliensis (Linnaeus, 1758) (Figure 23) - Common names: Forest Rabbit, Tapeti, Coelho

Characteristics: Medium-sized rabbit (headbody length: $363 \mathrm{~mm}$ ) with a soft and dense fur. The dorsal colour is yellowish mixed with dark brown. The periocular region is whitish extending towards the muzzle. It has a transversal pale strip on the throat forming an incomplete necklace. The ears are long and uniformly brown externally and white internally. The lateral region of the body is paler than the dorsum. The ventral pelage is white but the hairs have a grey base. The tail is short and reddish. The skull has a long robust rostrum. The premaxillary bones which form the lateral part of the rostrum are heavily fenestrated. The squamosal at the base of the zygomatic arch also has this characteristic but to a lesser extent. The incisive foramen is long, extending posteriorly until the beginning of the molariform series. The palate is very short. A long diastema separates the incisors from the molars. As all lagomorphs, S. brasiliensis has two incisive pairs, the first pair is long and the second is small, and right behind the first.

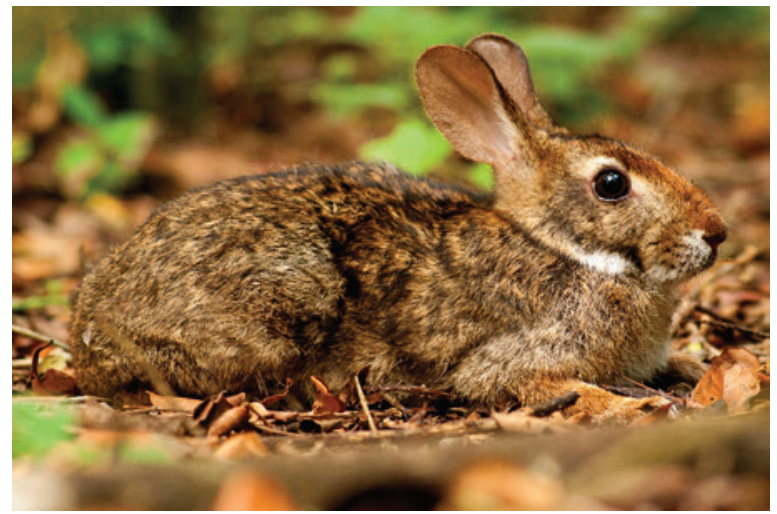

Figure 23. Sylvilagus brasiliensis (Linnaeus, 1758) (Photo: Ilan Ejzykowicz).

Distribution: Widely distributed in the Americas, from the Mexican east coast to the north of Argentina, and the south of Brazil (Diersing 1981). On the Caatinga it is found more 
frequently at the border of arboreal vegetation and the swamps (Silva-Júnior et al. 2005). Recently, Dantas et al. (2016) documented the first record of $S$. brasiliensis in Rio Grande do Norte state, Brazil (municipality of João Câmara), representing the northernmost report of this species for the Caatinga biome.

Ethnozoological notes: The species is used as a source of human food. Products derived from this species are used in popular medicine to treat diseases such as thrombosis, conjunctivitis, boils, and burns (Alves 2009, 2013b).

\section{ORDER CARNIVORA}

Felidae Fischer de Waldheim, 1817

Leopardus pardalis (Linnaeus, 1758) (Figure 24)

- Common names: Ocelot, Jaguatirica

Characteristics: Medium-sized feline species (head-body length: $700 \mathrm{~mm}$ ). The general background colour of the fur is yellowish brown, paler on the lateral parts and whitish or greyish on the abdomen. The pelage of the lips, chin, throat, and around the eyes is also white. The ears are covered with yellowish hairs on the internal sides of the pinnae and there is a large black central spot on the external side. The dorsal fur of the neck is short and forward oriented. On the shoulders, limbs, and on the body's sides there are four or five series of extremely irregular ocellated spots. These spots may be separated or fused forming oblique stripes along the body. The tail is relatively short if compared to the body. It shows over a light background big black spots which usually join in six to eight transversal stripes, the last ones are thick and sometimes connected.

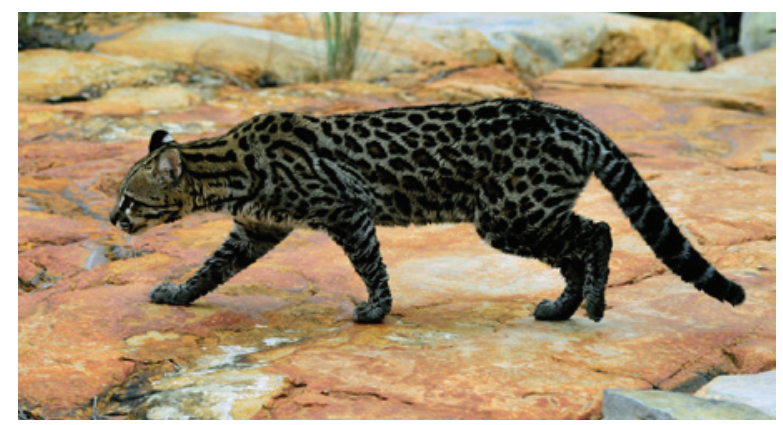

Figure 24. Leopardus pardalis (Linnaeus, 1758) (Photo: André Pessoa).
Distribution: L. pardalis has a wide distribution in the Americas, from the south of the United States, Mexico, and Central America extending until the north of Argentina (Murray and Gardner 1997). In the Caatinga, the records of this species are scarce, limited to or around the highland areas in places, with arboreal vegetation (Feijó and Langguth 2013).

Ethnozoological note: Hunting of this species is most related to conflicts with local human population, who aim to eliminate potential predators to their livestock in order to prevent economic loss. Furthermore, the ocelot suffers from diminishing numbers of its potential preys caused by habitat loss and hunting. Such problems affect several other animals which in turn affects the diet of this cat. With the reduction of its hunting areas, the ocelot tends to get closer to human populations, where it attacks domesticated animals, mainly poultry (Alves et al. 2009a; Barboza 2013).

When adults are killed due to the conflict, the cubs are often kept or sold as pets (Barboza 2013). For this reason, the species is included in the list of illegal international wild animal traffic.

Ocelot skin is commonly used by hunters as an ornament or commercialized. In addition, many hunters eat the flesh of ocelots, which is considered a very good meat. Ethnozoological informations from the states of Ceará $(49$ persons interviewed in Serra de Baturité, 10 in Granja, 17 in Itapipoca, 9 in Itapajé, 10 in Irauçuba), Pernambuco (5 persons interviewed in Escada, 3 in Serra Talhada) and Paraíba (12 persons interviewed in Areia) points out that the L. pardalis' skins as well as those of Leopardus tigrinus, Leopardus wiedii, Puma concolor, Panthera onca, and Eira Barbara had until the end of the 1980s a high value in national and international markets (Fernandes-Ferreira 2011). After the advent of a more strict legislation on wild animals trade (Fernandes-Ferreira and Alves 2014), this activity practically ceased.

This species can be hunted with dogs or shot at night with the aid of a spotlight, or, more rarely, when encountered accidentally during daytime. Individuals that adopt the habit of raiding a chicken roost or corral are most readily captured with traps. 
Leopardus tigrinus (Schreber, 1775) (Figure 25) - Common names: Little Spotted Cat, Oncilla, Gato-do-mato-pintado-pequeno

Characteristics: Small-sized cat (head-body length: $454 \mathrm{~mm}$ ). L. tigrinus has a background colour of the fur similar to the $L$. pardalis and $L$. wiedii. In the side of body, there are small incomplete dark rosettes, which not coalescing into oblique bands. The fur of dorsal neck is oriented backwards. The anterior end of the pre-maxillary bone is aligned to the anterior end of the nasal bone in L. tigrinus, what is not seen in the two other species.

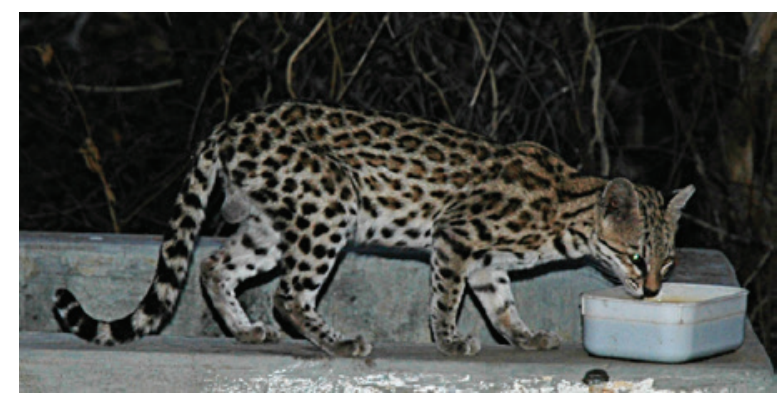

Figure 25. Leopardus tigrinus (Schreber, 1775)(Photo: Guilherme de Lima. ESEC Seridó, SerraNegra do Norte, RN).

Distribution: It is distributed throughout Centraland South America, from Costa Rica to Paraguay, and the North of Argentina (Husson 1978). L. tigrinus is the most common wild cat in the Caatinga, where it is widely distributed (Feijó and Langguth 2013).

Ethnozoological notes: The interactions of this species with the human population of the Caatinga are similar to those described for L. pardalis. In some areas of the Brazilian semiarid northeast, the attack of pets and/or livestock is the main cause of killing this species. The skin is used ornamentally and the meat is eaten (Alves et al. 2009a). Moreover, they can be reared as pets (Figure 26). There is a record of two spotted cat babies reared as pets in the rural zone of a the Lagoa city, Paraiba State, in 2012 (Vasconcelos-Neto 2013).
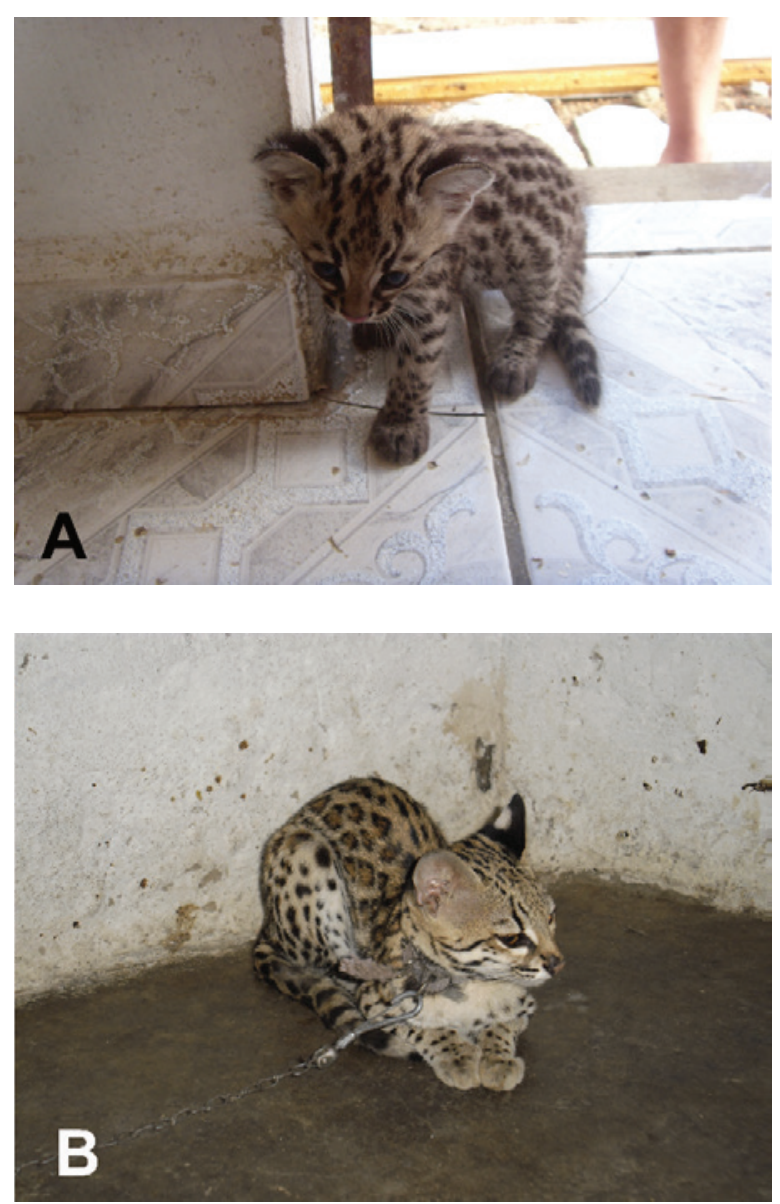

Figure 26. Specimens of Leopardus sp. kept as pet in municipalities of northeastern semiarid (Photo: A Raynner Rilke Duarte Barbosa and B- Gleidson Lima).

Leopardus wiedii (Schinz, 1821) (Figure 27) Common names: Margay, gato-maracajá, Gatodo-mato

Characteristics: Small-sized cat (head-body length: $405 \mathrm{~mm}$ ). The pelage colour of this species is similar to that of the L. pardalis and L. tigrinus, being distinguished in the following features: $L$. wiedii is smaller and its tail is proportionally longer and thicker than that of $L$. pardalis. The fur on the back of the neck is forward oriented, while in $L$. tigrinus is oriented backwards. The spots in the side of the body are well-marked and coalescent into oblique bands, with the edge darker and thicker than L. tigrinus. 


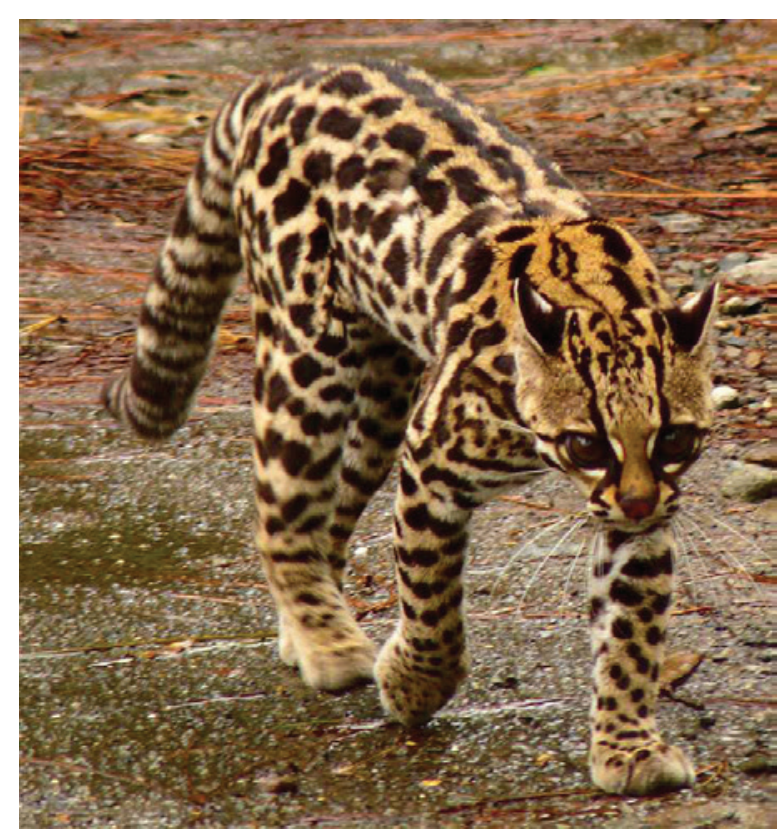

Figure 27. Leopardus wiedii (Schinz, 1821) (Photo:https://upload.wikimedia.org/wikipedia/ commons/8/8a/Tika2009Jan24.jpg).

Distribution: The species is distributed from northern Mexico through Central America, Venezuela, Ecuador, Bolivia, and Colombia through Amazonia to the Guyanas, and Brazil southwards to Paraguay northern of Argentina, and Uruguay (Oliveira 1998). There are few confirmed reports of this species in the Caatinga and it is likely that its current existence in the area is limited to highlands with preserved forests within of the semi-arid region.

Ethnozoological notes: As with other aforementioned species of the genus Leopardus, this species is often involved in conflicts with humans because they attack pets or livestock. The fur of this species is used as an ornament and when captured, they can be kept or commercialized as pets.

Puma concolor (Linnaeus, 1771) (Figure 28) Common names: Cougar, Suçuarana, Onça-parda, Onça-bodeira

Characteristics: $P$. concolor is the second largest feline species in Brazil (head-body length: $1520 \mathrm{~mm}$ ). The colour of the back is uniform and varies from light brown greyish to a reddish brown. The sides of the muzzle and the tip of the tail are blackish brown or black. The chin, the anterior part of the muzzle and the ventral regions of the body are white or cream white. The ears are small, rounded, short, and black on the external part of the pinnae, which may bear a light spot in the middle. The tail is long, furry, and black at the tip. The skull is large with a short and wide rostrum. The orbits are large, rounded, and oriented forward. The interorbital region is narrower than the post-orbital region and the braincase is rounded. The dental formula is $i 3 / 3$ c $1 / 1 p 3 / 2 \mathrm{~m} 1 / 1$.

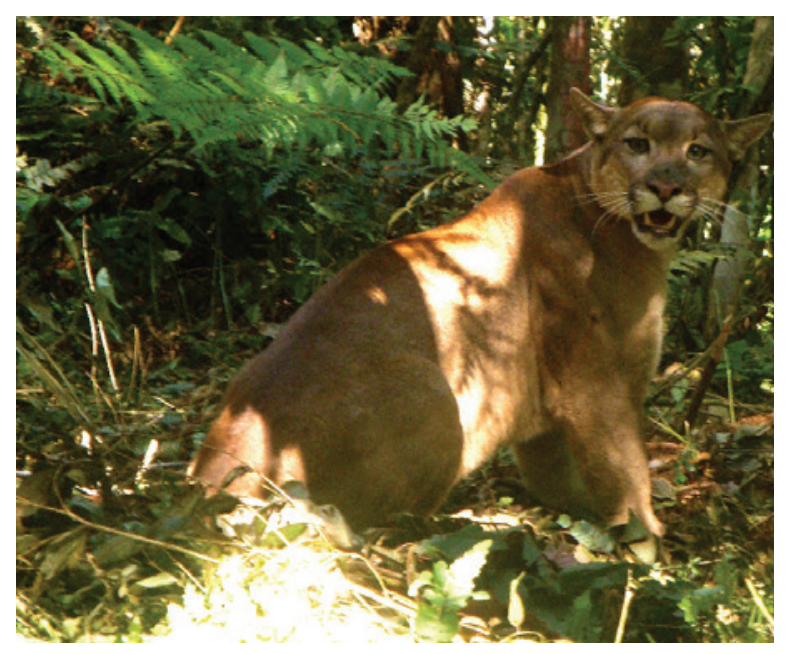

Figure 28. Puma concolor (Linnaeus, 1771) (Photo: Tarcizio Antônio Rêgo de Paulo).

Distribution: This species occurs from southern Canada through Central America, to southern Chile, and Argentina (Young 1946). However, due to hunting and deforestation the puma populations are limited to the mountain ranges or areas sparsely occupied by man (Currier 1983; Young 1946).

Ethnozoological notes: Historically the species has been persecuted in retaliation for livestock predation, and due to fears that they pose a threat to human life (Caso et al. 2008). As P. concolor is a large sized species compared to the other felines described above, its prey includes large to medium sized wild mammals, as well as sheep, goats, pigs, young horses and donkeys. The conflicts with humans and habitat loss, are the main causes of population reduction in the Caatinga, were hunters rarely report encounters with cougars. In Serra de Baturité, Ceará state local inhabitants report the hunting of this species in low altitude areas of the 
massif in order to control them. In the municipality of Caridade, in the same state, remains of a specimen killed in 2010 (Fernandes-Ferreira 2011) were collected. Old hunters in the Caatinga region reported that they were hired to capture the cubs jaguars and $P$. concolor in order to supply circus needs or to sell to private breeders (Barboza 2013).

As this species is considered dangerous and difficult to hunt, parts of this animal are kept to be displayed as hunting trophies. It is not rare to find hunting photos of cougars in the houses of old hunters, who show them off proudly (Figures 29 and 30). The species provides several products to local hunters; the main one is the skin, which has a high market value, and the meat that can be used as food.

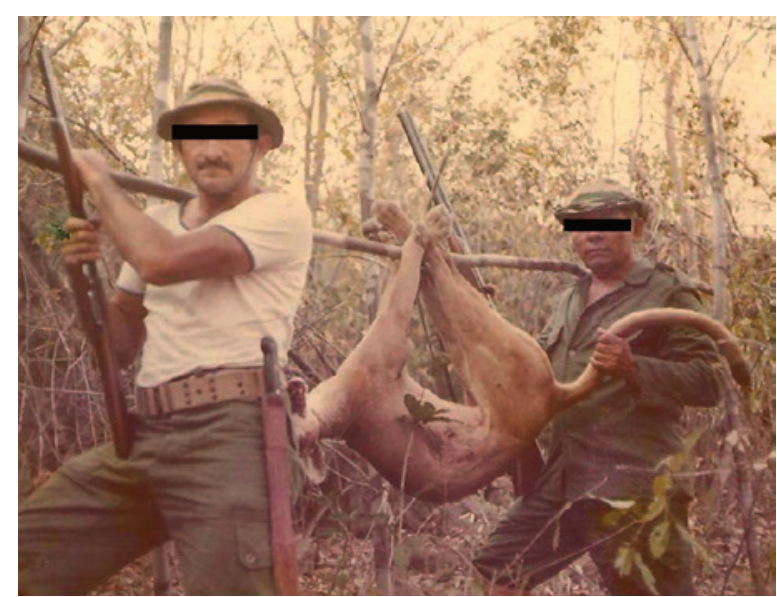

Figure 29. Hunters exhibiting a captured and killed specimen of Puma concolor (Linnaeus, 1771) held in the 70s. Personal photograph of semiarid hunters in courtesy to Raynner Rilke Duarte Barboza.

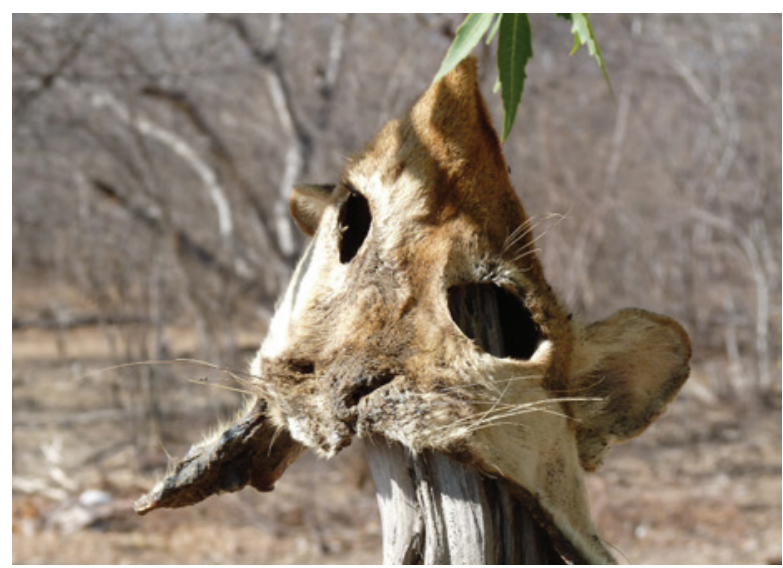

Figure 30. Skin of the cephalic region of Puma concolor (Linnaeus, 1771) displayed by hunters as a trophy (Photo: Hugo Fernandes-Ferreira).
Puma yagouaroundi (É. Geoffroy 1803) (Figure 31) - Common names: Jaguarundi, Gatomourisco, Gato-vermelho, Gato-roxo, Gato-azul

Characteristics: A medium-sized felid (headbody length: $576 \mathrm{~mm}$ ), $P$. yagouarondi has a uniform pelage colour varying from blackish brown, greyish to a distinct yellowish. The medial dorsal region is darker than the sides and the belly. The head is dorsoventrally flattened in the interorbital region differing from other Neotropical felines where this region is arched. The chin and the intermandibular regions are white in the yellowish individuals. The skull has a short rostrum. The supraorbital border extended forward as a ridge throughout the rostrum down to the nasals. The braincase is long taking more than half of the skull. The lateral dorsal profile appears flattened. The species is easily distinguished from the other cats of the genus Leopardus by its uniform dorsal colour and by its straight skull profile. The dental formula is $i 3 / 3$ c $1 / 1 p 3 / 2 \mathrm{~m} 1 / 1$.

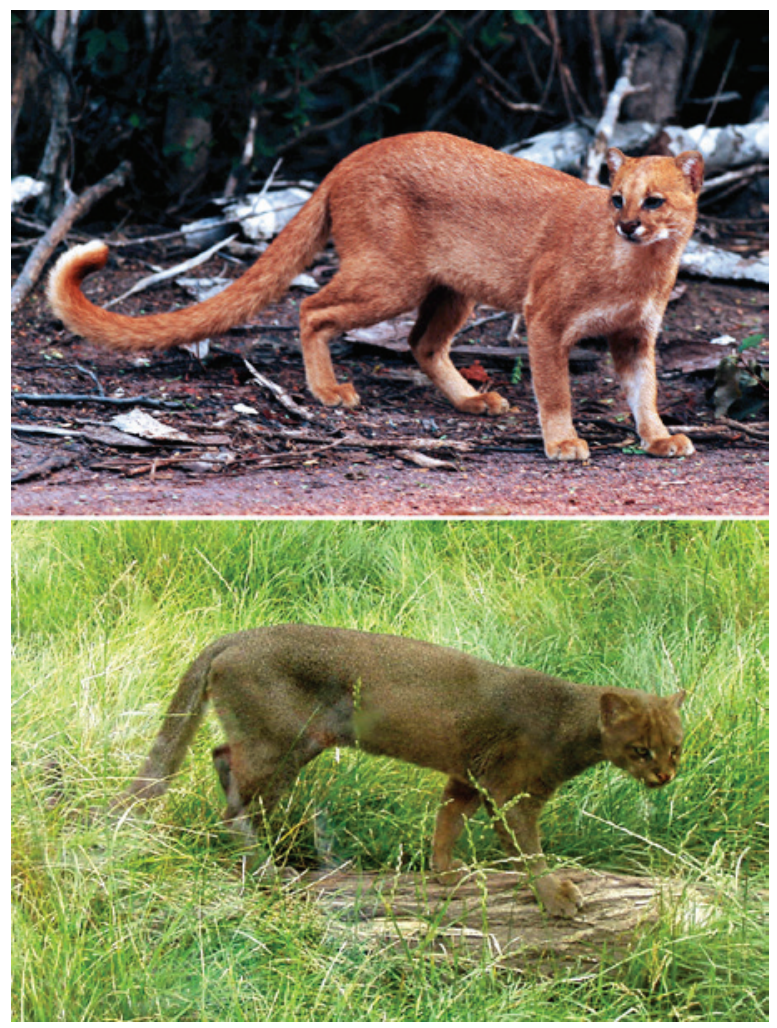

Figure 31. Puma yagouaroundi (É. Geoffroy SaintHilaire, 1803) in yellowish and grayish pelages. Photos: André Pessoa (above) and below "Herpailurus yagouaroundi" by Bodlina - Own work. Licensed under CC BY 3.0 via Commons. 
Distribution: Puma yagouarundioccurs from the south of the United States, through Mexico, Central and South America, Brazil (in the whole territory), and in the central region of Argentina (Husson 1978; Oliveira 1998). P. yagouarondi is widely distributed in the Caatinga biome (Feijó and Langguth 2013).

Ethnozoological notes: The interactions between this species and inhabitants of Caatinga are similar to that described for the other small cat species. Recent ethnozoological studies reveal that the species is frequently considered a livestock predator (Figure 32) (Alves et al. 2012a, 2009a; Barboza 2013; FernadesFerreira 2011). Repeated attacks on livestock often induce farmers to hire local hunters to track and shoot down jaguarundis (Alves et al. 2009a; Mendonça et al. 2011). These last authors registered a single hunter who confirmed 200 kills in his lifetime. Even though conflict is the main reason for the killing of this species, its meat can be consumed and its skin can be used for ornamental objects or hunting trophies (Alves et al. 2012a, 2009a; Barboza 2013).

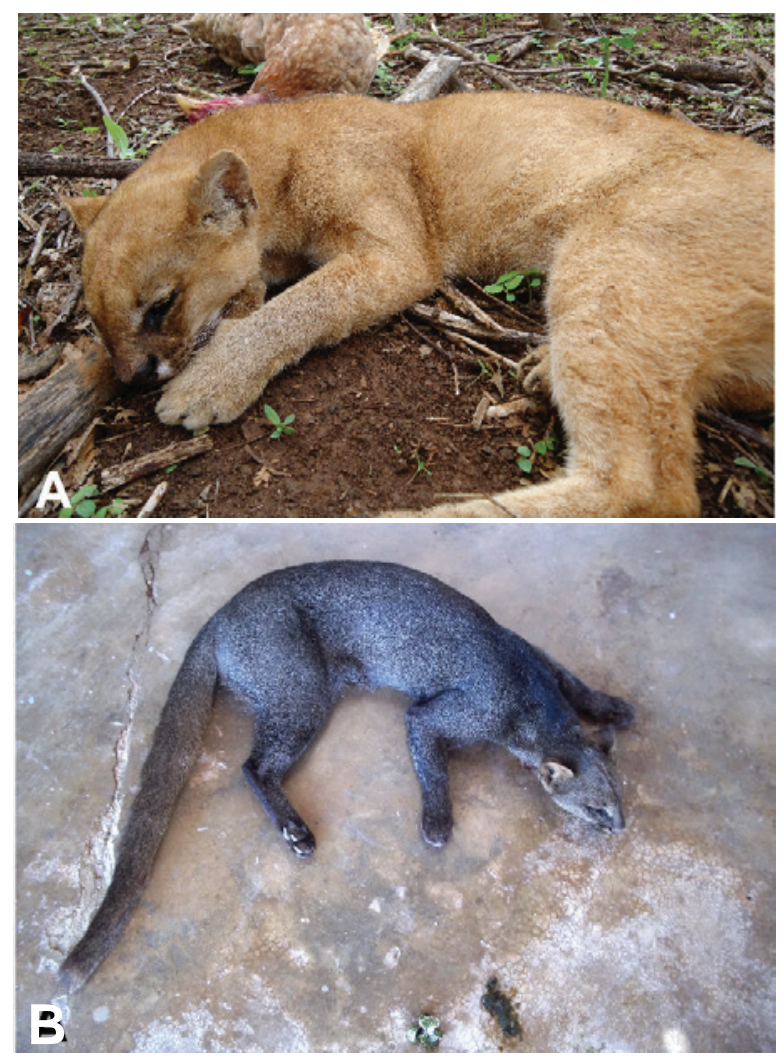

Figure 32. Herpailurus yagouaroundi (E. Geoffroy Saint-Hilaire, 1803) killed by retaliation due attacks on poultry (Photos: Raynner Rilke Duarte Barboza - A and B).
Panthera onca (Linnaeus, 1758) (Figure 33). Common names: Jaguar, Onça-pintada

Characteristics: The jaguar is the largest felid in the Americas; with a length from head to tail varying from 1.57 to 2.41 meters. The colour of the dorsal background and of the sides is yellow. The external surface of the pinnae is black with a big central yellow spot. The neck and the dorsum are covered with blackish rosettes. On the dorsum there are large elongated black spots. The external parts of the limbs have rosettes on the proximal region which are gradually replaced by small dots on the distal region. The jaguar tail has same background colour as the dorsum in its proximal region while the distal part is paler. The ventral surface of the body and the internal part of the limbs are whitish or cream on the background, and densely covered by big black spots. The skull is robust and has a short rostrum. The lateral profile of the skull is convex. The dental formula is i $3 / 3$ c $1 / 1 \mathrm{p} 3 / 2 \mathrm{~m} \mathrm{1/1}$.

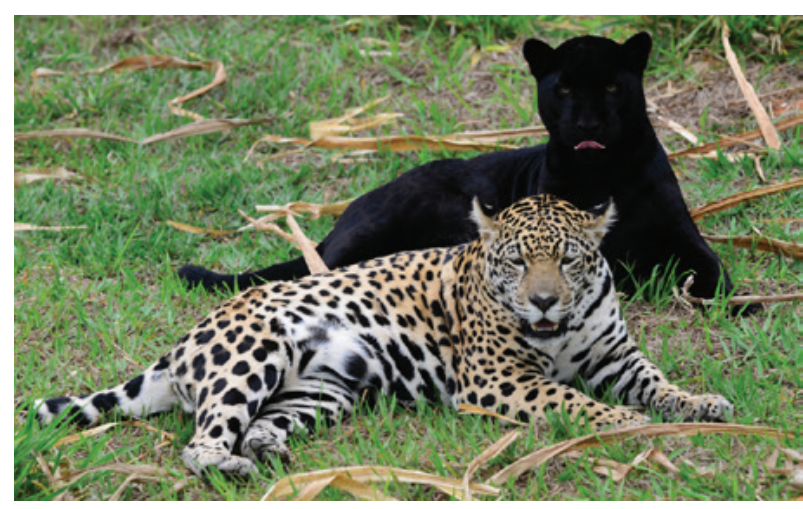

Figure 33. Panthera onca (Linnaeus, 1758) in yellowish and black coloured fur (jaguar) (Photo: André Pessoa).

Distribution: The original distribution of the jaguar extended from southeastern United States to southern Argentina. However, as with $P$. concolor, hunting and habitat destruction have dramatically decreased its distribution. This species is considered extinct in the U.S., El Salvador, Uruguay, and on the most Brazilian Atlantic forest (Brown 1983; Seymour 1989). In the Caatinga, the scarce recent records are limited to the western region of the biome, e.g. Serra da Capivara on the southeast of the state of Piaui and on the northwest of Bahia state, in the area known as Boqueirão da Onça (Brandão et al. 2009; Feijó and Langguth 2013). 
Ethnozoological notes: As discussed above, the practice of eliminating carnivores for conflict reasons is common in Caatinga' $s$ history of human occupation. The jaguar has been persecuted historically, mainly due to its potential predation on domestic mammals and the risk it presents to people. Furthermore, as they are predators of several game vertebrates of the Caatinga, the jaguar is seen as a competitor by hunters. As a result of these factors and due to the habitat loss by deforestation in the Caatinga, the species is one of the most endangered felids of the biome.

Old reports reveal that these animals were frequently persecuted by hunters, motivated by their beauty and the risk that they represented to the hunter (Figure 34). It is regarded as one of the most precious hunting trophies, conferring a distinguished status to hunters who kill the jaguars (Barboza 2013). Modercin (2010), in a research in the semiarid of the state of Bahia, recorded accounts of numerous Indigenous experienced hunters of the Pankararé tribe paid by farmers to slaughter jaguars that preyed on cattle. The human conflict with the Panthera onca is extensive in various Brazilian biomes (Conforti and Cesar 2003; Palmeira and Barrella 2007; Palmeira et al. 2008; Zimmermann et al. 2005) as well as in other Latin American countries (Altrichter et al. 2006; Polisar et al. 2003).

The fur of this species can be used as an adornment or as hunting trophies. In addition, the meat can also be consumed as food.

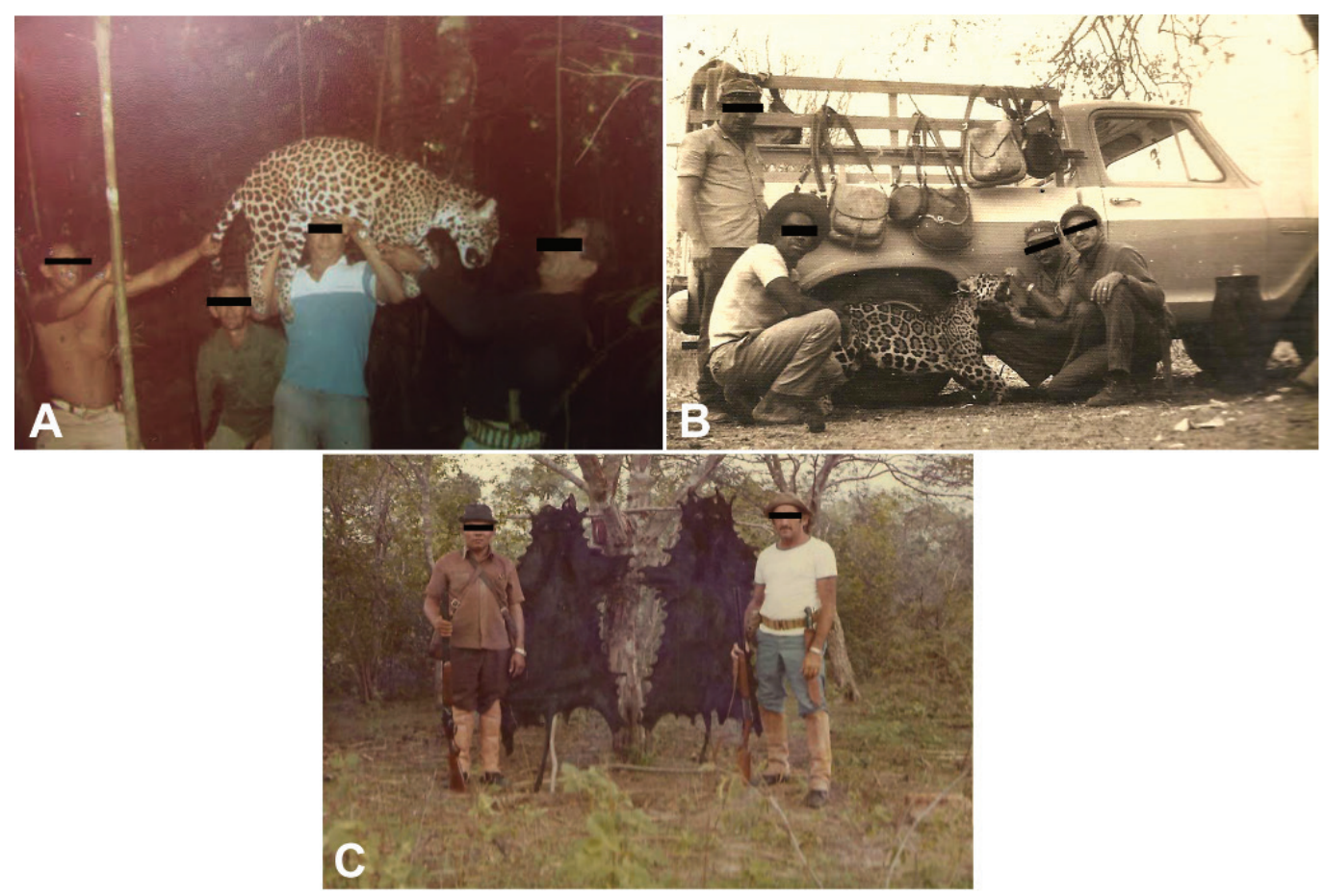

Figure 34. Hunters displaying jaguar skins (first photo in left, top) and jaguar specimens in hunting expeditions in the 60 s and 70s. Personal photographs of semiarid hunters in courtesy to: Hugo Fernandes-Ferreira $(A)$ and Raynner Rilke Duarte Barboza (B and C).

Family Canidae Fischer, 1817

Cerdocyon thous (Linnaeus, 1766) (Figure 35) - Common names: Crab-eating fox, Raposinha, Cachorro-do-mato

Medium-sized species (head-body length: $573 \mathrm{~mm}$ ) among the carnivores, it has a greyish colour on the head and dorsum, with a darker band extending from neck to the base of the tail. The ears are reddish on the proximal half, and brownish on the distal half. The sides of the body have a greyish yellowish colour gradually changing to yellowish or whitish in the belly. The tail has long fur and is of the same colour as the body, sometimes it 
has a black dorsal strip and always a black tip. The skull has a long, robust and anteriorly narrowed rostrum. The zygomatic arch is wide, robust and converges anteriorly. The postorbital region is larger than the interorbital region. The braincase is wide and oval, representing less than half of the total skull length and without a sagittal crest. The mandible is robust, and its lower edge is straight with a rised angular process. The dental formula is i $3 / 3$ c $1 / 1$ p $4 / 4$ m 3/3.

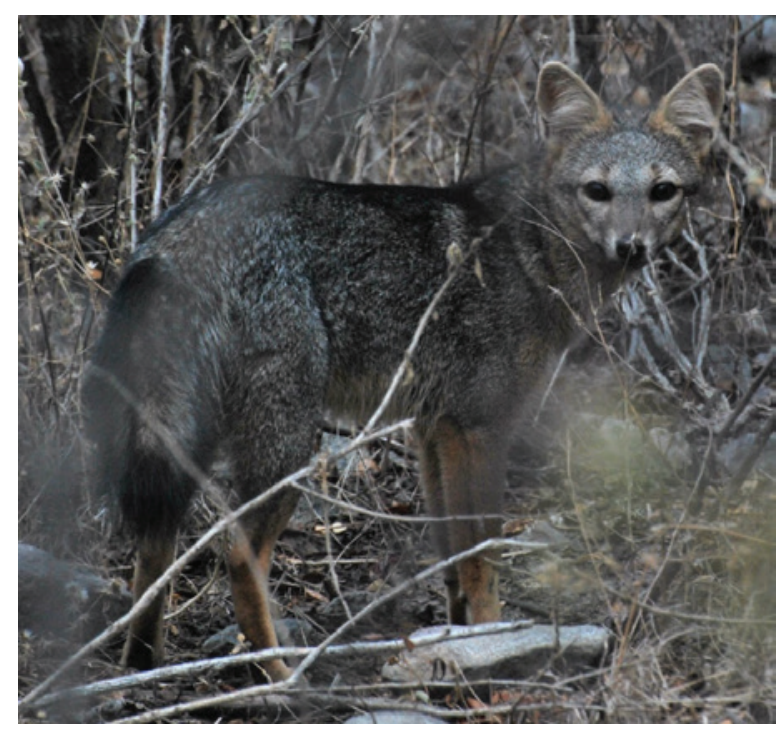

Figure 35. Cerdocyon thous (Linnaeus, 1766) (Photo: John Philip Medcraft).

Distribution: C. thous is endemic to South America and is found from the north of Colombia, throughout Venezuela, Guiana and Suriname the Amazon River delta (not in the central Amazonian region) and the east side of the Pará state, continuing along eastern, central, and southern Brazil. It's also found in southeastern Bolivia Paraguay, Uruguay, and Argentina (Langguth 1969, 1975). It is widely distributed in the Caatinga (Feijó and Langguth 2013) and also occurs in the Atlantic Forest, Pantanal, Pampas, and Cerrado biomes.

Ethnozoological notes: This species is also affected by conflict with humans because it predates on livestock and feeds on crops (Figure 36). In a study with hunters in the semi-arid region of Paraiba state (Mendonça et al. 2011), personal accounts reported foxes invading corn crops to eat corn heads, causing much damage. Rocha et al. (2004) confirmed the presence of this item in the diet of Cerdocyon thous.
As well as this plant, the animal can eat fruits such as watermelons and cucumbers. As the foxes are considered an opportunistic species, they survive in degraded and anthropic areas (Facure and MonteiroFilho 1996; Langguth 1975), by taking advantage of several alimentary resources provided by human activities. Although the main reason of crab-eating fox hunting is direct conflict; the secondary products of the crab-eating fox as the fat, the fur, or the tail, can be used in traditional medicine (Alves 2009, 2013b).

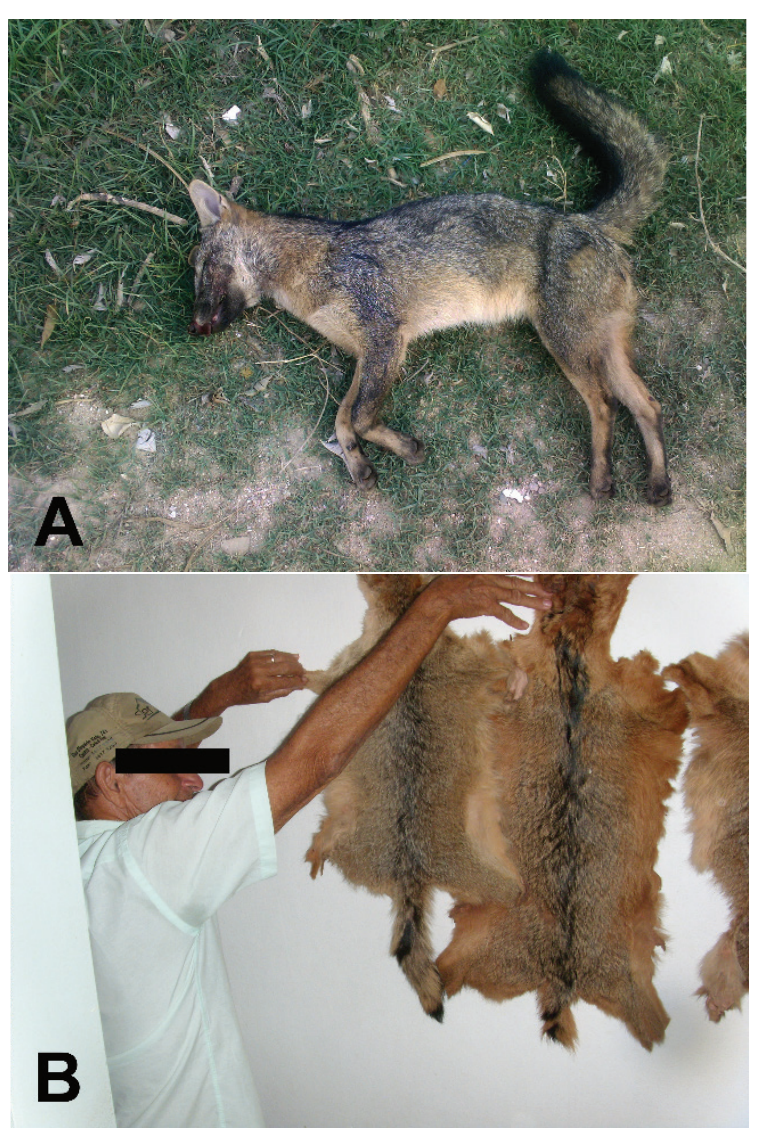

Figure 36. Cerdocyon thous (Linnaeus, 1766) killed in order to prevent attacks to poultry $(A)$ and, animal leather, a typical product used by the residents of the Brazilian semiarid region (B). Photos: Raynner Rilke Duarte Barboza.

\section{Family Mustelidae Fischer, 1817}

Eira barbara (Linnaeus, 1758) (Figure 37) Common names: Tayra, Papa-mel, Irara

Characteristics: This carnivore is a mediumsized species (head-body length: $531 \mathrm{~mm}$ ). One 
of its striking features is the clear difference from the colour of head and neck, which are yellowish or grayish, in relation to the body. The muzzle has a short dark fur. The ear is short, rounded, and of the same colour of the head. The dorsal surface of the body is, usually, of a uniform dark brown colour which extends through limbs and tail. In the ventral surface of the body has, as a diagnostic trait, a transversal yellow, orange, or whitened irregular spot on the throat. The rest of the abdomen has the same colour of the back or may be a slightly paler. The skull has a long and wide rostrum and nasals. The orbits are small and placed on the anterior third of the skull. The braincase is wide and low, occupying about half of the skull. The palate is long and extended well behind the molars as much as the length of the molariform series. The mandible is short with a straight lower edge. The dental formula is: i $3 / 3$ c $1 / 1$ p 3/3-4 m 1/1-2.

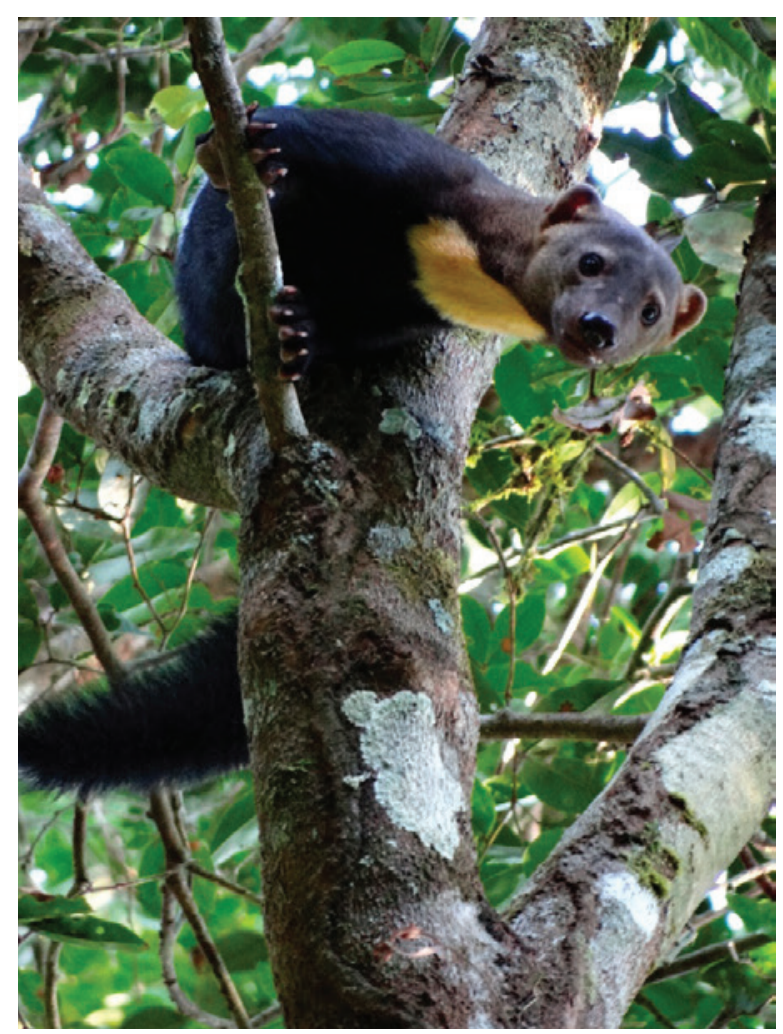

Figure 37. Eira barbara (Linnaeus, 1758) (Photo: Bruno Pinotti).

Distribution: E. barbara occurs from Vera Cruz, eastern Mexico, over all Central America, and east of the Andes, to the north of Argentina (Husson
1978). There are scarce records of this species in the Caatinga. Nonetheless, as with some felines, it is possible to assume that the E. barbara is limited to regions of humid forests that were not widely anthropized.

Ethnozoological notes: There are scarce ethnozoological records of this species in the Caatinga' domain. Despite this, four hunters from the municipality of Ribeirão, in the state of Pernambuco confirmed that E. Barbara skins had high value in national and international market and that captures for this purpose was common throughout the region in the early 1990s (Hugo F. Ferreira, personal report). Fernandes-Ferreira (2011), mentions that this species was also used by humans as food, although even in other parts of Brazil, the species has little importance as game. Emmons and Feer (1997) point out that this species suffers huge hunting pressure in the humid neotropical forests. Naughton-Treves et al. (2003) reports that the species is hunted in Amazonia.

Galictis cuja (Molina, 1782) (Figure 38) Common names: Lesser grison, Furão

Characteristics: A Small-sized carnivore (headbody length: $300 \mathrm{~mm}$ ) with a black head. It has a "U" yellowish coronal strip opened to the back and passing across the head above the eyes and sides of the neck. From the back of the head backwards along the neck and body and the base of the tail the fur has a greyish appearance. As a result, the head is tricoloured: black at the front, yellow or whitish in the coronal strip and grey at the back. The black of the head extends ventrally through the whole body, including the limbs. The limit between the dorsal and ventral colours is well defined. The ears are small and rounded with yellow fur internally and externally. The tail has a long fur and is of a similar colour to the dorsum of the body, whereas the tip is usually yellow. The skull is short. The orbit is small, located on the anterior third of the skull. The braincase is flattened. The palate is long, and extends behind the molars for a distance a little smaller than the size of the molariform series. In a lateral view, the dorsum of the skull is almost straight, descending softly until the rostrum level. The dental formula is i $3 / 3$ c $1 / 1$ p $3 / 3 \mathrm{~m} 1 / 2$. 


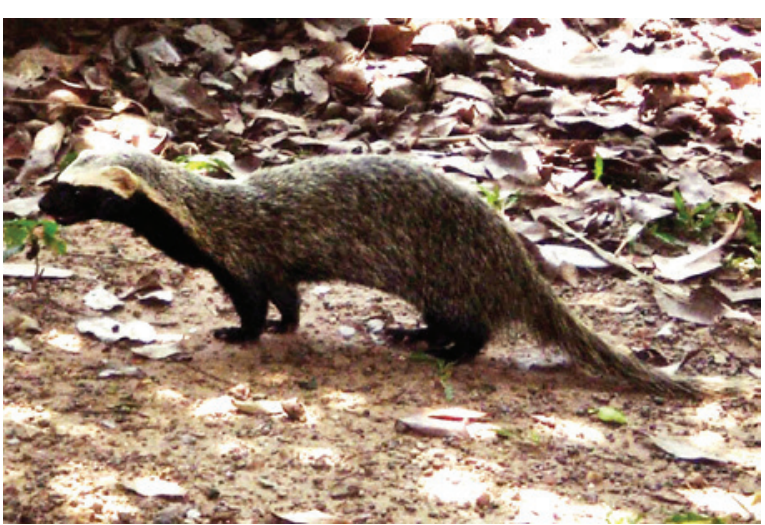

Figure 38. Galictis cuja (Molina, 1782) (Photo: Carolina Carvalho Cheida).

Distribution: G. cuja is found in the south of Peru, east of Bolivia, Chile, Uruguay, Argentina, and eastern parts of Brazil (Yensen and Tarifa 2003). This species is widely distributed in the Caatinga (Feijó and Langguth 2013).

Ethnozoological notes: Grisons are not important as game in the semiarid region, but the animal's skin can be used ornamentally. The species can be taken as pets, mainly if captured while they are babies, when it becomes easier to keep them in captivity. It can also be used in popular medicine.

Family Mephitidae Bonaparte, 1845

Conepatus amazonicus (Lichtenstein, 1838) (Figure 39) - Common names: Striped hog-nosed skunk, Gambá, Ticaca, Jeritataca

Characteristics: A medium-sized species (head-body length: $378 \mathrm{~mm}$ ). The body, limbs, and muzzle are black. The head has short fur and the rhinarium is surrounded by long whiskers. Two white and large stripes, that are united in the head, run over the dorsum of the body. The ears are relatively small and have white tufts on the base. The tail is furry; its fur is longer than that of the dorsum. The tail is black on the basal third, and all the rest is dominated by long white hairs mixed with some black that extend to the tail's tip. The limbs are short and the manu have well developed claws. The abdomen has black fur as does the dorsum, but it is shorter and thicker. The skull has a short and large rostrum. The braincase is wide and occupies more than half the size of the skull.
The palate is rectangular and wide, extending a slightly further backwards than the last molar. Its posterior edge has a medial process of with a sharp tip. Behind the incisive foramina there is a medial palatine foramen. The dental series is short and the only upper molar is wide. In lateral view, the dorsal profile of the skull is flattened. The anterior end of the pre-maxillary extends far beyond the nasal bone. The nasal opening is wide and oblique. The dental formula is: i $3 / 3$ c $1 / 1$ p 2/3 $\mathrm{m} 1 / 2=32$.

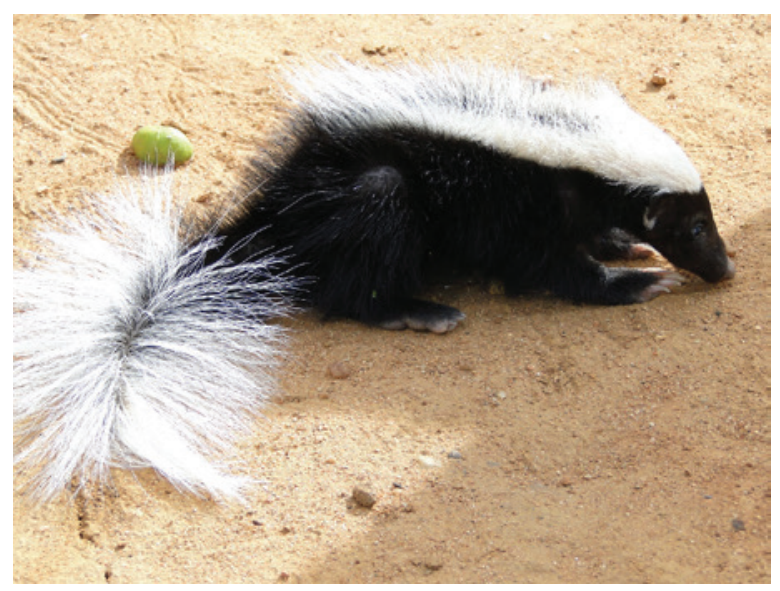

Figure 39. Conepatus amazonicus (Lichtenstein, 1838) (Photo: Wedson Medeiros Silva Souto).

Distribution: $C$. amazonicus is found from the state of Maranhão to the state of Minas Gerais (Cheida et al. 2006; Eisenberg and Redford 1999). The distribution of this species in the Caatinga is limited to open areas (Feijó and Langguth 2013).

Ethnozoological notes: The species has a bad reputation in some localities, mainly because it has two perianal anal glands which are responsible for the production of a volatile yellow substance with a pungent odour projected off the body (Eisenberg and Redford 1999; Emmons and Feer 1997). When this animal is threatened, it elevates the tail and squirting this liquid on the predator. The substance can be squirted for a distance of up to 2 meters and it remains active for a long time. The liquid provokes irritation on the mucous membranes, dizziness, and sickness (Cavalcanti 2010). Nevertheless, recent ethnozoological studies reveal that the skunk is one of the main mammals of alimentary importance in the Caatinga. Hunters 
remove its anal glands and consume the meat which is very appreciated (Alves et al. 2012a, 2009a; Barbosa et al. 2011). In popular medicine, the meat; urine, bone, and fat can be used to treat anaemia, earache, rheumatism, leg pain, backache, articulation pains, asthma, and sight problems (Alves 2009; Alves et al. 2007).

\section{Family Procyonidae Gray, 1825}

Nasua nasua (Linnaeus, 1766) (Figure 40) Common names: Brown-nosed coati, Quati.

Characteristics: Medium-sized species (headbody length: $513 \mathrm{~mm}$ ). There is a large individual variation in the fur colour in animals of the same locality. Some coatis are predominantly black, and others are yellowish or greyish. There are three white spots around each eye: one is above, another is under, and the last between the eye and the ear. The external pinna is uniformly dark and the internal part is outlined by a white strip. The ventral surface of the body is paler than the dorsum. The tail has dark brown or black rings alternated with yellow or reddish rings. The skull has a triangular shape, seen from above. The rostrum is long, narrow, and distinctly constricted posterior to the canines. The braincase is wide and short, it is less than half the total skull length. The adult males have a high sagittal crest. The palate is long, extends beyond the last molar over a distance similar to that of half the dental series. Behind the posterior end of the incisive foramina there is a medial palatine foramen. The dental formula is i 3/3 c 1/1 p 4/4 m 2/2.

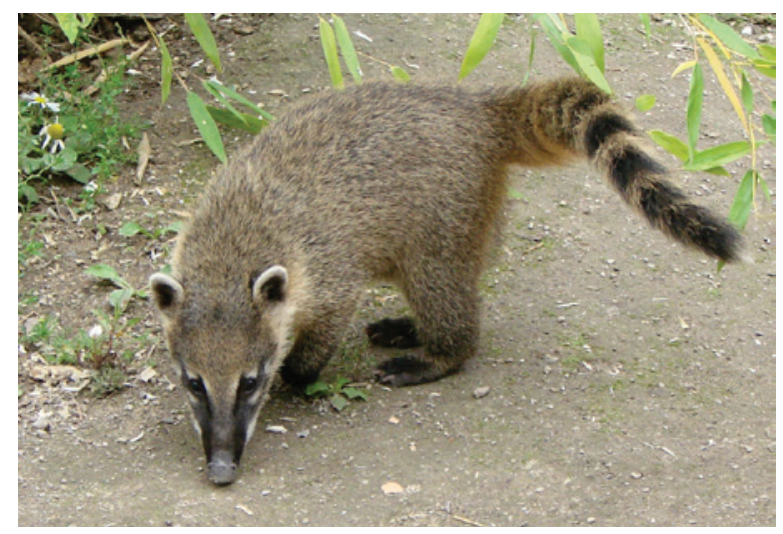

Figure 40. Nasua nasua (Linnaeus, 1766) (Photo: "Coati roux Amiens 4" by Vassil - Own work. Licensed under Public Domain via Commons).
Distribution: Brown-nosed coati is widely distributed in South America, occurs from Colombia,Venezuela to Uruguay, and north of Argentina (Grompper and Decker 1998). In spite of its wide distribution, the species is nowadays rare in the Caatinga, limited to the mountains ranges and little anthropized regions (Feijó and Langguth 2013).

Ethnozoological notes: As a game mammal it is of relatively small importance. The use of coatis as pets is recorded in some localities (Figure 41). When reared in captivity a coati will become entirely tame and a very entertaining addition to a household. Products derived from the species are used in popular medicine to treat diseases such as: sexual impotence, wounds, skin burns, snake bites, backache (Alves 2009; Alves et al. 2007).

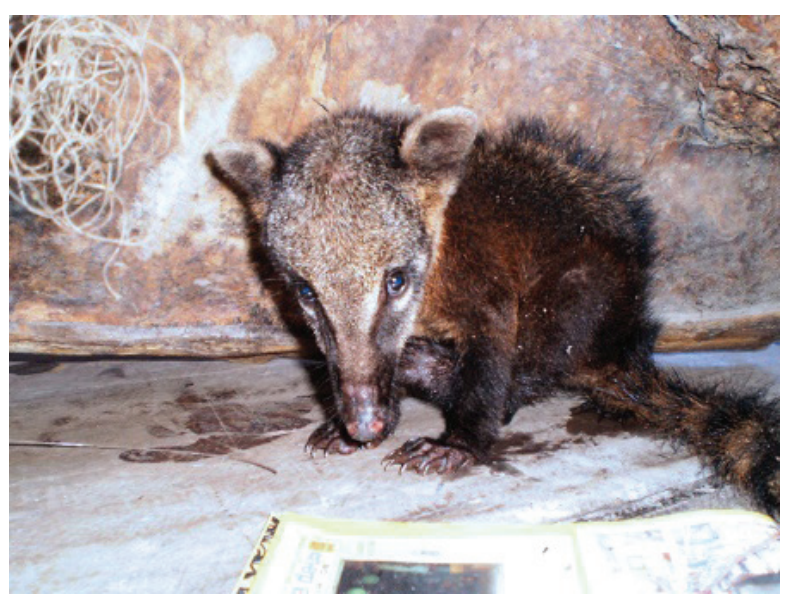

Figure 41. Nasua nasua (Linnaeus, 1766) kept as pet in a semiarid location in the state of Piaui (Photo: Raynner Rilke Duarte Barboza).

Procyon cancrivorus (G. Cuvier, 1798) (Figure 42) - Common names: Crab-eating raccoon, Guaxinim, Mão-pelada

Characteristics: Medium-sized species (headbody length: $597 \mathrm{~mm}$ ). The striking feature of this animal is the black stripe around the eyes, forming a mask. Above each eye there is a coronal white strip that highlights the mask. The forehead is grey, the base of the hairs is white or yellowish, and the distal region is black. The ears are relatively wide; they are grey at the base with a white strip on the top. The limbs, usually, are darker than the dorsum and in their distal half the fur is very short. The hands and feet have as striking features long and fine fingers with claws, on the feet the toes 
are shorter. The tail is also a characteristic of the species, and its fur is ringed with a dark brown or black bands alternated with grey ones. The tail's tip has thick and dark fur. The ventral region of the body, limbs, and head is paler colour than the dorsum. The skull has a short and long rostrum. The braincase is long and about half the length of the skull. The palate is long and extended until the last molar. The posterior edge of the palate has a small medial process. The dental formula is: $i 3 / 3$ c $1 / 1$ p $4 / 4$ m 2/2.

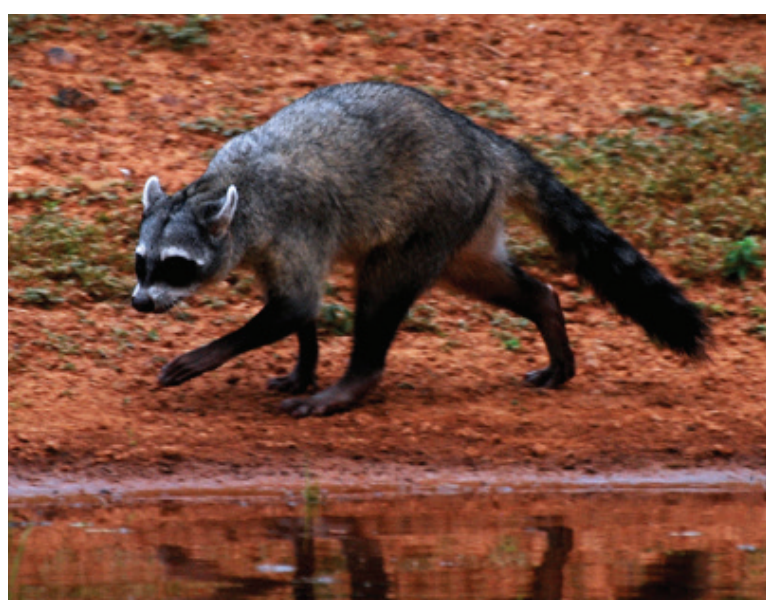

Figure 42. Procyon cancrivorus (G. Cuvier, 1798) (Photo: André Pessoa).

Distribution: $P$. cancrivorus is distributed from Costa Rica south to South America, Uruguay, and north eastern Argentina (Husson 1978). It is widely distributed in the Caatinga (Feijó and Langguth 2013).

Ethnozoological notes: The species can be considered a pest for some agricultural crops. Products of the species are used in popular medicine to treat: rheumatism, epilepsy, thrombosis, and snake bite (Alves 2009; Alves et al. 2007). The crab-eating raccoon can also be reared as pets (Figure 43).

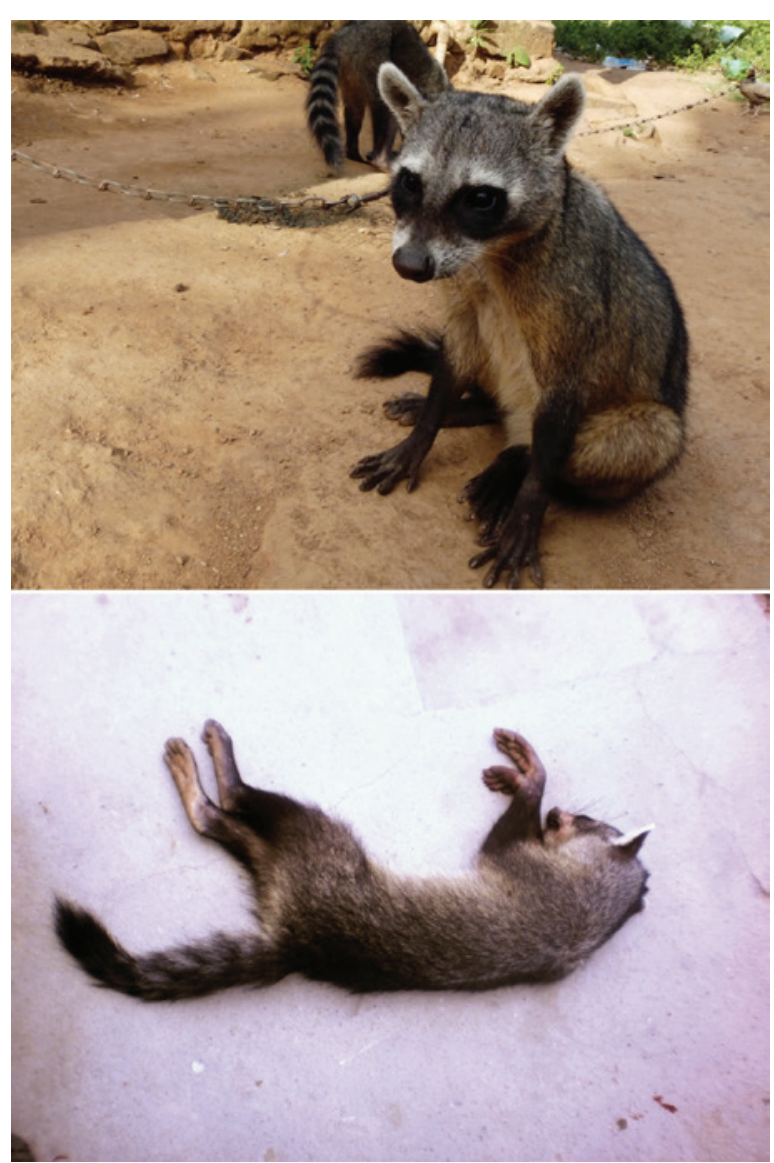

Figure 43. Procyon cancrivorus (G. Cuvier, 1798) kept as pets (above) and killed in retaliation for attacks on crops (Photos: Hugo Fernandes-Ferreira (Above) and Raynner Rilke Duarte Barboza (Below).

\section{ORDER PERISSODACTYLA}

Family Tapiridae Gray, 1821

Tapirus terrestris (Linnaeus, 1758) (Figure 44) Common names: Brazilian Tapir, Anta

This is the biggest terrestrial mammal in South America, its weight can be up to $300 \mathrm{~kg}$ (Ayala and Wallace 2010; Carter 1984). The dorsum is gray or light brown with a short pelage. The neck is short and robust. In the dorsum of the neck, there is a a dark crest extending to the shoulders. Above the eyes, between the ears there is an abrupt elevation of the head. The upper lip is well developed and joined to the nose forming a mobile proboscis that is curved downward. The lateral area of the inferior lip, chin, and throat is whitened. The ears are brown with a white edge. The tail is short. The anterior 
limbs have four fingers; three are well developed and the fifth is small. The posterior limbs have three fingers (Ayala and Wallace 2010).

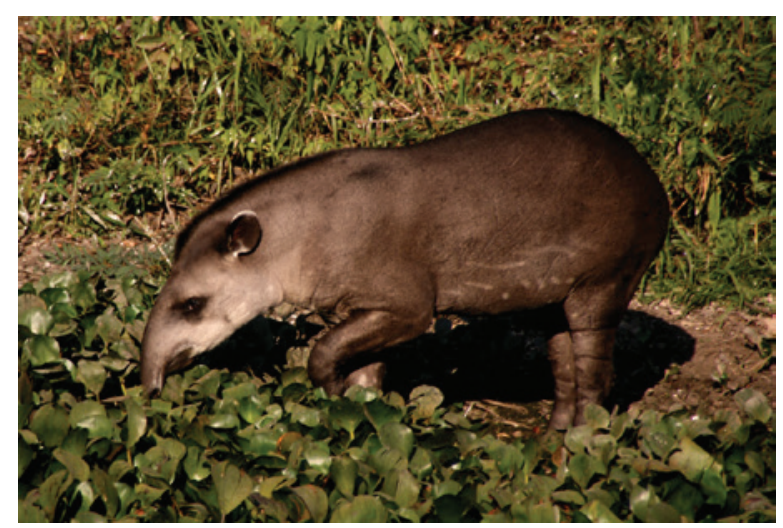

Figure 44. Tapirus terrestris (Linnaeus, 1758) (Photo: "Anta pantanal" by Marco Zanferrari - Flickr. Licensed under CC BY-SA 2.0 via Wikimedia Commons).

Distribution: The geographical distribution of this species includes the South American forests, eastern Andes, from Colombia and Venezuela to north of Argentina (Husson 1978). The presence of this species in the Caatinga is limited to historical records, and is probably extinct in this biome (Feijó and Langguth 2013).

Ethnozoological notes: Papavero et al. (2011) say that Pe. Breuer emphasised the record of a tapir killed by Indians of the Serra de Ibiapaba region, in Ceará, indicating the use as food associated to zootherapy. The document report consumption of the tapir's meat as healing venereal diseases, and inhalation of the manure as an apoplexy treatment.

\section{ORDER ARTIODACTYLA}

Family Tayassuidae Palmer, 1897

Pecari tajacu (Linnaeus, 1758) (Figure 45) Common names: Collared peccaries, Cateto

Characteristics: Medium-sized species (headbody length: $835 \mathrm{~mm}$ ) with a brown general colouration. The fur is hard and rough. Two white lines resemble a necklace that is extended from the throat at each side following obliquely along the shoulders to the dorsal region, although they do not meet each other. It has a short crest with a dark colouration which extends over the dorsum, being more distinct anteriorly. Odoriferous gland are found on the posterior medial region of the dorsum like those of the Tayassu pecari. The skull is robust and strong. The rostrum is long and narrow. The upper canines are straight, well developed, and their alveoli protrude on the lateral face of the rostrum. The orbits are relatively small. The braincase is small and occupies one fourth of the skull. The temporal crests join to form a high, but short sagittal crest on the posterior region of the braincase. The palate is long and narrow. In lateral view, the dorsum profile of the skull is straight. The pre-maxillary extend anteriorly beyond the nasals. The dental formula is: $i 2 / 3$ c 1/1 p 3/3 m 3/3.

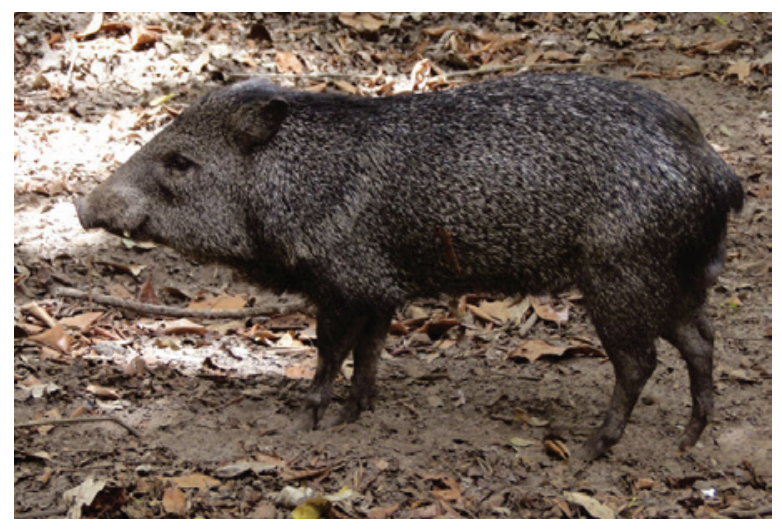

Figure 45. Pecari tajacu (Linnaeus, 1758) (Photo: Rômulo Romeu Nóbrega Alves).

Distribution: P. tajacu is the species with the biggest distribution within the Tayassuidae family. They occur in southern Texas and Arizona in the U.S.A., Mexico, Central America, South America, eastern of the Andes, and northern Argentina (Grubb and Groves 1993). P. tajacu populations in the Caatinga are extremely reduced. There are recent records in the municipality of São José do Sabugi, in Paraiba, and in the municipalities of Santa Quitéria and Aiuaba in Ceará, and in the city of Sento Sé, in Bahia (Feijó and Langguth 2013).

Ethnozoological notes: Collared peccaries are hunted for food and for use of its skin. Although it is considered a species resistant to environment changes (Desbiez et al. 2012), excessive hunting has reduced its populations and eliminated peccaries from most of their original distribution areas. Old hunting records demonstrate this 
situation, and it has been considered as an extinct species in several places.

It provides products for popular medicine, to treat diseases such as thrombosis, bronchitis and stroke (Alves et al. 2007). The species is also affected by conflict since they cause damage when invade tillage, provoking retaliations from cultivators.

Tayassu pecari (Link, 1795) (Figure 46) Common names: White-lipped peccaries, Queixada

Characteristics: Medium-sized species (headbody length: $1036 \mathrm{~mm}$ ). The most striking feature of this species is the whitened colouration of the chin, muzzle, and cheek. The general colour of the animal is dark or greyish brown, mixed with yellow or white. The fur is hard and rough. A short mane with long and dark fur extends throughout the whole dorsum length. The odoriferous gland is on the posterior medial line of dorsum, as is on $P$. tajacu. The ears are oval, and erect. The ventral surface of the body is less densely furry than the dorsum. The skull is similar to that of T. pecari but distinctly larger.

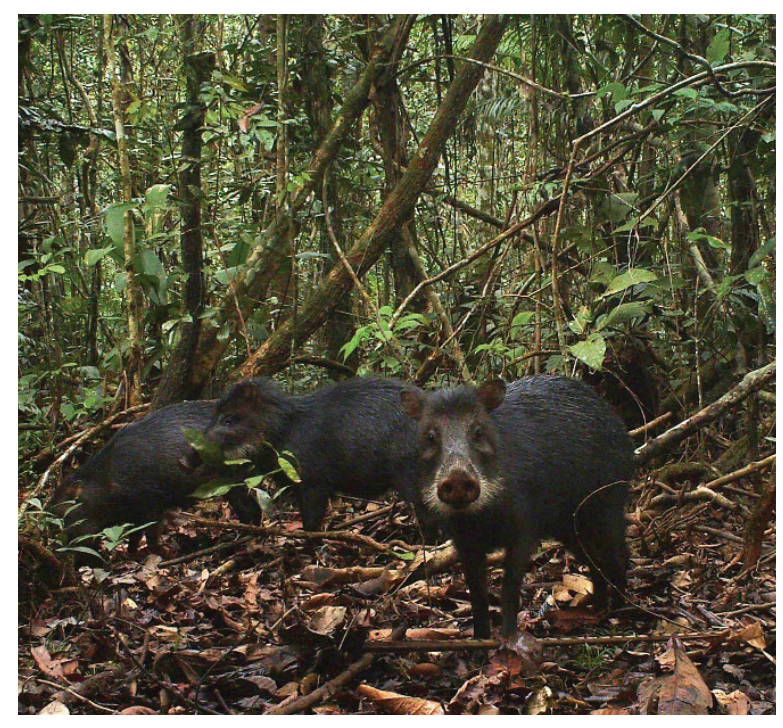

Figure 46. Tayassu pecari (Link, 1795) (Photo: Jaderson Souza).

Distribution: Tayassu pecari is found from Vera Cruz and Oaxaca, south of Mexico, along the eastern Andes, to the Entre Rios (Between Rivers) province, and the northeast of Argentina (Grubb and Groves 1993). Currently, the records of this species are scarce in the Caatinga.
Ethnozoological notes: As with $P$. tajacu, this is one of the most important game species of Brazil. The Caatinga is considered the extreme northeastern limit of distribution of the species. Nowadays, the white-lipped peccary population occupy well preserved areas, distant from cultivated areas. Sometimes, the use of crop plantations by peccaries results in conflict with rural producers, which often kill peccaries in retaliation for the economic losses caused to plantations (Jácomo et al. 2013, Mayer and Wetzel 1987).

Excessive hunting has caused extreme population fragmentation and elimination of white-lipped peccaries from large areas of its original distribution. The skin of this animal has also a market value. In popular medicine, products derived from the species are used to treat thrombosis and stroke (Alves et al. 2007).

\section{Family Cervidae Goldfuss, 1820}

Mazama gouazoubira (Fischer, 1814) (Figure 47) - Common names: Gray Brocket deer, Veado catingueiro

Characteristics: Medium-sized deer (headbody length: $860 \mathrm{~mm}$ ). The dorsal colour is brownish grey, darker on the medial region, and it becomes paler on the sides. The face has a dark colour in the middle region and is paler at the sides. The fur on the top of the head is most commonly directed backwards. Around the eyes there is a region of white or yellow fur. The external side of the ear pavilion is dark brown and the inner side has long white fur. Hairs of the dorsum and sides can have a sub-terminal yellow or orange band. The ventral part of the head and body is paler than the dorsum, it may be washed with white tones. The tail is short and it has the same colour of the dorsum, but on the tip it has a white tuft. Young animals have from six to eight horizontal stripes, formed by wide white spots, which are extended along the sides. The male develops simple and conical horns and its length depending on the animal's age. 


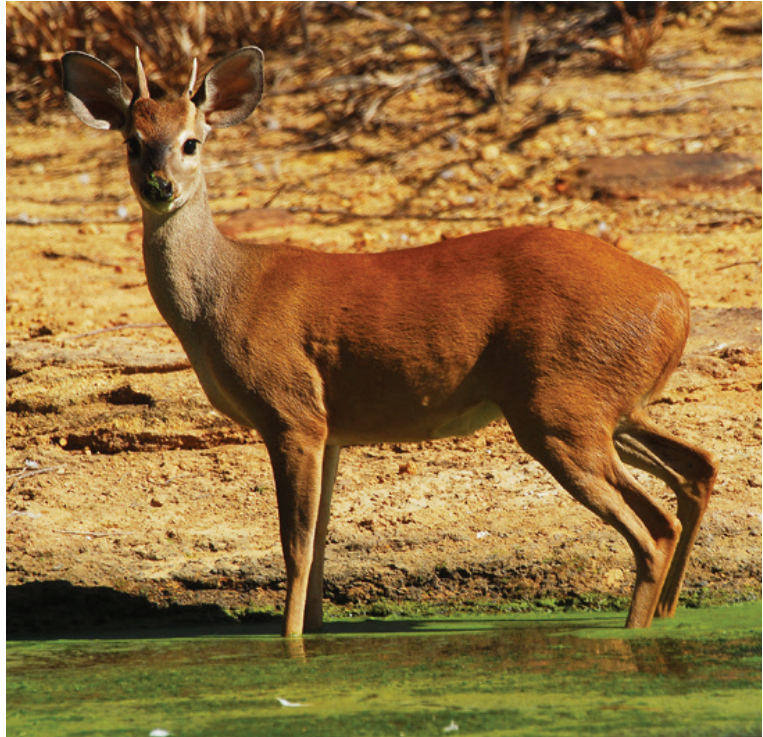

Figure 47. Mazama gouazoubira (Fischer, 1814) (Photo: André Pessoa).

\section{Distribution: Mazama gouazoubira is} distributed throughout Brazil, Bolivia, Paraguay, north of Argentina, and Uruguay (Black-Décima et al. 2010). It is widely distributed in Caatinga, mainlyin high regions, where access is more difficult (Feijó and Langguth 2013).

Ethnozoological notes: The Caatinga's deer is well adapted to the semiarid environment, being widely distributed in the region, despite the population diminishing due to hunting in several places in the biome (Figure 48). It is one of the most important game species of the region. Its meat is considered tender and delicious. It is now recognized that the population is in decline in various locations, in part due to hunting pressure, but also to habitat loss. Barboza (2013) noted that, in municipalities of semiarid region, these animals are considered difficult to chase, and are sometimes the target in competitions, in which the winner will receive higher status among his hunting friends. The animals can also be reared as pets, when captured while they are offspring. This species is also commonly used in popular medicine of the region.

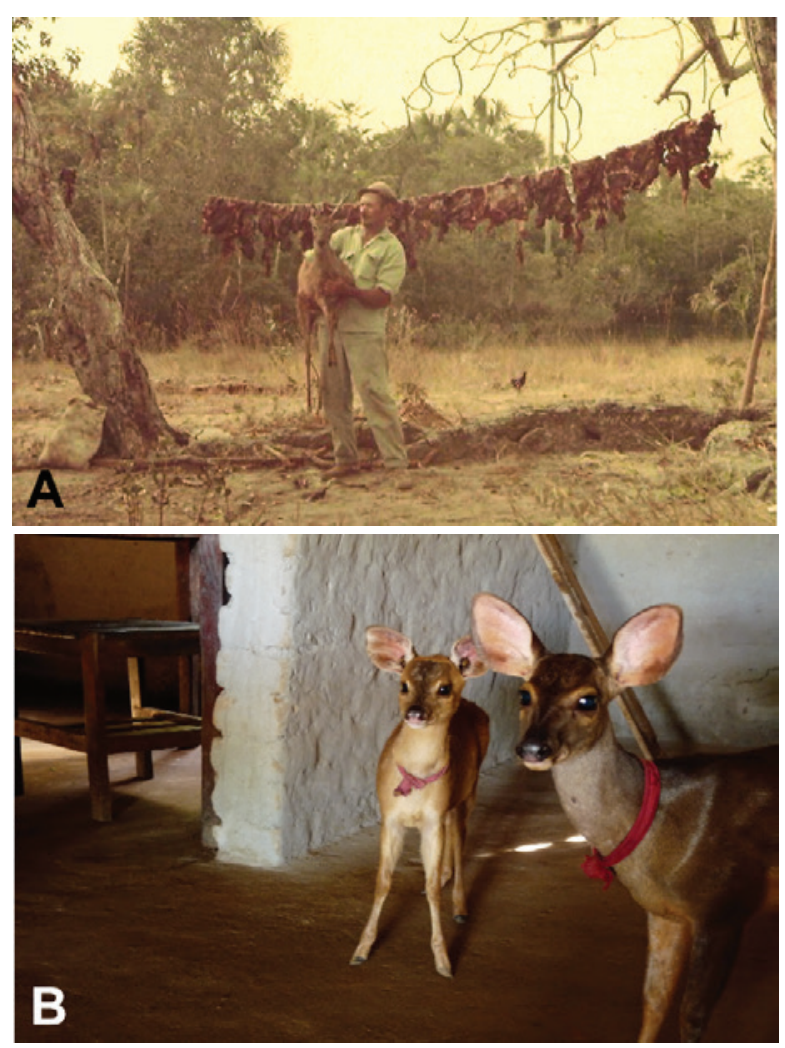

Figure 48. Hunter displaying a specimen of Mazama sp. recently killed in hunting expedition held in the 70 (A) and specimens kept as pets in an area of the Brazilian semiarid (B) (Personal photograph of semiarid hunter in courtesy to Raynner Rilke Duarte Barboza (A). Photo B: Hugo Fernandes-Ferreira).

Mazama americana (Erxleben, 1777) (Figure 49) - Common names: Red brocket deer, veado mateiro

Characteristics: The dorsum is a uniform reddened brown colour, being slightly darker on the medial region, and gradually paler on the lateral region. The anterior lip area is white. The ear is grey brown with a white stain on its external base and the internal fur is white. On the anterior, the abdomen becomes abruptly light grey brown. The tail is the same colour as the body's dorsum. The abdomen and tip of tail are white. The $M$. americana's skull is similar to that of the $M$. gouazoubira, but larger. 


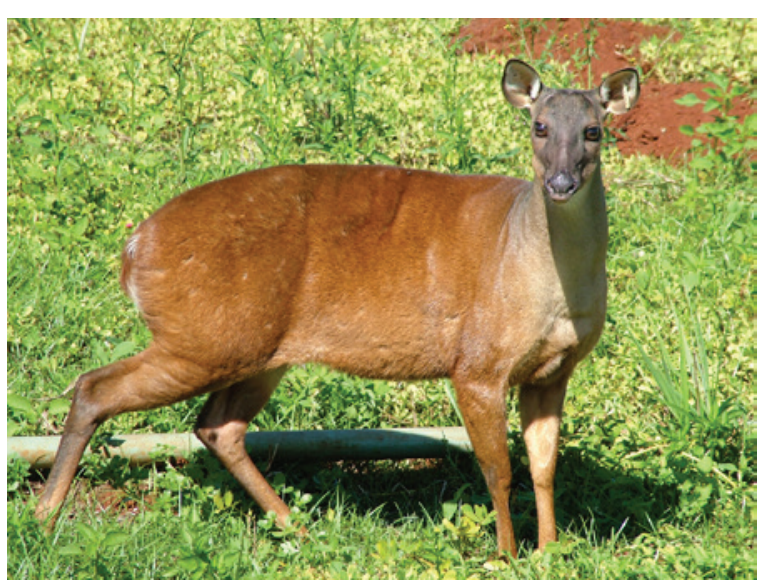

Figure 49. Mazama americana (Erxleben, 1777) (Photo: José Maurício Barbanti Duarte)

Distribution: $M$. americana has a wide distribution from south of Mexico to north of Argentina (Husson 1978). In Caatinga, its distribution is restricted to the west, in areas adjacent to the Cerrado (Varela et al. 2010).

Ethnozoological notes: The same interactions and uses described for Mazama gouazoubira apply to Mazama americana. It is also currently considereda rare animal. If a hunter wants to pursue this animal, they must to know its alimentary habits and must also be a keen observer, and have goodaim with a weapon.

\section{ORDER RODENTIA}

Family Caviidae Fischer, 1817

Hydrochoerus hydrochaeris (Linnaeus, 1766) (Figure 50) - Common names: Capybara, Capivara

Characteristics: The capybara is the biggest world rodent, with the length of the head and body varying from 1000 to $1300 \mathrm{~mm}$ (Eisenberg and Redford 1999). The dorsum colour is uniformly yellow. The dorsum fur of the basal region is brown grey and the rest is yellow. The head profile is in a rectangle form, and the muzzle is flattened frontally. The colour of the head is similar to the dorsum, but the muzzle is black with short fur. Around the eyes there is a white fur ring; in some individuals this ring is less perceptible. The ears are conspicuous, black, and with a vertical posterior edge. The fur on the abdomen is a little shorter and has a paler colouration than the dorsum. The hand has four fingers and the feet have three toes. The fingers and toes are connected by inter-digit membranes, extended to the nails. The tail is short and completely covered by the croup fur. The skull is robust and flattened dorsally, with a long and wide rostrum. The nasal bones has a rectangle form and is wide. The zygomatic arch is robust, with a wide jugal, and is part of the external mandibular joint. The paraoccipital process is very developed. The dentition is extremely lophodont. The mandible has an extremely developed masseteric crest.

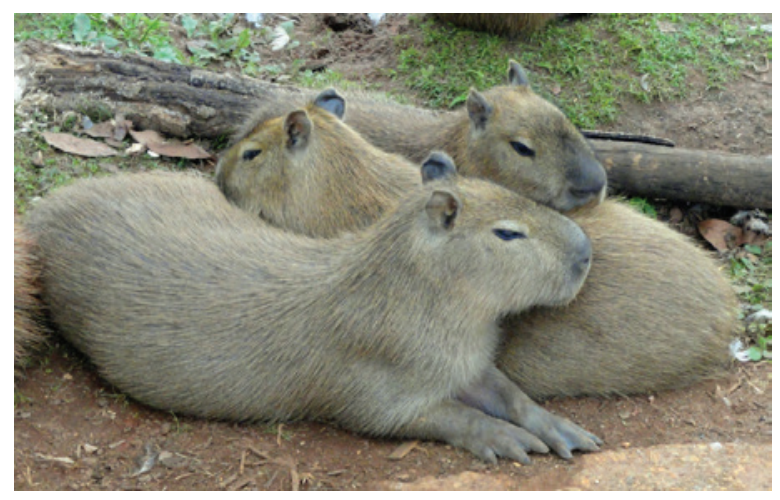

Figure 50. Hydrochoerus hydrochaeris (Linnaeus, 1766). Photo: "Hydrochoerus hydrochaeris - Jardim Zoológico de Brasília - DSC09912" by Daderot - Daderot. Licensed under CCO via Wikimedia Commons.

Distribution: It is distributed from Panama to Paraguay, and Uruguay (Husson 1978). Mones and Ojasti (1986) question the existence of this species in the semi-arid region of the Brazilian northeast. According to Feijó and Langguth (2013) it is probable that the capybara existed near the perennial riverside on the semi-arid. The shortage of records may be a consequence of the strong anthropization of the areas near the water streams of the region.

Ethnozoological notes: This animal is used as a protein and medicine source. It is derived products are used to treat diseases such as: thrombosis, conjunctivitis, venereal disease, rheumatism, earache, weak bones, liver pain, bronchitis, asthma, wounds, erysipelas, and cough (Alves et al. 2007). It is also a target in conflict with inhabitants of the region because they prey on agricultural cultivations, which motivates their slaughter. 
Galea spixii (Wagler, 1831) (Figure 51) Common names: Spix's Yellow-toothed Cavy, Preá

Characteristics: This is species is slightly bigger than the Cavia aperea (head-body length: $240 \mathrm{~mm}$ ). The dorsal fur is less shiny than that of the Cavia and the colour varies from grey to brown mixed with orange or yellow. The lateral region of the body has a paler tone than the dorsum. The periocular region is limited by short white fur. A tuft of light fur is usually present on the rear base of the ears. The abdomen varies from white and cream, except in the gular region which is the same colour as the dorsum. The mental region is nude and of a dark colour. The furry foot is the same colour as the lateral body. The skull has a wide and short rostrum. The sagittal crest is short and the inter-parietal is distinct. The incisive foramen is short and narrowed, it is not expanded on the posterior part. The superior incisive is orange on the anterior. The angular process of the mandible is developed (Oliveira and Langguth 2004). G. spixii is differentiated of $C$. aperea by an arc with a paler colour around the eyes, and the yellow color of the incisive.

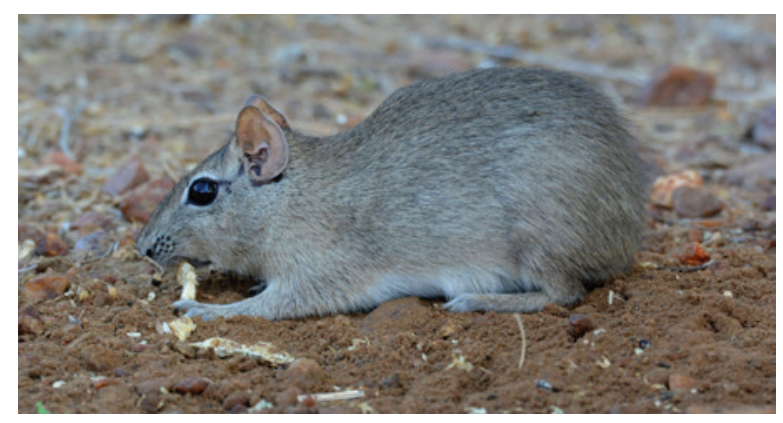

Figure 51. Galea spixii (Wagler, 1831) (Photo: John Philip Medcraft).

Distribution: It is present in Bolivia, Brazil, throughout Pará, Bahia, Minas Gerais, Goiás, Mato Grosso, and in the Federal District (Oliveiraet al. 2003). As the anterior species, it is widely distributed in Caatinga (Feijó and Langguth 2013).

Ethnozoological notes: The Spix's Yellowtoothed Cavy is one of the most hunted species in the semiarid. Even though it is a small animal, it is commonly hunted in great number, with guns and traps on the hidden crave ones (Alves et al. 2012a; 2009a). They are also used in popular medicine to treat inflammations (Marques 1995).
Kerodon rupestris (Wied, 1820) (Figure 52) Common names: Rock Cavy, Mocó

Characteristics: Kerodon rupestris is bigger than the Cavia and Galea (head-body length: 315 $\mathrm{mm})$. The dorsum is grey, mixed with yellow, black, red, and white. The medial dorsum region is darker than the lateral parts. The abdomen is white or grey. It has no tail. The cheek is light grey and the periocular region has a well-delimited white ring. The croup and the posterior limbs regions have a rusty tone. The sub-nasal whiskers are long and extend beyond the tip of the ear. The skull has a long and narrowed rostrum. The interparietal region is well developed. The incisive foramen is very reduced and narrowed (Oliveira and Langguth 2004).

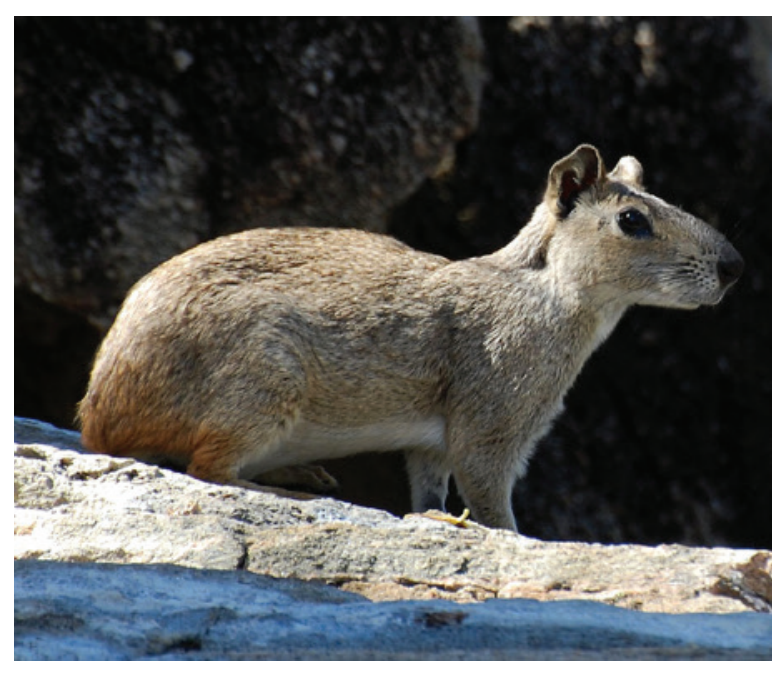

Figure 52. Kerodon rupestris (Wied, 1820) (Photo: John Philip Medcraft).

Distribution: It is present in states of Piauí, Ceará, up to the north of Minas Gerais, in Brazil (Bonvicino et al. 2008).

Ethnozoological notes: The rock cavy's meat is highly appreciated and consumed on the Brazilian semiarid region (Alves et al. 2012a; Alves et al. 2009a; Barboza 2013). It is salty and dried exposed to the sun; it is commercialised in markets exposed in blankets with five up to ten individuals. The untreated skin can also be used on the craft work confection (Vieira 2009). Part of its stomach (locally called "the rock cavy's curd) is used in the home-made craftwork cheese production, which is 
locally called "curd cheese" (Figure 53) (Alves et al. 2012a).
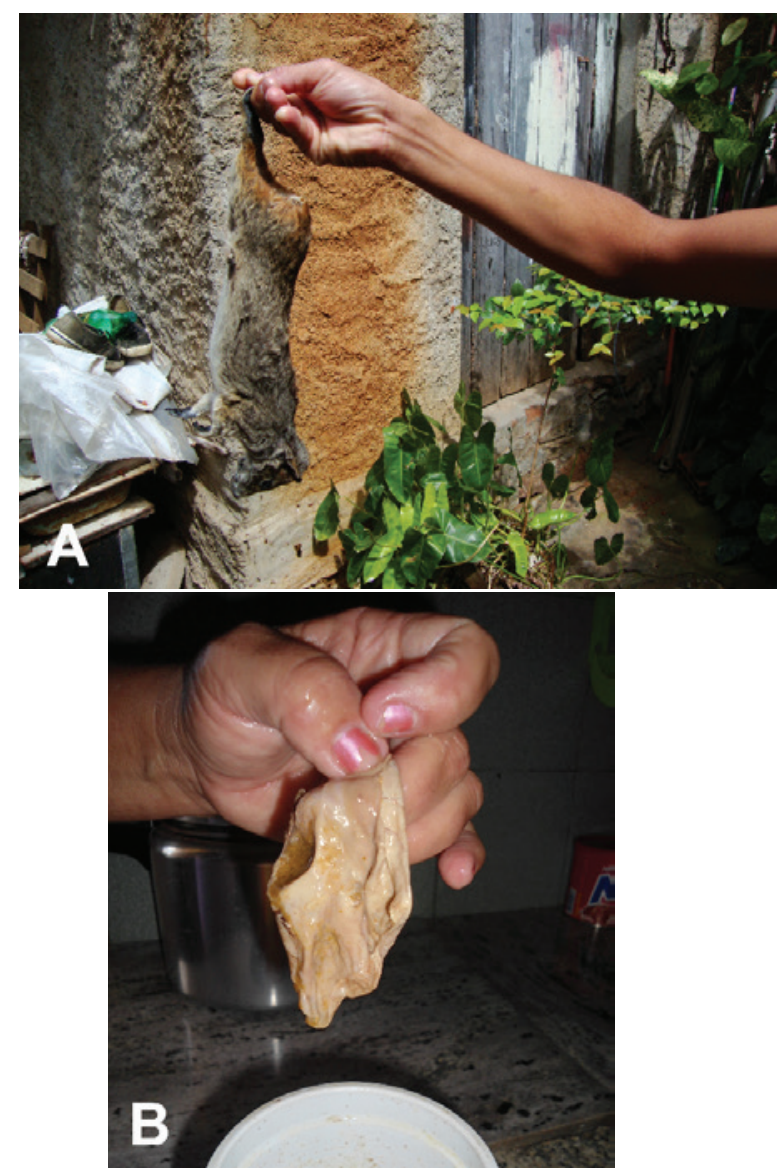

Figure 53. Kerodon rupestris (Wied, 1820) shot in hunting $(A)$ and the animal stomach (locally called "coalho") (B), used in artisanal preparation of curd cheese. Photos: Raynner Rilke Duarte Barboza $(A)$ and Maria Betânia Ribeiro Gonçalves (B).

\section{Family Echimyidae Gray, 1825}

Thrichomys laurentius Thomas, 1904 - (Figure 54) - Common names: Common Punare, Punaré

Characteristics: A small-sized species (headbody length: $197 \mathrm{~mm}$ ). The tail is a little smaller than the head. The ear is rounded and very developed, with a notch on the extreme edge. The mistacious whiskers are long and can surpass beyond the ear. There are two white semi-lunar stains: one is under and the other is above the eyes. The general dorsum colouration is brown-grey, and the abdomen is totally white; sometimes cream in the thorax region, with a distinct separation between the two areas. The tail is furry and grey. The foot's dorsum is grey. The skull is long, with a short rostrum. The superior incisive are opistodontes and the anterior portion is orange.

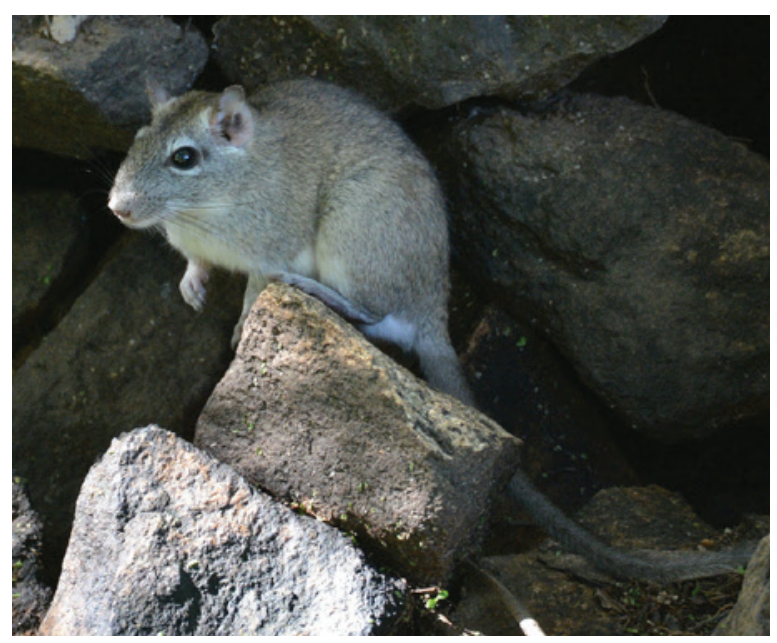

Figure 54. Thrichomys laurentius Thomas, 1904 (Photo: John Philip Medcraft).

Distribution: This species is widespread in Caatinga (Oliveira and Langguth 2004).

Ethnozoological notes: The species is much appreciated by the human population in Caatinga, who consume it as a protein source. The species can be hunted with a shotgun or with rustic traps.

Family Cuniculidae Miller and Gidley, 1918

Cuniculus paca (Linnaeus, 1766) (Figure 55) Common names: Spotted Paca, Paca

Characteristics: Medium-sized rodent (headbody length: $704 \mathrm{~mm}$ ). The dorsum is uniformly dark brown or reddened brown, with a standards dotted character and white lines on the lateral body. The dots are placed in lines across the lateral area of the body, the medial ones extend from the neck to the rump, and they can also form a single line. The lateral lines are only visible on the anterior extremities and body's posterior. The body fur is short and shiny. The muzzle has long whiskers: the superior ones are black and the inferior ones are white. Similar fur is also placed above and under the eyes, the superior is black and the inferior white. The ears have a yellow or whitened tuft on the inner side. The throat, cheek, and abdomen have a 
uniform colouration which is white or cream. There is a distinct separation between the dark dorsum and the white abdomen. The tail is relatively small. The hands and feet have five fingers. The skull is wide and triangular with a short and wide rostrum. The nasals bones are short, wide, and triangular. The conspicuous lacrimal projection is present on the superior orbital edge. The encephalic skull is short and wide, occupying around one third of the skull's length. The temporal crests are gathered in a low sagittal crest in the middle of the encephalic skull. The frontal region and the face of the external zygomatic arch are wrinkled. The zygomatic arch is robust, forming the maxillary, and the jugal: a rugosa plaque which ventrally covers a large part of the mandible. The para-occipital is well developed, surpassing the auditory bulla. The mandible has a strongly curved structure, where the anterior half is projected ventrally to lodge in the big incisive alveolar.

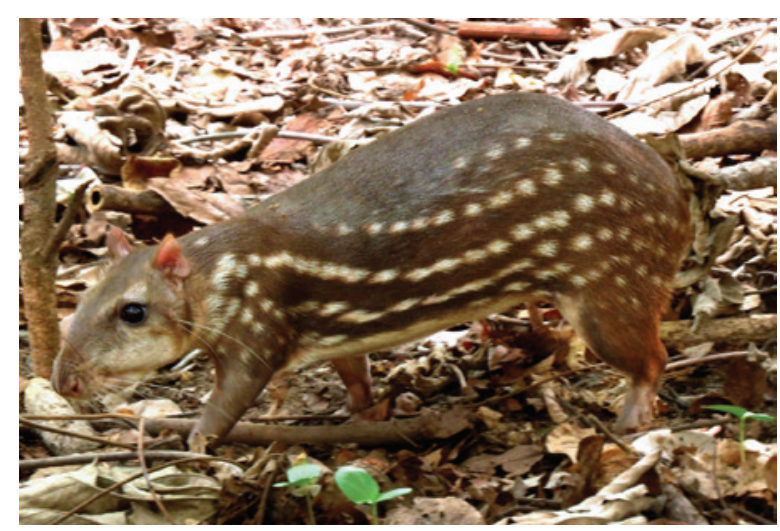

Figure 55. Cuniculus paca (Linnaeus, 1766) (Photo: Wanieulli Pascoal Lopes Nascimento).

Distribution: C. paca is present in the central part of Mexico, north of Argentina, Central America, the Antilles Islands, Cuba, Colombia, Venezuela, Guianas, Ecuador, Peru, Bolivia, Paraguay e Argentina (Husson 1978). Despite the strong pressure which this species suffers, a small population is still dispersed throughout Caatinga, on the Floresta Chapada (Stoned Forest), hills, and sawyers mainly in proximity to water streams (Feijó and Langguth 2013).

Ethnozoological notes: This animal is hunted mainly for its meat (Figure 56), which is considered very delicious by the local inhabitants. The species pressure is allied to deforestation which is provoked by the population decline of the species in several localities. This animal is also used in popular medicine.

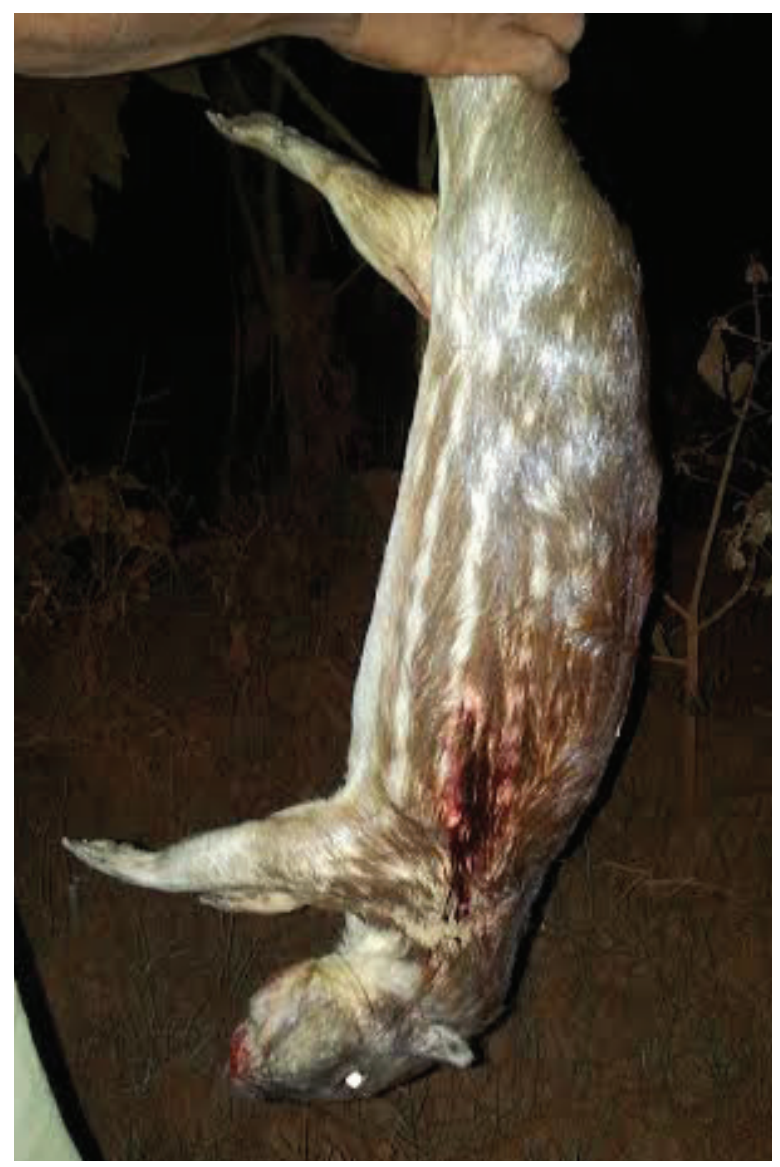

Figure 56. Specimen of Cuniculus paca (Linnaeus, 1766) killed during hunt activity (Photo: Marco Antonio de Freitas).

Family Dasyproctidae Bonaparte, 1838

Dasyprocta prymnolopha Wagler, 1831 (Figure 57) - Common names: Black-rumped Agouti, Cutia-da-garupa-preta

Characteristic: Medium-sized rodent (head-body length: $488 \mathrm{~mm}$ ). The head's dorsum is orange and brown dotted. Fur on the head increases gradually in size from the nostrils to the neck. Long black fur forms a hood on the inter-auricular region, extended on the neck's dorsum. The chin and the head intermandibular region are whitened. The neck's ventral region is yellow with the fur base varying from a dark brown tone to a light brown one. The ears have, usually, an orange colouration. The body's dorsum is dark brown with orange dots. The dorsum's medial 
region is darker and tends to become more orange as they bend to the lateral sides. The rump has very long black fur, sometimes darker on the tail. The abdomen is yellow, sometimes with a slim white line. The skull has a long and wide rostrum, which is slightly constricted in the middle. The supraoccipital crest is pro-eminent and the sagittal crest is low and situated on the posterior region of the skull. The para-occipital process is well developed and triangular. The incisive are an anterior orange colour. The pre-maxillary is distinctly projected to the front, further than the incisive, being aligned to the nasal extremity.

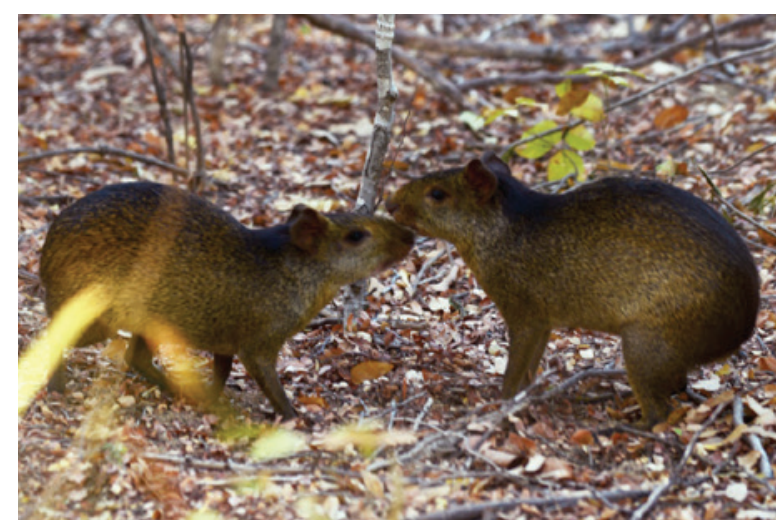

Figure 57. Dasyprocta prymnolopha Wagler, 1831 (Photo: André Pessoa).

Distribution: This species is present from Pará to the east side of the Tocantins river, Maranhão, Rio Grande do Norte, Ceará, Pernambuco, Alamosa, Goiás and north eastern Minas Gerais (lack-Ximenes 1999). D. prymnolopha is recorded in high altitude swamp areas or arboreal vegetation (Feijó and Langguth 2013).

Ethnozoological notes: This is also one of the most important game species in the semiarid region, representing an important protein source. Hunting is associated with loss of its habitat, which is pressing the natural population of the species. As well as its use as a food, products derived from the species are used in popular medicine.

\section{Family Erethizontidae Bonaparte, 1845}

Coendou baturitensis Feijó and Langguth, 2013 (Figure 58) Common names: Baturite porcupine, Porco-espinho, Ouriço-cacheiro
Characteristics: This medium-sized rodent (head-body length: $500 \mathrm{~mm}$ ) is densely covered by quills of different length and thickness, they cover the animal's body from the base of the muzzle base up to the tail's edge. The quills on the anterior part of the head are short and fine, and become longer on the dorsum of the body. The quills are tricoloured: the base and the tip have a dirty white tone, and the middle is light brown. On the dorsum region of the body, the basal and distal bands are small. The ears are short, and covered by quills. The area around the eyes is a narrow area without quills. The quills on the ventral surface of the body are thinner, shorter, and more flexible than those on the dorsum. The hands have four fingers and the feet four toes with very developed claws. The skull is characterized by the pneumatisation of the whole nasal bone as well as the frontal anterior region. In a lateral view, the rostrum is higher than it is long. The nasal bone anterior extremity is distinctly behind the incisive ones.

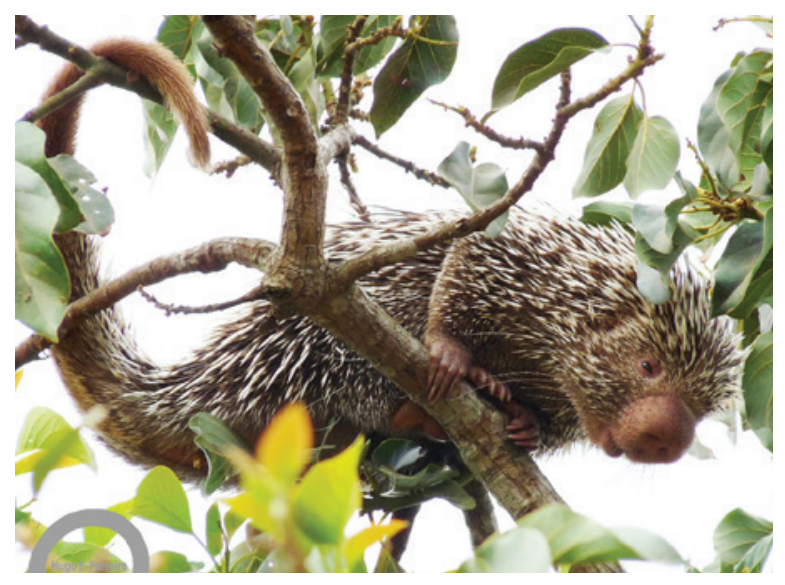

Figure 58. Coendou baturitensis Feijó and Langguth, 2013 (Photo: Hugo Fernandes-Ferreira).

Distribution: Until now the species has been restricted to the Serra de Baturité, in Ceará, Northeast of Brazil (Feijó and Langguth 2013).

Ethnozoological notes: On the Serra de Baturité, Coendou baturitensis hunting occcurs mainly during the full moon, when hunters could easier find the animal. In some locations there is a food taboo associated with the animal. According to local inhabitants, a person who kills a $C$. baturitensis will suffer bad luck for forty years (Fernandes-Ferreira 2011). It is important to emphasize that one of these locations is the 
Barreiros community (in Aruba, Ceará), which is the type locality of the species.

Coendou prehensilis (Linnaeus, 1758) (Figure 59) - Common names: Brazilian porcupine, Porcoespinho, Ouriço-cacheiro

Characteristics: Medium-sized rodent (headbody length: $396 \mathrm{~mm}$ ). C. prehensilis resembles $C$. baturitensis, being differentiated by the standard quill colouration and by its general colour, which is paler. On the $C$. prehensilis's the dorsum region the quills have a yellow base, and narrow dark brown or black band, and the terminal band is white and wide. On the $C$. baturitensis's dorsum the base of the quill is short and has a dirty white tone, the intermediary band is wide and brown, and the terminal band also has a dirty white tone and is short. The lateral region of the body in the Baturitensis porcupine has smaller quills than the dorsum, whereas there is no distinction between the lateral and the body's dorsum quills in C. prehensilis. C. baturitensis have uniformly convex nasals bones, while in the $C$. prehensilis'the dorsal profile has an abrupt elevation on the posterior half of nasal bones. In the frontal edge for $C$. baturitensis, the area between the preorbital and post-orbital processes is straight, while in the $C$. prehensilis the edge is concave.

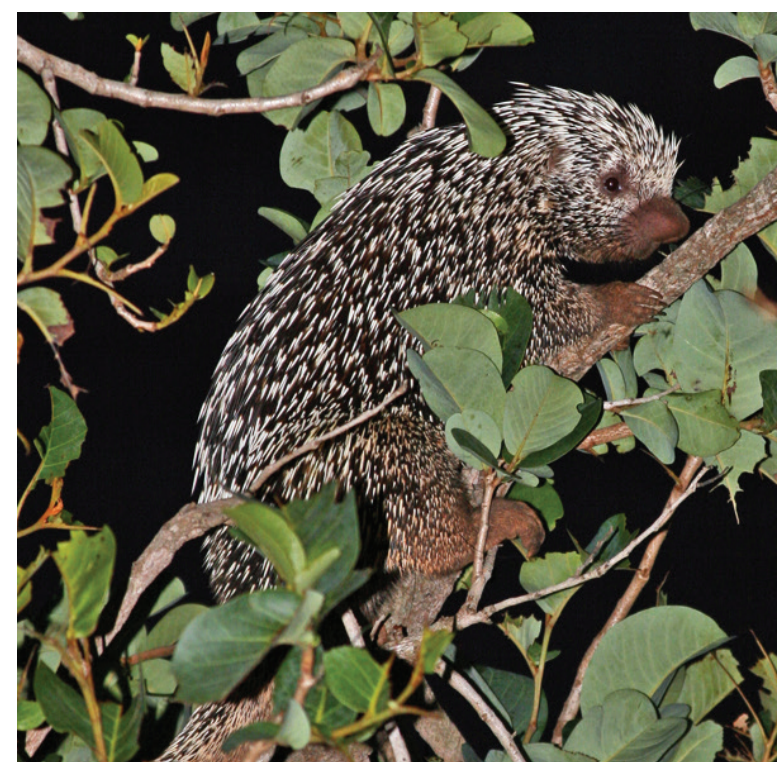

Figure 59. Coendou prehensilis (Linnaeus, 1758). Photo: "Coendou prehensilis JJK'1" by Jacek Kisielewski. Licensed under CC BY-SA 3.0 via Wikimedia Commons
Distribution: This species is present from the north of Colombia, north east of Argentina, and Paraguay, including Venezuela, Guianas, Suriname, Ecuador, Peru, and all over Brazil, except in the south region (eastern Andes) (Bonvicino et al. 2008; Voss 2011).

Ethnozoological notes: The species is hunted as a meat source. Also, the animal is frequently killed, because the spines hurt pedigree dogs, during fights. The spines of the porcupine are used in the popular medicine of the region. The popularity of this use means that this product is well commercialised in public markets all over Brazil (Alves et al. 2009b; Alves and Rosa 2010; Ferreira et al. 2012, 2013)

\section{DISCUSSION}

Our results show that a high number of the Caatinga mammals have been interacting with the local human population, in a scenario that has persisted from ancient times until recent days (Alves et al. 2009a, 2012a; Barbosa et al. 2011; Barboza 2013; Melo et al. 2014b; Mendonça et al. 2011; Mourão et al. 2006; Pereira and Schiavetti 2010). Local inhabitants have established interactions with at least 41 mammal species, in which they are used for multiple purposes, mainly as a protein source. Mammals represent the preferential taxonomic group when it comes to game species, reflecting a similar pattern to that of several neo-tropical biomes (Mena et al. 2000; Mesquita and Barreto 2015; Monroy-Vilchis et al. 2008; Ojasti 2000; Redford and Robinson 1991; Robinson and Bodmer 1999; Silvius et al. 2004; van Vliet et al. 2014, 2015).

It is important to point out the game preference for mammal fauna in the Caatinga Domain, although the bird-fauna has also played an important role as a game resource, which is surely influenced by the remarkable richness of the bird species in Caatinga biome, where there are 511 bird's species (Albuquerque et al. 2012; Alves et al. 2010a; Silva et al. 2003).There has been a recognized population decline, or local extinction, of several medium and large-sized mammal species in the region, those which, historically, used to constitute the main prey 
of local hunters, and which are nowadays no longer available in most of the biome. This reality has been registered in several localities of the region, where the hunters point out that the game animals have been suffering a population decline. The animals which have suffered include: deer (Mazama americana and M. gouazoubira), peccary (Tayassu pecari and Pecari tajacu), puma (Puma concolor), tapir (Tapirus terrestris), the giant anteater (Myrmecophaga tridactyla), three-banded armadillo (Tolypeutes tricinctus), among others (Alves et al. 2012a, 2009a; Barboza 2013). Such a situation is described by Barboza (2013), who made a comprehensive study of the use of wild mammal fauna in the Brazilian Northeast semi-arid, and noticed that the local hunters recognize the disappearance of medium and large mammals in various locations; this is only recorded through personal accounts and old pictures. This reinforces the idea that factors such as capture and excessive slaughter, coupled with habitat loss, have caused large populations to diminish, and apparent local extinction of many animals in several areas of the region.

This situation allows us infer that the hunting of medium and large mammals in Caatinga is unsustainable, particularly when the high degradation of this biome and the high pressure on the remaining population of these animals. Several researchers have demonstrated that bigger mammals suffer even bigger hunting pressure, require a greater area, and have low abundance and population growth rate, which makes them extremely sensitive to the fragmentation and alteration of their habitats (Henle et al. 2004; Noss et al. 1996; Terborgh and Winter 1980). This number of factors worsens the population decline of bigger mammals in different biomes, interfering directly with their diversity and resources (Chiarello 1999; Lopes and Ferrari 2000; Michalski and Peres 2007, 2001). In Caatinga this situation seems even worse, when the degree of degradation in this biome is considered. It is among the least-known and least-protected Brazilian ecosystems. Only one percent of its original area is under legal protection, and most of the protected areas are and understaffed - it is common to have a single park ranger responsible for areas of over 100,000 ha (Melo et al. 2014a; Oliveira et al. 2012). In this scenario, medium-sized herbivores and carnivores are the main mammal families affected by their exploitation as a protein source (and for other purposes) or because they are the constant target of conflict with inhabitants of this region.

It is important to emphasize the recognized decline of medium and large mammals is worrying not only because it affects their population directly, but also because it compromises the important ecological functions that they have. Large herbivores are important seed and seedling predators, and seed dispersers, and as some studies point out, the local extinction of these species affects the composition, diversity, and regeneration of the tropical forest (Carrillo et al. 2000; DeMattia et al. 2004; Dirzo and Miranda 1990; Terborgh 1988). In the same way, large predators play an important role in the structural regulation of the community of these forests, through the topdown control of the mammal herbivore population and the general medium-sized mammals, called meso-predators (Fonseca and Robinson 1990; Terborgh et al. 2001).

The game preference for mammals is a trend that has been recorded in different locations of the Brazilian semi-arid region (Alves et al. 2012a, 2009a) and of the world (Bodmer et al. 1997; Fusari and Carpaneto 2006; Ojasti 1984; Peres and Nascimento 2006). This choice is clearly influenced by the larger size of the mammals (compared to other terrestrial vertebrates), which offers a bigger biomass for the hunters (Alvard et al. 1997; Alves et al. 2009a; Mena et al. 2000; Peres and Nascimento 2006). In Caatinga, with the mammalian population decline, game pressure is migrating to small mammals and to bird species; recently this group has been taking a game importance similar to that of mammals. Even though there are fewer mammals than birds in Caatinga, mammals have a bigger biomass on average, meaning that despite the population decline of some mammal species, the game importance of these two groups is equal. This situation is well illustrated in research by Mendonça et al. (2016), which considered the annual consumption of wild animals by hunters' families in a certain location of the semi-arid in Paraiba (Northeast Brazil), and they noticed a higher consumption of birds than mammals, but an equal biomass con- 
sumed for both. This suggests that with the greater mammalian population decline there is now more pressure on the other species of smaller size and on other vertebrate groups, which were once less exploited. The herpetofauna has representatives among the wild vertebrate of game importance in Caatinga, generally the lizards Salvator merianae and Iguana iguana (Alves et al. 2012b), even though the number hunted is much smaller when compared to the bird-fauna and mammals-fauna game of the region. Such a situation is different to the one recorded in Amazonia, where reptile groups such as the Chelonians (turtles) have played an important role in the riverside dwellers' diet (Alves and Santana 2008; Alves et al. 2012d).

We could notice ethnozoological connections among the people and the mammals-fauna living in the same area on the Caatinga Domain have been provoking evident consequences to some local mammals, of which we could highlight the following: a) medium and large-sized species were intensely hunted and are locally extinct in the most of the biome, mainly big deer and big carnivores, in addition to the species like the giant anteater and armadillos as Tolypeutes tricinctus, Priodontes maximus, and Cabassous tatouay; b) Medium-sized species are still being hunted in the most of the biome, and with the recent decline of big-sized species, they have become the main game mammals of the region, the most affected are the six-banded armadillo (Euphractus sexcinctus), nine-banded armadillo, the skunk (Conepatus amazonicus), and the anteater (Tamandua tetradactyla); c) small-sized species with fast reproduction are still being hunted in a high number of specimens, in order to compensate for their small biomass, the hunting of the Brazilian guinea pig (Galea spixii) and rock-cavies (Kerodon rupestris) being highlighted; d) carnivore species are usually slaughtered because they are the targets in a relationship of conflict with people, the most affected are the jaguars and wild cats (e.g. Leopardus pardalis, L. tigrinus, L. wiedii, Puma concolor, Puma yagouaroundi and, Panthera onca).

For most of the species, their main use is as meat for food. Even when hunting is just for entertainment or due to a relationship of conflict between people and animals, the meat of the slaughtered species is used as a protein source. There is also a series of other products that can be used, which includes ornamental, medicine, and religious-magic usages. Such notice evidenciates a hunters' strategy who aims to optimize the usage of the obtained resource, therefore, it is not a surprise that practically all the game species compiled in this paper have more than one purpose. Most of the hunted species are consumed as food, and naturally, the inedible parts generate "leftovers" (other products) that can be used for other purposes. This situation is well-illustrated when we analyse the zootherapeutical use of the fauna, which, according to Moura and Marques (2008), is based mainly on the use of leftover/secondary products derived from the fauna, which seems to be one of the most striking features on the Brazilian popular zootherapy. These authors also emphasize the fact that from the ecological theory point of view, the use of these "leftovers" could be justified as an attempt to leverage the resources obtained from these ecosystems - horns, feather, scales, etc. - which are inappropriate for alimentary consumption due to the mechanical difficulty of ingesting these parts. Our data corroborates this, and demonstrates that the use of these leftovers is not only for popular medicine, but also extends to other usage, such as for ornaments and religious magic.

The diversity of mammals used for food is not directly related to subsistence purposes, sometimes being the result of the entertainment that it gives the hunters in the practice of those game activities. Furthermore, there is a clandestine commerce of products derived from these animals for several purposes, including use of the living animal as a pet. Some studies made in the free markets and fairs of cities of the semiarid region record that several products of mammal-fauna are commercialised for use in popular medicine (Alves et al. 2008, 2009b, 2010b; Alves and Rosa 2010; Ferreira et al. 2012; Ferreira et al. 2009b, 2013) and religious magic (Alves et al. 2012c). The use of the wild mammals as meat and their sale as pets also occurs clandestinely in the region (Barboza 2013; Barboza et al. 2016). It is important to emphasize that the clandestine commerce in several products derived from the wild mammal-fauna is a factor that increases the impact on these animals. The animals that are often commercialised as pets are 
the primates, sloths, and some carnivores, or those that offer products such as meat, skin, bones, fat, and other parts, that are sold for use in popular medicine, ornamentation, or religious magic.

Other striking feature that determines the hunting in Caatinga are the conflicts between local inhabitants and some wild species. In the case of mammal-fauna, such conflicts are due to the following reasons: a) because those wild mammals prey on livestock, then causing harm to people; b) the danger that these animals represent in the direct possibility of attacking people, these conflicts involve bigger carnivores; c) the risk that these mammals represent to hounds, considered very valuable animals, which are fundamental for the hunters in their game practices; this group mainly includes the anteaters and carnivores, and d) mammals that cause damage to cultivation, mainly rodents and some carnivores such as foxes and raccoons. On the whole, our results confirm that carnivores are the main mammals involved in conflict in the Brazilian semiarid area, which is not a surprise, considering that most large carnivore species are experiencing global decline, driven almost entirely by human activities and/or conflicts with humans (Inskip and Zimmermann 2009; Michalski et al. 2006).

In Caatinga, these relationships of conflict are a factor that has historically stimulated the hunt of several carnivore species, which are not tolerated because of the damage they cause to livestock. This is common all over the biome and intensified throughout Caatinga's occupation. Similar findings were reported from Mato Grosso State, Brazil, where Trinca and Ferrari (2006) observed that some local hunters were in favour of the extermination of any predators with the potential to attack humans or their domestic animals, even if these predators lived in their natural forest environment far from human settlements. Wildlife-human conflict is a widespread conservation issue of increasing concern to conservationists (Conover 2002; Graham et al. 2005; Inskip and Zimmermann 2009; Marshall et al. 2007; Treves et al. 2006; Vázquez and Gaston 2006). In Caatinga, it has been affecting not only mammal population, but also birds and reptiles, when they are considered dangerous, or because they cause damage to people (Alves et al. 2009a, 2012b; Fernandes-Ferreira et al. 2012, 2013; Mendonça et al. 2011). Among the recorded mammals, $13(31.7 \%)$ are listed in some threatened category (Critically endangered, Endangered or Vulnerable). Hunting is one of the main factors contributing to this situation, which challenges us to find new exploitation formulas that would minimise the impact of these activities on game species. In order to do this, it is necessary to understand the multidimensional context in which those practices are involved in the region. They still have a strong relevance from a cultural and socio-economical point of view, in such a way that the mitigation of the ecological implications should be well planned, considering the various associated aspects.

It is evident that urgent measures are necessary for the wildlife fauna to be correctly managed in the Brazilian semi-arid region. Historically, hunting has had a strong impact on the population of some species in this region, and with their decline, the pressure has moved to other species of mammals, and to other local vertebrate animals. Ojasti (1997) emphasises that a reduction of hunting pressure seems to present the ideal conservation, and the strategic handling of the fauna, although, as pointed out by Alves et al. (2009a), this reduction is not feasible in many areas, mainly due to socioeconomic and cultural factors. As Coad et al. (2013) also point out, local wildlife management and planning for economic development and food security can gain much from considering the context within which hunters operate. Alves et al. (2009a), considering the game activities in Caatinga, said that the measures which aim to minimise the impact of hunting on animal populations are fundamental and urgent, and it is also important to include: a) educational development programmes about wildlife handling, with strong components in the environmental legislation and its correct application, and b) the creation of communication channels between the academic and governmental institution, and the populations involved in the hunting. We also believe that it is important to provide economic alternatives to hunters that depend on their hunting activity. Measures that aim to mitigate hunting motivated by existing conflict between wild mammals and the local human 
population are indispensable in protecting the animals affected by this, mainly the carnivores. In addition, external measures should be considered, such as controlling the illegal commerce of wild animals (Alves et al. 2009a), which is a persistent practice on the region, despite being prohibited by Brazilian environmental legislation.

It is important to note that the conservation of wild mammals in Caatinga goes far beyond the problems related to hunting activity, and that several factors contribute to mammal population losses. Caatinga's biodiversity has been affected by rudimentary agricultural and cattle ranching practices for more than 500 years, since colonisation in the sixteenth century (CoimbraFilho and Câmara 1996; Leal et al. 2005), nowadays it's considered an extremely threatened biome (Albuquerque et al. 2012; Oliveira et al. 2012). In this context, the conservation of the region's biodiversity depends on the local species' habitat maintenance. Urgent measures to mitigate this problem, include the creation of conservation units, as only $1 \%$ of Caatinga's territory is currently included within protected areas (Leal et al. 2005).

Combining biological with ethnobiological approaches is essential in planning broader hunting sustainability (Van Vliet and Nasi 2008). Considering the recent problems for biodiversity conservation in Caatinga, and that these have a direct and indirect effect on the local inhabitants, it is also evident that conservation strategies should consider the associated human needs, integrating cultural aspects of the local populations, and ecological aspects associated with the biodiversity of the region.

\section{ACKNOWLEDGMENTS}

We are grateful to Jessica Mohlman for the English review. We thank CNPq (Conselho Nacional de Desenvolvimento Científico e Tecnológico) for financial support (Edital Universal program $\mathrm{Nr}$ 476460/2012-3) and for a research fellowship granted to the first author. Anderson Feijó was supported by CAPES (Coordenação de Aperfeiçoamento de Pessoal de Nível Superior) and CNPq.

\section{REFERENCES}

1. $A b$ 'Saber AN (1974) 0 domínio semi-árido morfoclimático das caatingas brasileiras. Geomorfologia 43:1-26.

2. Albuquerque, Araújo $E$, Lima $A$, Souto $A$, Bezerra $B$, Freire EMX, Sampaio E, Casas FL, Moura G, Pereira G, Melo JG, Alves M, Rodal M, Schiel M, Neves RL, Alves RRN, AzevedoJúnior S,Telino Júnior W (2012) Caatinga revisited: ecology and conservation of an important seasonal dry forest. Scientific World Journal (2012):1-18. http://dx.doi.org/10.1100/2012/205182

3. Almeida CFCBR, Albuquerque UP (2002) Uso e conservação de plantas e animais medicinais no Estado de Pernambuco (Nordeste do Brasil): Um estudo de caso. Interciencia 27:276-285.

4. Alonso C, Faria DS, Langguth A, Santee DF (1987) Variação da pelagem na área de intergradação entre Callithrix jacchus e Callithrix penicillata. Revista Brasileira de Biologia 47:465-470.

5. Altrichter $M$, Boaglio G, Perovic $P(2006)$ The decline of jaguars Panthera onca in the Argentine Chaco. Oryx 40:302-309.

6. Alvard MS, Robinson JG, Redford KH, Kaplan H (1997) The Sustainability of Subsistence Hunting in the Neotropics. Conservation Biology 11:977-982.

7. Alves RRN (2009) Fauna used in popular medicine in Northeast Brazil. Journal of Ethnobiology and Ethnomedicine 5 (1):1-11.

8. Alves RRN (2012) Relationships between fauna and people and the role of ethnozoology in animal conservation. Ethnobiology and Conservation 1:1-69.

9. Alves RRN, Gonçalves MBR, Vieira WLS (2012a) Caça, uso e conservação de vertebrados no semiárido Brasileiro. Tropical Conservation Science 5:394-416.

10. Alves RRN, Lima HN, Tavares MC, Souto WMS, Barboza RRD, Vasconcellos A (2008) Animal-based remedies as complementary medicines in Santa Cruz do Capibaribe, Brazil. BMC Complementary and Alternative Medicine 8 (44): 1-9.

11. Alves RRN, Melo MF, Ferreira FS,Trovão DMBM, DiasTLP, Oliveira JV, Lucena RFP, Barboza RRD (2015) Healing with animals in a semiarid northeastern area of Brazil. Environment, Development and Sustainability in press:1-15. doi 10.1007/ s10668-015-9715-1

12. Alves RRN, Mendonça LET, Confessor MVA, Vieira WLS, Lopez LCS (2009a) Hunting strategies used in the semi-arid region of northeastern Brazil. Journal of Ethnobiology and Ethnomedicine $5(12): 1-16$

13. Alves RRN, Neto NAL, Brooks SE, Albuquerque UP (2009b) Commercialization of animal-derived remedies as complementary medicine in the semi-arid region of Northeastern Brazil. Journal of Ethnopharmacology 124:600608.

14. Alves RRN, Nogueira E, Araujo H, Brooks S (2010a) Bird-keeping in the Caatinga, NE Brazil. Human Ecology 38:147-156.

15. Alves RRN, Oliveira MGG, Barboza RRD, Lopez LCS (2010b) An ethnozoological survey of medicinal animals commercialized in the markets of Campina Grande, NE Brazil. Human Ecology Review 17:11-17

16. Alves RRN, Pereira Filho GA, Silva Vieira K, Souto WMS, Mendonças LET, Montenegro PFGP, Almeida WO, Vieira WLS (2012b) A zoological catalogue of hunted reptiles in the semiarid region of Brazil. Journal of Ethnobiology and Ethnomedicine 8 (27): 1-29. doi:10.1186/1746-4269-8-27.

17. Alves RRN, Pinto LCL, Barboza RRD, Souto WMS, Oliveira REMCC, Vieira WLS (2013a) A Global Overview of Carnivores 
Used in Traditional Medicines. In: Alves RRN, Rosa IL (eds) Animals in Traditional Folk Medicine: Implications for conservation. Springer, pp. 171-206.

18. Alves RRN, Rosa IL (2007a) Zootherapeutic practices among fishing communities in North and Northeast Brazil: A comparison. Journal of Ethnopharmacology 111:82-103.

19. Alves RRN, Rosa IL (2007b) Zootherapy goes to town: The use of animal-based remedies in urban areas of NE and N Brazil. Journal of Ethnopharmacology 113:541-555.

20. Alves RRN, Rosa IL (2010) Trade of animals used in Brazilian traditional medicine: trends and implications for conservation. Human Ecology 38:691-704.

21. Alves RRN, Rosa IL, Léo Neto NA, Voeks R (2012c) Animals for the Gods: Magical and Religious Faunal Use and Trade in Brazil. Human Ecology 40:751-780.

22. Alves RRN, Rosa IL, Santana GG (2007) The Role of Animalderived Remedies as Complementary Medicine in Brazil. BioScience 57: 949-955.

23. Alves RRN, Santana GG (2008) Use and commercialization of Podocnemis expansa (Schweiger 1812) (Testudines: Podocnemididae) for medicinal purposes in two communities in North of Brazil. Journal of Ethnobiology and Ethnomedicine 4(3): 1-6.

24. Alves RRN, Santana GG, Rosa IL (2013b) The Role of AnimalDerived Remedies as Complementary Medicine in Brazil. In: Alves RRN, Rosa IL (eds) Animals in traditional folk medicine: Implications for conservation. Springer Berlin Heidelberg, Berlin, pp. 289-301.

25. Alves RRN, SoutoWMS (2015) Ethnozoology: A Brief Introduction. Ethnobiology and Conservation 4:1-13.

26. Alves RRN, Souto WMS, Oliveira REMCC, Barboza RRD, Rosa IL (2013c) Aquatic Mammals Used in Traditional Folk Medicine: A Global Analysis. In: Alves RRN, Rosa IL (eds) Animals in Traditional Folk Medicine: Implications for Conservation. Springer, Heidelberg, pp. 241-261.

27. Alves RRN, Vieira KS, Santana GG, Vieira WLS, Almeida WO, Souto WMS, Montenegro PFGP, Pezzuti JCB (2012d) A review on human attitudes towards reptiles in Brazil. Environmental Monitoring and Assessment 184:6877-6901.

28. Anchieta J (1984) Cartas: Correspondência ativa e passiva. Loyola São Paulo.

29. Andrade-Lima D (1982) Present-day forest refuges in northeastern Brazil. In: Prance GT (ed) Biological diversification in the tropics. Columbia University Press, NewYork, pp. 245-251.

30. Andrade GO, Lins RC (1964) Introdução ao estudo dos" brejos" pernambucanos. Arquivos do ICT Instituto de Ciências da Terra 2:21-33.

31. Antonites A, Odendaal JSJ (2004) Ethics in human-animal relationships. Acta Veterinaria Brno 73:539-548.

32. Ayala G, Wallace RB (2010) Tapiridae. In: Wallace RB, Gómez H, Porcel ZR, Rumiz DI (eds) Distribución, ecología y conservación de los mamíferos medianos y grandes de Bolivia. Centro de Ecología Difusión, Fundación Simón I. Patiño, La Paz, pp. 555571.

33. Barbosa JAA, Nobrega VA, Alves RRN (2011) Hunting practices in the semiarid region of Brazil. Indian Journal of Traditional Knowledge 10:486-490.

34. Barboza RRD (2009) A Etnoecologia dos Tatus-peba Euphractus sexcinctus (Linnaeus, 1758) e Tatu-verdadeiro (Dasypus novemcinctus Linnaeus, 1758) na perspectiva dos povos do semi-árido paraibano. Dissertação Mestrado, UEPB, Campina Grande, Paraíba.

35. Barboza RRD (2013) Práticas cinegéticas e usos tradicionais da mastofauna por povos do semiárido nordestino. Tese de Doutorado. Universidade Federal da Paraíba.

36. Barboza RRD, Lopes SF, Souto WMS, Fernandes-Ferreira H, Alves RRN (2016) The role of game mammals as bushmeat In theCaatinga, northeast Brazil. Ecology and Society 21:1-11.

37. Barboza RRD, Mourão JS, Souto WMS, Alves RRN (2011) Knowledge and Strategies of Armadillo (Dasypus novemcinctus L. 1758 and Euphractus sexcinctus L. 1758) Hunters in the "Sertão Paraibano", Paraíba State, NE Brazil. Bioremediation, Biodiversity and Bioavailability 5 1-7.

38. Bertassoni A (2012) Perception and popular reports about giant anteaters (Myrmecophaga tridactyla Linnaeus, 1758) by two Brazilian traditional communities. Edentata 13:10-17.

39. Bigarella JJ, Andrade-Lima D, Riehs PJ ( 1975) Considerações a respeito das mudanças paleoambientais na distribuição de algumas espécies vegetais e animais no Brasil. Anais da Academia Brasileira de Ciências 47:411-464.

40. Black-Décima P, Rossi RV, Vogliotti A, Cartes JL, Maffei L, Duarte JMB, González S, Juliá JP (2010) Brown brocket deer Mazama gouazoubira (Fischer 1814). In: Duarte JMB, Gonzalez $S$ (eds) Neotropical Cervidology, Biology and Medicine of Latin American Deer. Funep/IUCN, 393p, pp. 190-201

41. Bodmer RE, Eisenberg JF, Redford KH (1997) Hunting and the Likelihood of Extinction of Amazonian Mammals. Conservation Biology 11:460-466.

42. Bodmer RE, Lozano EP (2001) Rural development and sustainable wildlife use in Peru. Conservation Biology 15:11631170.

43. Bonvicino CR, Oliveira JA, D'Andrea PS (2008) Guia dos roedores do Brasil, com chaves para gêneros baseadas em caracteres externos. Centro Pan-Americano de Febre Aftosa OPAS/OMS, Rio de Janeiro.

44. Borges-Nojosa DM, Caramaschi U (2003) Composição e análise comparativa da diversidade e das afinidades biogeográficas dos lagartos e anfisbenídeos (Squamata) dos Brejos Nordestinos. In: Leal IR, Tabarelli M, Silva JMC (eds) Ecologia e conservação da caatinga. Ministério do Meio Ambiente, Recife, pp. 463-512.

45. Brandão ML, Chame M, Cordeiro JLP, Chaves SAM (2009) Diversidade de helmintos intestinais em mamíferos silvestres e domésticos na Caatinga do Parque Nacional Serra da Capivara, Sudeste do Piauí, Brasil. Revista Brasileira de Parasitologia Veterinária 18:19-28.

46. Brown DE (1983) On the status of the jaguar in the Southwest. The Southwestern Naturalist 28:459-460.

47. Cardim F (1997) Tratados daTerra e Gente do Brasil. INCM,

48. Carmignotto AP, de Vivo M, Langguth A (2012) Mammals of the Cerrado and Caatinga: distribution patterns of the tropical open biomes of Central America. In: Patterson BD, Costa E (eds) Bones clones and biomes. Univ. of Chicago Press, Chicago, IL, pp. 307-350.

49. Carrillo E, Wong G, Cuarón AD (2000) Monitoring mammal populations in Costa Rican protected areas under different hunting restrictions. Conservation Biology 14:1580-1591.

50. Carter DC (1984) Perissodactylis. In: Anderson S, Jones JK (eds) Orders and families of recent mammals. Wiley, New York, pp. $549-562$. 
51. Cartes JL (2007) Patrones de uso de los mamiferos del Paraguay: importancia sociocultural y económica. In: Salas-Dueñas DA, Facetti JF (eds) Biodiversidad del Paraguay, una aproximación a sus realidades. Fundación Moisés Bertoni, USAID, GEF/BM, , Asunción, Paraguay, pp. 167-186.

52. Cavalcanti GN (2010) Biologia comportamental de Conepatus semistriatus (Carnivora, Mephitidae) em Cerrado do Brasil Central. MSc dissertation, Universidade Federal de Minas Gerais

53. Cerqueira R, Tribe CJ (2008) Genus Didelphis Linnaeus, 1758. In: Gardner AL (ed) Mammals of South America.: Marsupials, xenarthrans, shrews, and bats. The university of Chicago Press, Chicago, pp. 17-25.

54. Cheida CC, Nakano-Oliveira E, Fusco-Costa R, Rocha-Mendes F, Quadros J (2006) Ordem Carnivora. In: Reis NR, Peracchi AL, Pedro WA, Lima IP (eds) Mamíferos do Brasil. Universidade Estadual de Londrina, Londrina, Paraná, Brasil, pp. 231-276.

55. Chiarello AG (1999) Effects of fragmentation of the Atlantic forest on mammal communities in south-eastern Brazil. Biological Conservation 89:71-82.

56. Coad L, Schleicher J, Milner-Gulland EJ, Marthews TR, Starkey M, Manica A, Balmford A, MbombeW, Diop BineniTR, Abernethy KA (2013) Social and Ecological Change over a Decade in a Village Hunting System, Central Gabon. Conservation Biology 27:270-280.

57. Coimbra-Filho AF, Câmara IG (1996) Os limites originais do bioma Mata Atlântica na região Nordeste do Brasil. Fundação Brasileira para Conservação da Natureza Rio de Janeiro.

58. Confessor MVA, Mendonca LET, Mourao JS, Alves RRN (2009) Animals to heal animals: ethnoveterinary practices in semiarid region, Northeastern Brazil. Journal of Ethnobiology and Ethnomedicine 5 (37): 1-9.

59. Conforti VA, Cesar CAF (2003) Local perceptions of jaguars Panthera onca and pumas Puma concolor in the Iguaçu National Park area, south Brazil. Biological Conservation 111:215-221.

60. Conover MR (2002) Resolving human-wildlife conflicts: the science of wildlife damage management. Lewis Publishers, Boca Raton, FL.

61. Costa FAM, Reis RC, Benevides F, Tomé GS, Holanda MA (2001) Coccidioidomicose pulmonar em caçador de tatus. J Pneumol 27:275-278.

62. Costa RC, Araújo FS, Lima-Verde LW (2007) Flora and life-form spectrum in an area of deciduous thorn woodland (caatinga) in northeastern, Brazil. Journal of Arid Environments 68:237-247.

63. Cowie $H$ (2011) Sloth bones and anteater tongues: Collecting American nature in the Hispanic world (1750-1808). Atlantic Studies 8:5-27.

64. Crockett CM (1998) Conservation biology of the genus Alouatta. International Journal of Primatology 19:549-578.

65. Currier MJ (1983) Puma concolor. Mammalian species 200:1-7.

66. Dantas ARC, Menezes FH, Serra KS, Barbosa EDO, FernandesFerreira H (2016) First record of Sylvilagus brasiliensis (Linnaeus, 1758) (Lagomorpha: Leporidae) in Rio Grande do Norte state, Northeast Brazil. Check List 12:1-4.

67. DeMattia EA, Curran LM, Rathcke BJ (2004) Effects of small rodents and large mammals on Neotropical seeds. Ecology 85:2161-2170.

68. Desbiez ALJ, Keuroghlian A, Beisiegel B, Medici EP, Gatti A, Pontes ARM, Campos CB, Tófoli CF, Moraes Júnior EA, Azevedo
FC (2012) Avaliação do risco de extinção do cateto Pecari tajacu Linnaeus, 1758, no Brasil. Biodiversidade Brasileira, 74-83.

69. Diersing VE (1981) Systematic status of Sylvilagus brasiliensis and $\boldsymbol{S}$. insonus from North America. Journal of Mammalogy, 539-556.

70. Dirzo R, Miranda A (1990) Contemporary Neotropical Defaunation and Forest Structure, Function, and Diversity-A Sequel to John Terborg. Conservation Biology 4:444-447.

71. Eisenberg JF, Redford KH (1999) Mammals of the neotropics. University of Chicago Press, Chicago, Illinois.

72. Emmons L, Feer F (1997) Neotropical rainforest mammals: a field guide. University of Chicago Press, Chicago.

73. Eulálio KD, Macedo RL, Cavalcanti MAS, Martins LMS, Santos LM, Wanke B (2001) Coccidioides immitis isolated from armadillos (Dasypus novemcinctus) in the state of Piauí, northeast Brazil. Mycopathologia 149:57-61.

74. Facure KG, Monteiro-Filho ELA (1996) Feeding habits of the crab- eating fox, Cerdocyon thous (Carnivora, Canidae), in a suburban area of southeastern Brazil. Mammalia 60:147-149.

75. Feijó A, Langguth A (2013) Mamíferos de Médio e Grande Porte do Nordeste do Brasil: Diversidade e Taxonomia, com descrição de novas espécies. Revista Nordestina de Biologia 22:3-227.

76. Feijó A, Garbino GST, Campos BATP, Rocha PA, Ferrari SF, Langguth, A. (2015) Distribution of Tolypeutes Illiger, 1811 (Xenarthra: Cingulata) with Comments on Its Biogeography and Conservation. Zoological Science 32: 77-87.

77. Fernades-Ferreira $H$ (2011) Atividades cinegéticas em um brejo de Altitude no Nordeste do Brasil: Etnozoologia e conservação. Dissertação de Mestrado, Universidade Federal da Paraíba, João Pessoa.

78. Fernades-Ferreira H (2014) A caça no Brasil: Panorama histórico e atual.Tese de doutorado, Universidade Federal da Paraíba.

79. Fernandes-Ferreira $H$, Alves RRN (2014) Legislação e mídia envolvendo a caça de animais silvestres no Brasil: uma perspectiva histórica e socioambiental. Revista Gaia Scientia 8:1-7.

80. Fernandes-Ferreira $\mathrm{H}$, Mendonça SV, Albano C, Ferreira FS, Alves RRN (2012) Hunting, use and conservation of birds in Northeast Brazil. Biodiversity and Conservation 21 (1): 221-244.

81. Fernandes-Ferreira H, Mendonca SV, Cruz RL, Borges-Nojosa DM, Alves RRN (2013) Hunting of herpetofauna in montane, coastal, and dryland areas of Northeastern Brazil. Herpetological Conservation and Biology 8:652-666.

82. Ferreira FS, Albuquerque UP, Coutinho HDM, Almeida WO, Alves RRN (2012) The Trade in Medicinal Animals in Northeastern Brazil. Evidence-based Complementary and Alternative Medicine 2012:1-20.

83. Ferreira FS, Brito S, Ribeiro S, Almeida W, Alves RRN (2009a) Zootherapeutics utilized by residents of the community Poco Dantas, Crato-CE, Brazil. Journal of Ethnobiology and Ethnomedicine 5 (21): 1-10.

84. Ferreira FS, Brito S, Ribeiro S, Saraiva A, Almeida W, Alves RRN (2009b) Animal-based folk remedies sold in public markets in Crato and Juazeiro do Norte, Ceara, Brazil. BMC Complementary and Alternative Medicine 9 (17): 1-8.

85. Ferreira FS, Fernandes-Ferreira $\mathrm{H}$, Leo Neto N, Brito SV, Alves RRN (2013)The trade of medicinal animals in Brazil: current status and perspectives. Biodiversity and Conservation 22:839870 . 
86. Fonseca GAB, Herrman G, LeiteYLR, Mittermeier RAM, Rylands $A B$, Patton JL (1996) Lista anotada dos mamíferos do Brasil. Occasional Papers in Conservation Biology, Conservation International/Fundação Biodiversitas, Washington, DC.

87. Fonseca GAB, Robinson JG (1990) Forest size and structure: competitive and predatory effects on small mammal communities. Biological Conservation 53:265-294.

88. Fusari A, Carpaneto G (2006) Subsistence hunting and conservation issues in the game reserve of Gile, Mozambique. Biodiversity and Conservation 15:2477-2495.

89. Gândavo PM (1858) Historia da provincial Santa Cruz, a que vulgarmente chamamos Brasil. Academia Real das Sciencias, Lisboa.

90. Garcia-Alaniz N, Naranjo EJ, Mallory FF (2010) Human-Felid Interactions in Three Mestizo Communities of the Selva Lacandona, Chiapas, Mexico: Benefits, Conflicts and Traditional Uses of Species. Human Ecology 38:451-457.

91. Gardner AL (2008) Magnorder Xenarthra. In: Gardner AL (ed) Mammals of South America Vol 1. Marsupials, Xenarthrans, Shrews and Bats. The University of Chicago Press, Chicago, pp. 127-176.

92. Graham K, Beckerman AP, Thirgood S (2005) Human-predatorprey conflicts: ecological correlates, prey losses and patterns of management. Biological Conservation 122:159-171.

93. Gregorin $R$ (2006)Taxonomia e variação geográfica das espécies do gênero Alouatta Lacépède (Primates, Atelidae) no Brasil. Revista Brasileira de Zoologia 23:64-144.

94. Grompper ME, Decker DM (1998) Nasua nasua. Mammalian species $580: 1-9$.

95. Grubb P, Groves CP (1993) The Neotropical Peccaries Dicotylidae:Tayassu and Catagonus. In: Oliver WLR (ed) Status Survey andConservation Action Plan - Pigs, Peccaries and Hippos. IUCN, Cambrigde and Gland, pp. 5-7.

96. Guedes PG, Borges-Nojosa DM, Silva JAG, Salles LO (2000) Novos registros de Alouatta no estado do Ceará (Primates, Atelidae). Neotropical Primates 8:29-30.

97. Gurgel-Filho NM, Feijó A, Langguth A (2015) Pequenos Mamíferos do Ceará (Marsupiais, Morcegos e roedores Sigmodontíneos) com Discussão Taxonômica de Algumas espécies. Revista Nordestina de Biologia 23:3-150.

98. Hanazaki N, Alves RRN, Begossi A (2009) Hunting and use of terrestrial fauna used by Caicaras from the Atlantic Forest coast (Brazil). Journal of Ethnobiology and Ethnomedicine 5 (36): 1-8.

99. Happold DCD (1995) The interactions between humans and mammals in Africa in relation to conservation: a review. Biodiversity and Conservation 4:395-414.

100. HausserY, Weber H, Meyer B (2009) Bees, farmers, tourists and hunters: conflict dynamics around Western Tanzania protected areas. Biodiversity and Conservation 18:2679-2703.

101. Henle K, Lindenmayer DB, Margules CR, Saunders DA, Wissel C (2004) Species survival in fragmented landscapes: where are we now? Biodiversity and Conservation 13:1-8.

102. Hill K, Padwe J (2000) Sustainability of Aché hunting in the Mbaracayu reserve, Paraguay. In: Robinson JG, Bennett EL (eds) Hunting for sustainability in Tropical Forests. Columbia University Press, New York, pp. 79-105.

103. Hirsch A (2010) Mapa adaptado do Banco de Dados Georreferenciados das Localidades de Ocorrência de Primatas Brasileiros (BDGEOPRIM) [http://www.icb.ufmg.br/zoo/ primatas/home_bdgeoprim.htm].
104. Ho J (2005) Information Resources on Human-Animal Relationships Past and Present. AWIC Resource Series.

105. Husson AM (1978) The mammals of Suriname. Zoologische Monographieen Rijksmuseum Natuurlijke Historie Leiden. J.E.Brill, Leiden.

106. lack-Ximenes GE (1999) Sistemática da família Dasyproctidae Bonaparte, 1838 (Rodentia, Hystricognathi) no Brasil. Universidade de São Paulo, São Paulo.

107. Inskip C, Zimmermann A (2009) Human-felid conflict: a review of patterns and priorities worldwide. Oryx 43:18-34.

108. IUCN (2015) IUCN 2015. IUCN Red List of Threatened Species. Version 2015.2. [www.iucnredlist.org]

109. Jácomo ATA, Furtado MM, Kashivakura CK, Marinho-Filho J, Sollmann R, Tôrres NM, Silveira L (2013) White-lipped peccary home-range size in a protected area and farmland in the central Brazilian grasslands. Journal of Mammalogy 94:137-145.

110. Johnson WE, Eizirik E, Lento GM (2001) The control, exploitationand conservation of carnivores. In: Gittleman JL, Funk S,MacDonald DW, Wayne RK (eds) Carnivore conservation. Cambridge University Press, Cambridge, pp. 196-220.

111. Kideghesho $\mathrm{J}$ (2008) Co-existence between the traditional societies and wildlife in western Serengeti, Tanzania: its relevancy in contemporary wildlife conservation efforts. Biodiversity and Conservation 17:1861-1881.

112. Klink CA, Machado RB (2005) Conservation of the Brazilian cerrado. Conservation Biology 19:707-713.

113. Langguth A (1969) Die Sudamerikanischem Canidae Unter Besonderer Berucksichtigung Des Manhnenwolfes Chrysocyon brachyurus. Zeitschrift für Wissenschaftliche Zoologie 179: 1-188.

114. Langguth A (1975) Ecology and evolution in the South American canids. In: Fox MW (ed) The Wild Canids: their systematics, behavioral ecology, and evolution. Van Nostrand Reinhold Co., NewYork, pp. 192-206.

115. Leal IR, Silva JMC, Tabarelli M, Lacher-Jr. TE (2005) Mudando o curso da conservação da biodiversidade na Caatinga do Nordeste do Brasil. Megadiversidade 1:139-146.

116. Leopold AS (1959) Wildlife of Mexico: the game birds and mammals. Univ of California Press, Berkeley and Los Angeles.

117. Léry J ( 1997) Viagem à terra do Brasil. Itatiaia Belo Horizonte.

118. Lins RC (1989) As áreas de exceção do agreste de Pernambuco. Sudene Recife.

119. Lisboa $P$ (2002) Natureza, homem e manejo de recursos naturais na região de Caxiuanã, Melgaço, Pará. MPEG, Belém.

120. Lopes MA, Ferrari SF (2000) Effects of Human Colonization on the Abundance and Diversity of Mammals in Eastern Brazilian Amazonia. Conservation Biology 14:1658-1665.

121. Mares MA, Willig MR, Lacher-Jr.TE (1985)The Brazilian Caatinga in South American Zoogeography: Tropical Mammals in a Dry Region. Journal of Biogeography 12:57-69.

122. Mares MA, Willig MR, Streilein KE, Lacher TE (1981) The mammals of northeastern Brazil: a preliminary assessment. 50:81-137.

123. Marques ELN, Beltrão RM, Ferrari SF (2013) Primates, Pitheciidae, Callicebus barbarabrownae Hershkovitz, 1990: New localities for the critically endangered titi monkey in the São Francisco basin, state of Sergipe, Brazil. Check List 9:113-115. 
124. Marshall K, White R, Fischer A (2007) Conflicts between humans over wildlife management: on the diversity of stakeholder attitudes and implications for conflict management. Biodiversity and Conservation 16:3129-3146.

125. Mayer J, Wetzel R (1987) Tayassu pecari. Mammalian species 293:1-7.

126. Melo FP, Siqueira JA, Santos BA, Álvares-da-Silva O, Ceballos G, Bernard E (2014a) Football and Biodiversity Conservation: FIFA and Brazil Can Still Hit a Green Goal. Biotropica 46:257- 259.

127. Melo RS, Silva OC, Souto A, Alves RRN, Schiel N (2014b) The role of mammals in local communities living in conservation areas in the Northeast of Brazil: an ethnozoological approach. Tropical Conservation Science 7:423-439.

128. Mena PV, Stallings JR, Regalado JB, Cueva RL (2000) The sustainability of current hunting practices by the Huaorani. In: Robinson JG, Bennett E (eds) Hunting for sustainability in Tropical Forests. Columbia University Press, New York, USA, NewYork, pp. 57-78.

129. Mendonça LET, Souto CM, Andrelino LL, Souto WMS, Vieira WLS, Alves RRN (2011) Conflitos entre pessoas e animais silvestres no semiárido paraibano e suas implicações para conservação. Sitientibus Série Ciências Biológicas 11:185-199.

130. Mendonça LET, Vasconcellos A, Souto CM, Oliveira TPR, Alves RRN (2015) Bushmeat consumption and its implications for wildlife conservation in the semi-arid region of Brazil. Regional Environmental Change 16:1649-1657.

131. Meritt D (2008) Xenarthrans of the Paraguayan Chaco. In: Vizcaíno SF, Loughry WJ (eds) The biology of the Xenarthra. University Press of Florida, Gainesville, pp. 294-299.

132. Meserve $P$ (2007) Zoogeography of South America. In: Orme A (ed) Physical geography of South America. Oxford University Press, Oxford, pp. 112-132.

133. Mesquita GP, Barreto GP (2015) Evaluation of mammals hunting in indigenous and rural localities in Eastern Brazilian Amazon. Ethnobiology and Conservation 4:1-14.

134. Michalski F, Boulhosa RLP, Faria A, Peres C (2006) Humanwildlife conflicts in a fragmented Amazonian forest landscape: determinants of large felid depredation on livestock. Animal Conservation 9:179-188.

135. Michalski F, Peres CA (2007) Disturbance-mediated mammal persistence and abundance-area relationships in Amazonian forest fragments. Conservation Biology 21:1626-1640.

136. Ministério do Meio Ambiente (2014) Lista das Espécies da Fauna Brasileira Ameaçadas de Extinção. Portaria 444, de 17 de dezembro de 2014.

137. Modercin IF (2010) Rancho do jatobá do meio do mundo: etnografia da agricultura pankararé e a relação dos índios com o ambiente. Master Science, Universidade Federal da Bahia.

138. Mones A, Ojasti J (1986) Hydrochoerus hydrochaeris. Mammalian species 264:1-7.

139. Monks GG (2005) The exploitation and cultural importance of sea mammals. Oxbow Books.

140. Monroy-Vilchis O, Cabrera L, Suárez P, Zarco-González MM, Rodríguez-Soto C, Urios V (2008) Uso tradicional de vertebrados silvestres en la Sierra Nanchititla, México. Interciencia 33:308313.

141. Moura FBP, Marques JGW (2008) Zooterapia popular na Chapada Diamantina: uma Medicina incidental? Ciência \& Saúde Coletiva 13:2179-2188.
142. Moura SG, Pessoa FB, Oliveira FF, Lustosa AHM, Soares CB (2012) Animais silvestres recebidos pelo centro de triagem do ibama no Piauí no ano de 2011. Enciclopédia Biosfera 8:1-15.

143 Mourão JS, Araujo HFP, Almeida FS (2006) Ethnotaxonomy of mastofauna as practised by hunters of the municipality of Paulista, state of Paraíba-Brazil. Journal of Ethnobiology and Ethnomedicine 2 (19): 1-7.

144. Murray JL, Gardner GL (1997) Leopardus pardalis. Mammalian species 558:1-10.

145. Myers N, Mittermeier RA, Mittermeier CG, Fonseca GAB, Kent J (2000) Biodiversity hotspots for conservation priorities. Nature 403:853-858.

146. Naughton-Treves L, Mena JL, Treves A, Alvarez N, Radeloff VC (2003) Wildlife Survival Beyond Park Boundaries: the Impact of Slash-and-Burn Agriculture and Hunting on Mammals in Tambopata, Peru. Conservation Biology 17:1106-1117.

147. Neris N, Colman F, Ovelar E, Sukigara N, Ishii N (2002) Guía de mamíferos medianos y grandes del Paraguay: distribución, tendencia poblacional y utilización. SEAM, Asunción, Paraguay.

148. Noss RF, Quigley HB, Hornocker MG, MerrillT, Paquet PC (1996) Conservation biology and carnivore conservation in the Rocky Mountains. Conservation Biology 10:949-963.

149. Nowak RM (1991) Walker's Mammals of the World. Johns Hopkins, Baltimore.

150. Ojasti $J(1984)$ Hunting and conservation of mammals in Latin America. Acta Zoologica Fennica 172:177-181.

151. Ojasti $J(1997)$ Wildlife utilization in Latin America: current situation and prospects for sustainable management. Food and Agriculture Organization of the United Nations, Rome.

152. Ojasti J (2000) Manejo de Fauna Silvestre Neotropical. In: Dallmeier F (ed) SI/MAB Series. Smithsonian Institution/MAB Biodiversity Program, Washington D.C., pp. 290.

153. Oliveira FF, Langguth A (2004) Pequenos mamíferos (Didelphimorphia e Rodentia) de Paraíba e Pernambuco, Brasil. Revista Nordestina de Biologia 18:19-85.

154. Oliveira G, Araújo MB, Rangel TF, Alagador D, Diniz-Filho JAF (2012) Conserving the Brazilian semiarid (Caatinga) biome under climate change. Biodiversity and Conservation 21:29132926.

155. Oliveira JA, Gonçalves PR, Bonvicino CR (2003) Mamíferos da Caatinga. In: Leal IR, Tabarelli M, Silva JMC (eds) Ecologia e conservação da caatinga. 1 ed. Ed. Universitária da UFPE, Recife, Brasil, pp. 275-336.

156. OliveiraTG (1998) Leopardus wiedii. Mammalian species 579:16.

157. Osburn $\mathrm{BI}$ (1994) Bluetongue virus. The Veterinary clinics of North America. Food animal practice 10:547-560.

158. Palmeira FBL, BarrellaW (2007) Conflitos causados pela predação de rebanhos domésticos por grandes felinos em comunidades quilombolas na Mata Atlântica. Biota Neotropica 7:119-128.

159. Palmeira FBL, Crawshaw Jr PG, Haddad CM, Ferraz KMPMB, Verdade LM (2008) Cattle depredation by puma Puma concolor and jaguar Panthera onca in central-western Brazil. Biological Conservation 141:118-125.

160. Papavero N, Teixeira DM, Chiqueri A (2011) As Adnotationes" do Jesuíta Johann Breuer sobre a história natural da missão de Ibiapaba, Ceará (1789). Arquivos de Zoologia 42:133-159. 
161. Peixoto AL (2006) Enciclopédia Agrícola Brasileira. Editora da Universidade de São Paulo, São Paulo.

162. Pereira Filho GA, Montingelli GG (2011) Check list of snakes from the Brejos de Altitude of Paraíba and Pernambuco, Brazil. Biota Neotropica 11:145-151.

163. Pereira JPR, Schiavetti A (2010) Conhecimentos e usos da fauna cinegética pelos caçadores indígenas "Tupinambá de Olivença" (Bahia). Biota Neotropica 10:175-183.

164. Peres $C$, Nascimento $H(2006)$ Impact of game hunting by the Kayapó of south-eastern Amazonia: implications for wildlife conservation in tropical forest indigenous reserves. Biodiversity and Conservation 15:2627-2653.

165. Peres CA (1997) Effects of habitat quality and hunting pressure on arboreal folivore densities in neotropical forests: a case study of howler monkeys (Alouatta spp.). Folia Primatologica 68:199-222.

166. Peres CA (2001) Synergistic Effects of Subsistence Hunting and Habitat Fragmentation on Amazonian Forest Vertebrates. Conservation Biology 15:1490-1505.

167. Perrin WF, Wursig B, Thewissen JGM (2008) Encyclopedia of marine mammals. Academic Press, San Diego.

168. Piso W, Marcgrave G (1648) Historia Naturalis Brasiliae: in qua non tantum plantæ et animalia, sed et ind igenarum morbi, ingenia et mores describuntur et iconibus supra quingentas illustrantur. Elzevier, Amsterdam.

169. Polisar J, Maxit I, Scognamillo D, Farrell L, Sunquist ME, Eisenberg JF (2003) Jaguars, pumas, their prey base, and cattle ranching: ecological interpretations of a management problem. Biological Conservation 109:297-310.

170. Prance GT (1987) Vegetation. In: Whitmore TC, Prance GT (eds) Biogeography and Quaternary history in tropical America.Oxford Science Publications, Oxford, United Kingdom, pp. 28-45.

171. Redford KH (1994)The Edentates of the Cerrado. Edentata 1 4-10.

172. Redford KH, Ray JC, Boitani L (2011) Mapping and navigating mammalian conservation: from analysis to action. Philosophical Transactions of the Royal Society B: Biological Sciences 366:2712-2721.

173. Redford KH, Robinson JG (1991) Subsistence and commercial uses of wildlife in Latin America. In: Robinson JG, Redford KH (eds) Neotropical wildlife use and conservation. pp. 6-23.

174. Redford KH, Wetzel RM (1985) Euphractus sexcinctus. Mammalian species 252: 1-4.

175. Renctas (2001) $1^{\circ}$ relatório nacional sobre o tráfico de fauna silvestre. Brasília.

176. Ripple J, Perrine D (1999) Manatees and dugongs of the world. Voyageur Press

177. Robinson JG, Bodmer RE (1999) Towards Wildlife Management inTropical Forests. The Journal of Wildlife Management 63:1-13.

178. Robinson JG, Redford KH (1991) Neotropical wildlife use and conservation. University of Chicago Press, Chicago.

179. Rocha VJ, Reis NR, Sekiama ML (2004) Dieta e dispersão de sementes por Cerdocyon thous (Linnaeus)(Carnivora, Canidae), em um fragmento florestal no Paraná, Brasil. Revista Brasileira de Zoologia 21:871-876.

180. Rodrigues MT (1996) Lizards, snakes, and amphisbaenians from the quaternary sand dunes of the middle Rio São Francisco, Bahia, Brazil. Journal of Herpetology 30:513-523.
181. Rossi RV, Bianconi GV, PedroWA (2006) Ordem Didelphimorphia. In: Reis NR, Peracchi AL, Pedro WA, Lima IP (eds) Mamíferos do Brasil. 1 ed. Universidade Estadual de Londrina, Londrina, Paraná, Brasil, pp. 27-66.

182. Ruiz-Miranda CR, Affonso AG, Martins A, Beck B (2000) Distribuição do sagüi (Callithrix jacchus) nas áreas de ocorrência do mico-leão-dourado (Leontopithecus rosalia) no estado do Rio de Janeiro. Neotropical Primates 8:98-101.

183. Rylands AB, Coimbra-Filho AF, Mittermeier RA (2009) The systematics and distributions of the marmosets (Callithrix, Callibella, Cebuella, and Mico) and callimico (Callimico) (Callitrichidae, Primates). In: Ford SM, Porter LM, Davis LC (eds) The smallest Anthropoids. The Marmose/Callimico Radiation. Springer, Chicago, pp. 25-62.

184. Sampaio EVSB (1995) Overview of the Brazilian caatinga. In: Bullock SH, Mooney HA, Medina E (eds) Seasonally DryTropical Forests. Cambridge University Press, Cambridge, UK, pp. 35-58.

185. Sampaio JA, Castro MS, Silva FO (2009) Uso da cera de abelhas pelos índios Pankararé no Raso da Catarina, Bahia, Brasil. Arquivos do Museu Nacional 67:3-12.

186. Santos IB, Fonseca GAB, Rigueira S, Machado RB (1994) The rediscovery of the Brazilian three banded armadillo and notes on its conservation status. Edentata 1:11-15.

187. Seymour KL (1989) Panthera onca. Mammalian species 340:1-9.

188. Shaw JH, CarterTS (1980) Giant anteaters - getting too close to this toothless creature could result in a fatal embrace. Natural History 89: 62-67.

189. Silva-Júnior JS, Nunes AP (2001) The disjunct geographical distribution of the yellow-armadillo, Euphractus sexcinctus (Xenarthra, Dasypodidae). Edentata 4:16-18.

190. Silva-Júnior JS, Oliveira JA, Dias PA, Oliveira TGD (2005) Update on the geographical distribution and habitat of the tapiti (Sylvilagus brasiliensis: Lagomorpha, Leporidae) in the Brazilian Amazon. Mammalia 69:245-250.

191. Silva E, Rosa P, Arruda M, Rúbio E (2005) Determination of duffy phenotype of red blood cells in Dasypus novemcinctus and Cabassous sp. Brazilian Journal of Biology 65:555-557.

192. Silva JMC, Oren DC (1993) Observations on the habitat and distribution of the Brazilian three-banded armadillo Tolypeutes tricinctus, a threatened Caatinga endemic. Mammalia 57:149152.

193. Silva JMC, Souza MA, Bieber AGD, Carlos CJ (2003) Aves da Caatinga: Status, uso do habitat e sensitividade. In: Leal IR, Tabarelli M, Silva JMC (eds) Ecologia e conservação da caatinga. 1 ed. Ed. Universitária da UFPE, Recife, Brasil, pp. 237-274.

194. Silvius KM, Bodmer RE, Fragoso JMV (2004) People in nature: wildlife conservation in South and Central America. Columbia University Press.

195. Souto WMS (2014) Atividades cinegéticas, usos locais e tradicionais da fauna por povos do semiárido paraibano. Tese de doutorado. Universidade Federal da Paraíba.

196. SoutoWMS, Mourão JS, Barboza RRD, Alves RRN (2011) Parallels between zootherapeutic practices in Ethnoveterinaryand Human Complementary Medicine in NE Brazil. Journal ofEthnopharmacology 134:753-767.

197. Souza JB, Alves RRN (2014) Hunting and wildlife use in an Atlantic Forest remnant of northeastern Brazil. Tropical Conservation Science 7:145-160.

198. Staden H (1974) Duas viagens ao Brasil. Itatiaia, Belo Horizonte. 
199. Streilein KE (1982) The ecology of small mammals in the semiarid Brazilian Caatinga. IV. Habitat selection. Annals of Carnegie Museum 51:331-343.

200. Superina M, Abba AM (2010) Tolypeutes tricinctus. In: IUCN 2013. IUCN Red List of Threatened Species. Version 2013.1. [www.iucnredlist.org]

201. Superina M, Abba AM (2010) Priodontes maximus. [www. iucnredlist.org]

202. Tabarelli M, Santos AMM (2004) Uma breve descrição sobre a história natural dos Brejos Nordestinos. In: Porto KC, Cabral JJP, Tabarelli M (eds) Brejos de Altitude em Pernambuco e Paraíba, História Natural, Ecologia e Conservação. Ministério do Meio Ambiente, Brasília, pp. 17-24.

203. Terborgh J (1988) The big things that run the world-a sequel to EOWilson. Conservation Biology 2:402-403.

204. Terborgh J, Lopez L, Nunez P, Rao M, Shahabuddin G, Orihuela G, Riveros M, Ascanio R, Adler GH, LambertTD (2001) Ecological meltdown in predator-free forest fragments. Science 294:19231926.

205. Terborgh J, Winter B (1980) Some causes of extinction. Conservation Biology 2:119-133.

206. Theulen V (2004) Conservação dos Brejos de Altitude no Estado de Pernambuco. In: Porto KC, Cabral JJP, Tabarelli M (eds) Brejos de Altitude em Pernambuco e Paraíba, História Natural, Ecologia e Conservação. Ministério do Meio Ambiente, Brasília, pp. $299-230$

207. Thevet A (1978) Singularidades da França Antártica. Itatiaia, Belo Horizonte.

208. Torres DF, Oliveira ES, Alves RRN, Vasconcellos A (2009) Etnobotânica e Etnozoologia em Unidades de Conservação: Usoda biodiversidade na Apa de Genipabu, Rio Grande do Norte, Brasil. Interciencia 34:623-629.

209. Treves A, Wallace RB, Naughton-Treves L, Morales A (2006) Co-managing human-wildlife conflicts: a review. Human Dimensions of Wildlife 11:383-396.

210. Trinca CT, Ferrari SF (2006) Caça em assentamento rural na amazônia matogrossense. Diálogos em ambiente e sociedade no Brasil. ANPPAS, Annablume, Indaiatuba, pp. 155-167.

211. Uribe J, Arita HT (1998) Distribución, diversidad y conservación de los mamíferos de importancia cinegética en México. Acta Zoologica Mexicana 75: 47-71.

212. Valle YBM (2007) Vaqueiros do Sítio do Meio (Lagoa Grande/ PE) \& Mamíferos Nativos das Caatingas Pernambucanas: Percepções e Interações. MSc. Thesis, Universidade Federal de Pernambuco,Recife, Brazil.

213. vanVliet N, Mesa MPQ, Cruz-Antia D, Aquino LJN, Moreno J, Nasi R (2014) The uncovered volumes of bushmeat commercializedin the Amazonian trifrontier between Colombia, Peru \& Brazil. Ethnobiology and Conservation 3:1-11. http:// dx.doi.org/10.15451/ec2014-11-3.7-1-11

214. Van Vliet N, Nasi R (2008) Hunting for livelihood in northeast Gabon: patterns, evolution, and sustainability. Ecology and Society 13(2):33. http://www.ecologyandsociety.org/vol13/iss2/ art33/

215. van Vliet N, Quiceno-Mesa MP, Cruz-Antia D, Tellez L, Martins C, Haiden E, Oliveira MR, Adams C, Morsello C, Valencia L (2015) From fish and bushmeat to chicken nuggets: the nutrition transition in a continuum from rural to urban settings in the Tri frontier Amazon region. Ethnobiology and Conservation 4:1-12. http://dx.doi.org/10.15451/ec2015-7-4.6-1-12
216. Vanzolini PE, Ramos-Costa AMM, Vitt LJ (1980) Répteis das caatingas. Academia Brasileira de Ciências, Rio de Janeiro.

217. Varela DM, Trovati RG, Guzmán KR, Rossi RV, Duarte JMB (2010) Red Brocket Deer - Mazama americana. In: Duarte JMB, GonzalezS (eds) Neotropical cervidology, biology and medicine of Latin American deer. Funep/IUCN, pp. 151-159.

218. Vargas LMA (2002) Estudio comparativo de la caza y uso de mamiferos en dos comunidades Tsimane' Provincia Ballivián Beni. Universidad Mayor de San Andrés, La Paz.

219. Vasconcelos-Neto CFA (2013) Utilização de Recursos Faunísticos por Caçadores do Município de Lagoa-PB (Nordeste/Brasil). Monografia de Graduação, Universidade Federal da Paraíba.

220. Vázquez LB, Gaston KJ (2006) People and mammals in Mexico: conservation conflicts at a national scale. Biodiversity and Conservation 15:2397-2414.

221. Veiga $L M$, Printes $R C$, Rylands $A B$, Kierulff $C M$, Oliveira $M M$, Mendes SL (2008) Callicebus barbarabrownae. In: The IUCN Red List of Threatened Species 2008: e.T39929A10291470. Downloaded on 21 May 2016.

222. Veloso HP, Rangel-Filho ALR, Lima JCA (1991) Classificação da vegetação brasileira, adaptada a um sistema universal. Ministério da Economia, Fazenda e Planejamento, Fundação Instituto Brasileiro de Geografia e Estatística, Diretoria de Geociências, Departamento de Recursos Naturais e Estudos Ambientais.

223. Vieira GG (2009) Desertificação e convivência com o semiárido brasileiro: da casa de adobe e do mocó à agroecologia e permacultura na região de Gilbués, Piauí. OKARA: Geografia em debate 3:23-53.

224. Vieira WLS, Santana GG, Arzabe C (2009) Diversity of reproductive modes in anurans communities in the Caatinga (dryland) of northeastern Brazil. Biodiversity and Conservation 18:55-66.

225. Voss RS (2011) Revisionary notes on Neotropical porcupines (Rodentia: Erethizontidae). 3. An Annotated Checklist of the Species of Coendou Lacepede, 1799. American Museum Novitates 3720:1-36.

226. Wetzel RM, Gardner AL, Redford KH, Eisenberg JF (2008) Order Cingulata. In: Gardner AL (ed) Mammals of South America. Volume 1: Marsupials, Xenarthrans, Shrews and Bats. University of Chicago Press, pp. 128-156.

227. Wilson DE, Reeder DM (2005) Mammal species of the world, a taxonomic and geographic reference. Third ed. The Johns Hopkins University Press, Baltimore.

228. Yensen E,TarifaT (2003) Galictis cuja Mammalian Species 728 : $1-8$.

229. Young SP (1946)The Puma, Mysterious American Cat. In:Young SP, Goldman EA (eds) History, Life Habits, Economic Status, and Control, Part I. The American Wildlife Institute, Washington, D.C, pp. 1-176.

230. Zimmermann A, Walpole MJ, Leader-Williams N (2005) Cattle ranchers' attitudes to conflicts with jaguars in the Pantanal of Brazil. Oryx 39:1-7.

Received: 03 January 2016

Accepted: 01 July 2016

Published: 27 July 2016 